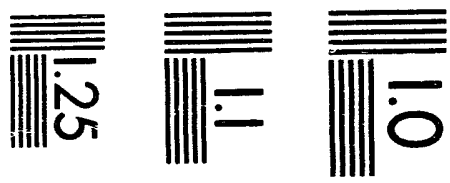

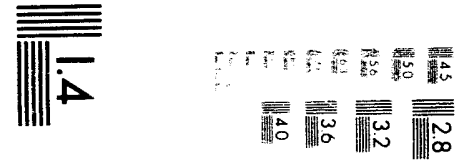

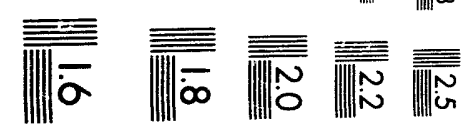



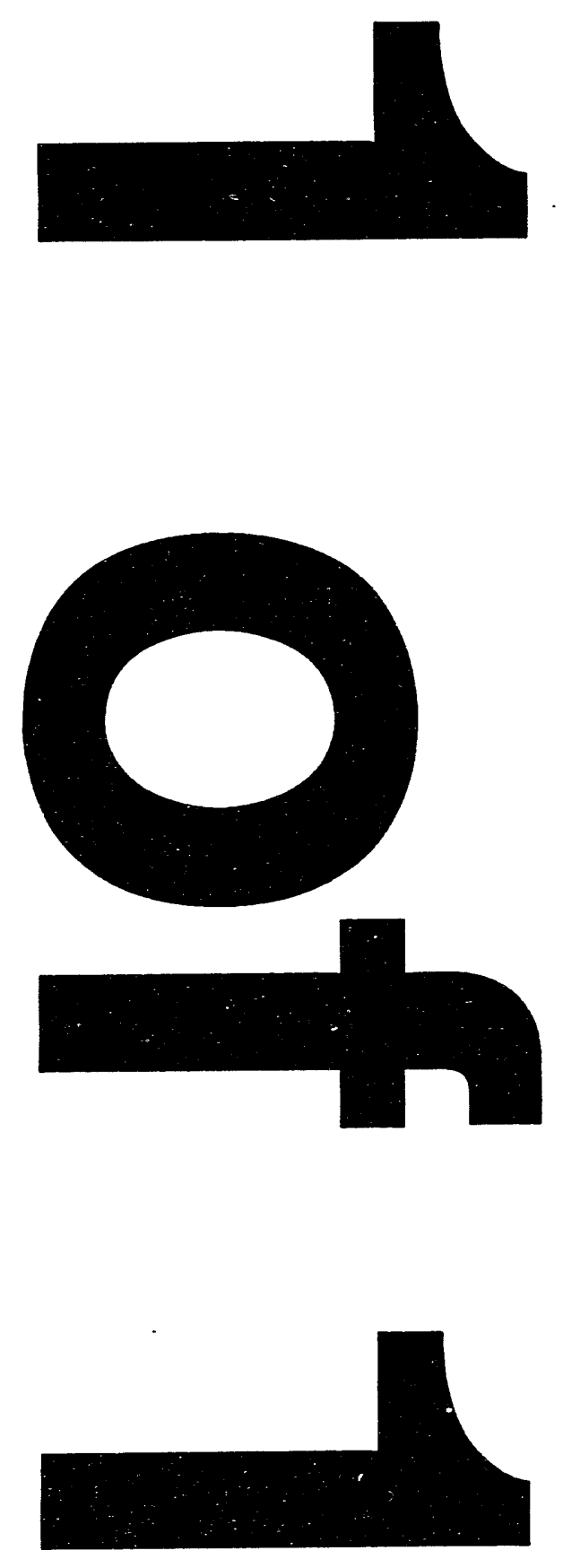
PNL-9023

UC-350

\title{
Industrial Operations and Maintenance \\ Demand-Side Management \\ Resource Development: \\ Literature and Data Review
}

\author{
S. A. Parker \\ K. L. Gaustad \\ R. F. Szydlowski \\ D. W. Winiarski
}

January 1994

Prepared for the Bonneville Power Administration under a Related Services Agreement with the U.S. Department of Energy Contract DE-AC06-76RLO 1830

Pacific Northwest Laboratory

Richland, Washington 99352

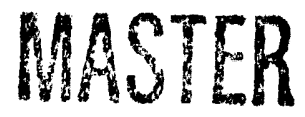




\section{Executive Summary}

The Bonneville Power Administration (Bonneville) commissioned the Pacific Northwest Laboratory $(\mathrm{PNL})^{(\mathrm{a})}$ to determine the industrial demand-side management (DSM) resource potential that may be achieved through operations and maintenance (O\&M) practices in Pacific Northwest industries. This project has its background in the Resource Supply Expansion Program (RSEP).

The overall goal of this project is to determine, confirm, and develop the conservation resources that can be achieved from O\&M practices in Pacific Northwest industries. This project is developmental in nature because its scope involves a sizable task whose path and direction is difficult to define in advance. To accomplish the goal, the project is divided into seven major tasks: 1) reviewing literature and data, 2) preparing project design and work plan, 3) establishing preaudit methodology, 4) performing plant audits, 5) implementing audit recommendations, 6) monitoring and documenting results, and 7) accomplishing technology transfer.

To assist in developing the specific goals and objectives of this ongoing project and its tasks, Bonneville and PNL assembled a Technical Advisory Committee (TAC) to act in both technical support and managerial steering roles. This report outlines the findings of the literature and data review (Task 1), which includes industrial electric end-use consumption estimates and industrial electric O\&M energy conservation opportunities with potential energy savings.

The results of this study identify a significant electric resource potential available through O\&M activities, both nationally and for the Pacific Nortiwest. The overall potential in the Pacific Northwest, identified in this study, ranges from a low of 4,903 million $\mathrm{kWh} / \mathrm{yr}$ (559.7 aMW) from the Energy Analysis and Diagnostic Center (EADC) database analysis to a high of 7,414 million $\mathrm{kWh} / \mathrm{yr}(846.3 \mathrm{aMW})$ from the general literature review.

The equipment category with the largest energy-savings potential is air compressors and compressed-air systems, followed closely by motors and motor drive systems. Table S.1 identifies the Pacific Northwest energy-savings potential by major end-use category derived from the EADC database. The specific O\&M measure with the largest potential is repairing leaks in compressed-air lines. The ten industrial O\&M energy measures with the largest energy-savings potential derived from the EADC database are identified in Table S.2. The industry with the largest energy-savings potential in the Pacific Northwest through O\&M activities is Paper and Allied Products (standard industrial classification [SIC] code 26).

Based on the results of this study, the recommendation is to proceed with the additional project tasks to verify the O\&M electric energy resource potential of air compressors and compressed-air systems, or the second alternative, motors and motor drive systems. Both of these categories offer significant energy-savings potential that can be readily achieved and maintained.

(a) Pacific Northwest Laboratory is operated by Battelle Memorial Institute for the U.S. Department of Energy under Contract DE-ACO6-76RLO 1830. 
Table S.1. Summary of Pacific Northwest Industrial O\&M Energy-Savings Potential by Major End-Use Category, 1990

\section{Major DIECO End-Use Category}

Air compressors and compressed-air systems

Motors and motor drive systems

Lighting

Heating, ventilating, and air conditioning systems

Equipment scheduling and control systems

Insulation

Ventilation systems

Refrigeration systems

Other miscellaneous opportunities

Total

\author{
PNW Potential \\ (million $\mathrm{kWh} / \mathrm{yr}$ )
}

$1,482.37$

$1,129.63$

813.09

449.44

431.35

183.23

124.64

78.47

211.20

$4,903.42$
PNW Potential
$(\mathrm{aMW})^{(\boldsymbol{*})}$

169.2

129.0

92.8

51.3

49.2

20.9

14.2

9.0

24.1

559.8

(a) $1 \mathrm{aMW}=8.76$ million $\mathrm{kWh} / \mathrm{yr}$

Table S.2. Top Ten Industrial O\&M Energy-Saving Measures in the Pacific Northwest, 1990

\begin{tabular}{|c|c|c|c|c|}
\hline DIECO & DIECO Deacription & $\begin{array}{l}\text { End-Use } \\
\text { Equipment }\end{array}$ & $\begin{array}{l}\text { PNW Potential } \\
\text { (million } \mathrm{kWh} / \mathrm{yr} \text { ) }\end{array}$ & $\begin{array}{l}\text { PNW Potential } \\
\text { (aMW) }\end{array}$ \\
\hline 3231 & Eliminate leaks in lines and valves carrying compresed-air or other gaves & Air Compreason & $1,040.46$ & 118.8 \\
\hline 5122 & Improve lubrication practices for motor-driven equipmeat & Motors & 613.34 & 70.0 \\
\hline 5355 & Une energy-efficient belte and other improved mechanioms & Moton & 491.69 & 56.1 \\
\hline 4112 & Reduce operating time of equipment to the minimum required/inetall timen & Controle & 278.81 & 31.8 \\
\hline 6121 & Inutall timen or motion sensors on linle uned lights or initinte echodule & Lighting & 253.62 & 29.0 \\
\hline 6111 & Dieconnect lighting fixtures, delamp, or ure lower output lampe for min. light neoded & Lighting & 248.16 & 28.3 \\
\hline 3221 & Install compressor air intake in cooleat location & Air Comprewon & 190.97 & 21.8 \\
\hline 3211 & Roduce the pressure of compressed air nystem to the minimum required & Air Compreseon & 175.13 & 20.0 \\
\hline 5511 & Inoulate tanke, veasels, lines, and procen equipment & Inoulation & 166.35 & 19.0 \\
\hline 6244 & Install or wee timen or thermostats for apace conditioning & HVAC & 146.79 & 16.8 \\
\hline
\end{tabular}




\section{Acknowledgements}

The authors would like to thank Karl Vischer, Bonneville Power Administration, and Jeff James, U.S. Department of Energy (DOE)-Seattle Support Office, for providing information critical to the completion of this report. Appreciation is extended to Bette Stewart, Portland General Electric (PGE)-Energy Resource Group, and Maghan Jonee-Guinn, PGE, whose efforts supported this study. Thanks also go to the Technical Advisory Committee (TAC) (Karl Vischer, Bonneville Power Administration; Jeff James, DOE-Seattle Support Office; Gary Mitchell, PGE-Energy Resource Group; Mark Kendall, Oregon Department of Energy; and Greg Wheeler, Oregon State University) for their efforts and guidance in support of this project. 


\section{Contents}

Executive Summary $\ldots \ldots \ldots \ldots \ldots \ldots \ldots \ldots \ldots \ldots \ldots \ldots \ldots \ldots \ldots$ iii

Acknowledgements $\ldots \ldots \ldots \ldots \ldots \ldots \ldots \ldots \ldots \ldots \ldots \ldots \ldots \ldots \ldots \ldots$

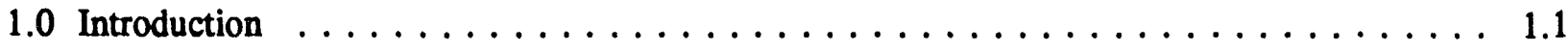

2.0 Industrial Electric End-Use Consumption Estimates $\ldots \ldots \ldots \ldots \ldots \ldots \ldots \ldots$

2.1 Electrotechnology Reference Guide $\ldots \ldots \ldots \ldots \ldots \ldots \ldots \ldots \ldots \ldots .1$

2.2 Electric Motors: Markets, Trends, and Applications $\ldots \ldots \ldots \ldots \ldots \ldots \ldots .1$

2.3 Pacific Northwest Power Planning Council Industrial Energy Demand Model $\ldots \ldots 2.1$

2.4 Other Sources $\ldots \ldots \ldots \ldots \ldots \ldots \ldots \ldots \ldots \ldots \ldots \ldots \ldots \ldots \ldots \ldots \ldots \ldots \ldots \ldots \ldots, 2$

2.4.1 Technical Assessment Guide $\ldots \ldots \ldots \ldots \ldots \ldots \ldots \ldots \ldots 2.2$

2.4.2 Industrial End-Use Planning Methodology $\ldots \ldots \ldots \ldots \ldots \ldots \ldots 2.2$

2.4.3 Energy-Use Patterns and Indicators $\ldots \ldots \ldots \ldots \ldots \ldots \ldots \ldots .2$

2.4.4 Industrial Market Information System $\ldots \ldots \ldots \ldots \ldots \ldots \ldots .3$

2.4.5 Noyes Data Corporation Series in Energy Conservation . . . . . . . 2.3

2.4.6 Marketing Electricity to Industrial Consumers: A Study of Pacific
Northwest Industries $\ldots \ldots \ldots \ldots \ldots \ldots \ldots \ldots \ldots \ldots \ldots \ldots \ldots \ldots$

2.4.7 Bonneville Industrial Sector Conservation Supply Curve Database $\ldots \ldots 2.3$

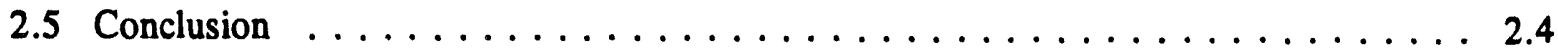

3.0 Industrial Electric O\&M Energy Conservation Opportunities and Potential Energy Savings . 3.1

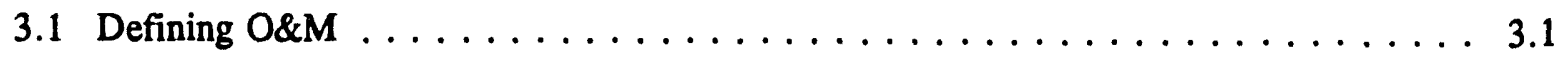

3.2 Findings of Industrial Electric O\&M Potential Energy Savings $\ldots \ldots \ldots \ldots .2$

3.3 Energy Analysis and Diagnostic Center Database $\ldots \ldots \ldots \ldots \ldots \ldots \ldots . \ldots \ldots$

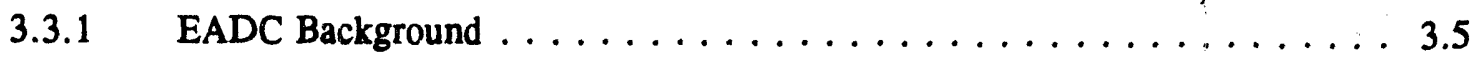

3.3.2 Database Description $\ldots \ldots \ldots \ldots \ldots \ldots \ldots \ldots \ldots \ldots . .5$

vii 
3.3.3 Advantages and Limitations of the Database $\ldots \ldots \ldots \ldots . \ldots \ldots$

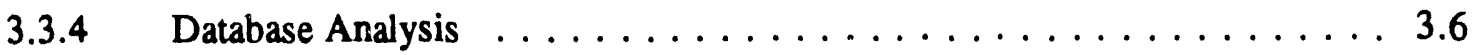

3.3.5 Application at the National Level $\ldots \ldots \ldots \ldots \ldots \ldots . \ldots \ldots$

3.3.6 Application to the Pacific Northwest $\ldots \ldots \ldots \ldots \ldots$

4.0 O\&M Impact Analysis in the Pulp and Paper Industry $\ldots \ldots \ldots \ldots \ldots \ldots$

4.1 Energy Consumption Characteristics $\ldots \ldots \ldots \ldots \ldots \ldots \ldots \ldots \ldots \ldots \ldots$

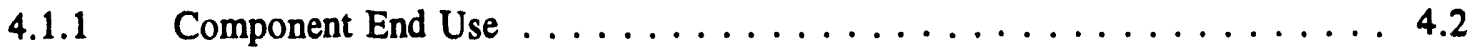

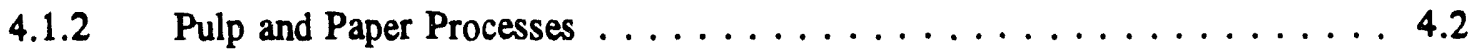

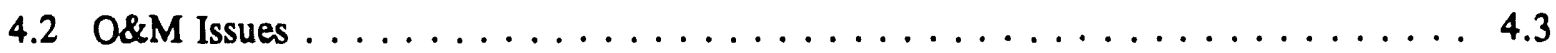

4.2.1 General O\&M Techniques $\ldots \ldots \ldots \ldots \ldots \ldots \ldots \ldots$

4.2.2 O\&M Practices in the Pulp and Paper Industry $\ldots \ldots \ldots \ldots . \ldots$

4.3 O\&M Impacts $\ldots \ldots \ldots \ldots \ldots \ldots \ldots \ldots \ldots \ldots \ldots \ldots \ldots$

4.3.1 The Paper Machine . . . . . . . . . . . . . . . 4.5

4.3.2 Rotating Equipment $\ldots \ldots \ldots \ldots \ldots \ldots \ldots$

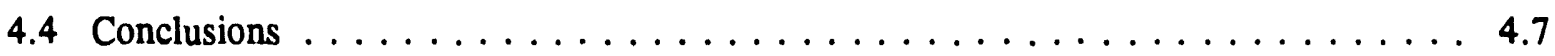

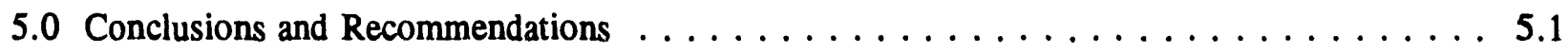

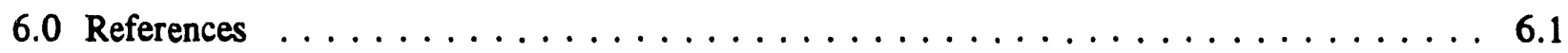




\section{Figures}

2.1 Estimated National Manufacturing Electricity Consumption by End-Use Category

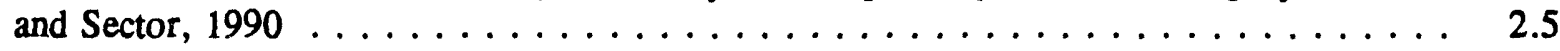

3.1 Number of Surveys in EADC Database $\ldots \ldots \ldots \ldots \ldots \ldots$

3.2 Number of Recommendations in EADC Database $\ldots \ldots \ldots \ldots \ldots \ldots$

3.3 Number of Recommendations by DIECO in EADC Database $\ldots \ldots \ldots \ldots \ldots$

3.4 Number of Recommendations by SIC in EADC Database $\ldots \ldots \ldots \ldots \ldots \ldots$

3.5 Frequency of Recommendations in EADC Database $\ldots \ldots \ldots \ldots \ldots \ldots$

3.6 Frequency of Recommendations by DIECO in EADC Database . . . . . . . . . 3.15

3.7 Average Energy Savings Identified in EADC Database $\ldots \ldots \ldots \ldots \ldots \ldots$

3.8 Average Energy Savings by DIECO Identified in EADC Database $\ldots \ldots \ldots \ldots$

3.9 Summary of Energy-Savings Potential $\ldots \ldots \ldots \ldots \ldots \ldots \ldots$

3.10 Summary of Energy-Savings Potential by DIECO $\ldots \ldots \ldots \ldots \ldots$

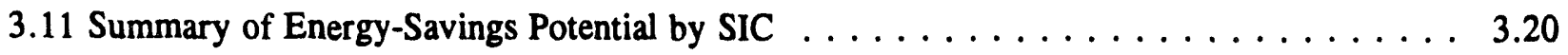

3.12 National Industrial O\&M Energy-Savings Potential $\ldots \ldots \ldots \ldots \ldots \ldots \ldots$

3.13 National Industrial O\&M Energy-Savings Potential by DIECO $\ldots \ldots \ldots \ldots . \ldots \ldots$

3.14 National Industrial O\&M Energy-Savings Potential by SIC $\ldots \ldots \ldots \ldots \ldots$

3.15 Supply Curve of National Industrial O\&M Energy-Saving Measures $\ldots \ldots \ldots$. . . . . . 3.24

3.16 Pacific Northwest Industrial O\&M Energy-Savings Potential $\ldots \ldots \ldots \ldots \ldots$

3.17 Pacific Northwest Industrial O\&M Energy-Savings Potential by DIECO $\ldots \ldots \ldots$

3.18 Pacific Northwest Industrial O\&M Energy-Savings Potential by SIC $\ldots \ldots \ldots \ldots$. . . . 3.27

3.19 Supply Curve of Pacific Northwest Industrial O\&M Energy-Saving Measures $\ldots \ldots$. . . 3.28

4.1 Pulp and Paper O\&M Energy Conservation Potential $\ldots \ldots \ldots \ldots \ldots$ 


\section{Tables}

S.1 Summary of Pacific Northwest Industrial O\&M Energy-Savings Potential by Major End-Use Category, $1990 \ldots \ldots \ldots \ldots \ldots \ldots \ldots \ldots \ldots \ldots \ldots \ldots$. . . . . . . . . . . . . . . . . .

S.2 Top Ten Industrial O\&M Energy-Saving Measures in the Pacific Northwest, 1990 . . . . . iv

2.1 National Manufacturing End-Use Applications of Electricity by Category

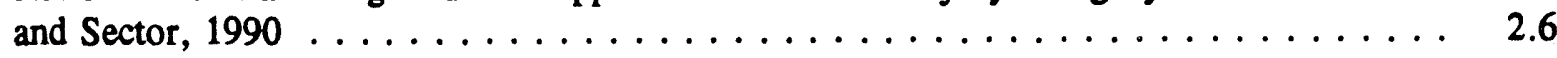

2.2 National Manufacturing Sector Motor Drive Electricity Use, $1985 \ldots \ldots \ldots$

2.3 Estimated National Manufacturing Electricity Consumption by End-Use

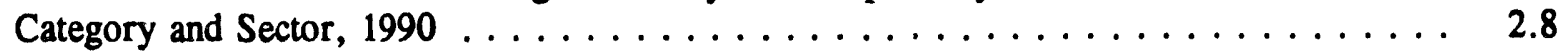

2.4 Pacific Northwest Power Planning Council Industrial Energy Demand Regional Total for All Industries by Two-Digit SIC, $1990 \ldots \ldots \ldots \ldots \ldots$

2.5 Estimated Manufacturing Electricity Consumption by End-Use Category and Sector for the Pacific Northwest, $1990 \ldots \ldots \ldots \ldots \ldots \ldots$

2.6 Process Description Code for IMIS Database $\ldots \ldots \ldots \ldots \ldots \ldots \ldots \ldots$

2.7 Pacific Northwest Electric-Load Sharedowns by Industry, Bonneville ISCSC

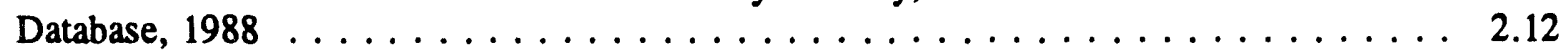

3.1 Industrial Electric O\&M Energy-Saving Measures and Potential $\ldots \ldots \ldots \ldots . \ldots$

3.2 Industrial Electric O\&M Measures by DIECO $\ldots \ldots \ldots \ldots \ldots \ldots$

3.3 Number of $S u: v e y s$ in EADC Database $\ldots \ldots \ldots \ldots \ldots \ldots \ldots$

3.4 Number of Recommendations in EADC Database $\ldots \ldots \ldots \ldots \ldots \ldots . \ldots \ldots$

3.5 Frequency of Recommendations in EADC Database $\ldots \ldots \ldots \ldots \ldots$

3.6 Average Energy Savings Identified in EADC Database $\ldots \ldots \ldots \ldots \ldots . \ldots \ldots$

3.7 Summary of Energy-Savings Potential $\ldots \ldots \ldots \ldots \ldots \ldots \ldots$

3.8 Average DIECO Implementation Cost $\ldots \ldots \ldots \ldots \ldots \ldots \ldots \ldots \ldots \ldots$

3.9 National Industrial O\&M Energy-Savings Potential $\ldots \ldots \ldots \ldots \ldots \ldots \ldots$

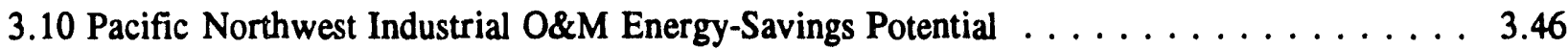


3.11 Pacific Northwest Industrial O\&M Energy-Savings Potential by Equipment End-Use Category $\ldots \ldots \ldots \ldots \ldots \ldots \ldots \ldots \ldots \ldots \ldots \ldots \ldots \ldots \ldots$

4.1 Process and Component Energy Consumption $\ldots \ldots \ldots \ldots \ldots$

4.2 Pulp and Paper Energy Conservation Opportunities $\ldots \ldots \ldots \ldots \ldots \ldots \ldots \ldots$

5.1 Summary of Pacific Northwest Industrial O\&M Energy-Savings Potential, $1990 \quad \ldots \ldots$

5.2 Top Ten Industrial O\&M Energy-Saving Measures in the Pacific Northwest, $1990 \ldots \ldots .2$

5.3 Comparison of O\&M Findings fur the Pacific Northwest $\ldots \ldots \ldots \ldots \ldots$ 


\subsection{Introduction}

Industry in the Pacific Northwest consumes a significant percentage of the total regional electric load; however, industrial demand-side management (DSM) resource development activities in this sector are underdeveloped. One such opportunity for electricity resource development is through operations and maintenance (O\&M) activities.

Despite the importance of industry in the Pacific Northwest, little information has been available on the DSM resource potential, particularly through O\&M activities. To obtain this information, the Bonneville Power Administration (Bonneville) commissioned Pacific Northwest Laboratory (PNL) to study the DSM resource potential that may be achieved through O\&M practices in Pacific Northwest industries. The information from this report will be used to identify one or more specific O\&M activities or industries having significant opportunity for reducing electricity consumption for further evaluation in future tasks to this project.

The overall goal of this project is to determine, confirm, and develop the conservation resources that can be achieved from O\&M practices in Pacific Northwest industries. This project is developmental in nature because its scope involves a sizable task whose path and direction is difficult to define in advance. To accomplish the project goal, the project is divided into seven major tasks: 1) reviewing literature and data, 2) preparing project design and work plan, 3) establishing preaudit methodology, 4) performing plant audits, 5) implementing audit recommendations, 6) monitoring and documenting results, and 7) accomplishing technology transfer. To assist in developing the specific goals and objectives of this ongoing project and its tasks, Bonneville and PNL assembled a Technical Advisory Committee (TAC) to act in both technical support and managerial steering roles.

The primary focus of this report is to summarize the major findings of the literature and data review (Task 1). Detailed analysis and use of all data gathered in the review are beyond the scope of this study. However, the reported findings in this analysis provide an extensive framework for identifying and estimating the electric resource potential available in the industrial manufacturing sector.

This report contains five sections. In Section 2.0, the major sources of industrial electricity enduse consumption estimates are identified and discussed. Section 3.0 presents the estimates of industrial electric O\&M energy-savings potential from a review of published literature and the Energy Analysis and Diagnostic Center (EADC) database obtained from the U.S. Department of Energy (DOE). An impact analysis of O\&M in the pulp and paper industry is presented in Section 4.0. Section 5.0 contains the conclusions of the analysis and presents recommendations for further study. 


\subsection{Industrial Electric End-Use Consumption Estimates}

This section discusses and presents major sources of industrial energy consumption estimates by standard industrial classification (SIC) code, equipment end-use category, or process end-use category. This information functions as a baseline of industrial electric energy consumption, which is used in Section 3.0 to estimate the electric-energy resource potential through O\&M measures.

\subsection{Electrotechnology Reference Guide}

The end-use categories provided in the Electrotechnology Reference Guide (ERG) is one of the most useful sources of end-use data available (Resource Dynamics Corporation 1992a). Although the data is based on professional estimates rather than metered data, ERG breaks out several relevant enduse categories for electric energy consumption. The ERG provides estimates for 1980 , as well as 1990, making it the most up-to-date source identified. Table 2.1 presents the electric end-use data by industry SIC for the 1990 estimate from the ERG.

\subsection{Electric Motors: Markets, Trends, and Applications}

Electric Motors: Markets, Trends, and Applications (MOTORS) is a continuation of the same Electric Power Research Institute (EPRI) project as ERG (Resource Dynamics Corporation 1992b). Whereas ERG only separates motors into three categories, MOTORS further breaks down the energy consumption estimates as shown in Table 2.2. The MOTORS data estimates are for 1985 . By combining the information from ERG and MOTORS, and prorating the data based on the 1990 estimate; the result is Table 2.3, which is illustrated in Figure 2.1. This estimate discounts any disparity in growth rates between the various end-use categories (i.e., assumes the grown rate of fans is the same as pumps and compressors).

\subsection{Pacific Northwest Power Planning Council Industrial Energy Demand Model}

This model provides estimates and projections of the industrial energy consumption for the

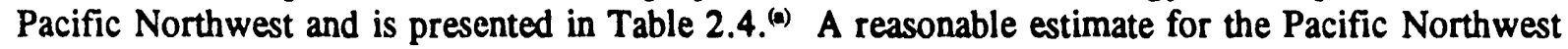
is obtained by assuming the proportional breakdown of electric end-use from Table 2.3 and applying it to the regional estimates in Table 2.4. This estimate is presented in Table 2.5. Although this assumption overlooks regional variances, such as product and fuel mixes, it still provides the best breakdown of end-use categories. All estimates of end-use consumption and potential energy savings used in this study are based on Tables 2.4 and 2.5 .

(a) Pacific Northwest Power Planning Council Industrial Energy Demand Model estimates were provided by Bonneville Power Administration. 


\subsection{Other Sources}

Several other sources were reviev'ed for information concerning energy consumption and enduse breakdowns, some of which are briefly discussed in the following subsections. In general, these sources were not determined to be as applicable to the scope of this study as the previous sources discussed, but do deserve special mention.

\subsubsection{Technical Assessment Guide}

The Technical Assessment Guide (TAG) provides national baseline energy consumption for various manufacturing SIC codes based on 1985 estimates (Resource Dynamics Corporation 1988). The TAG report also describes various industry types, their processes, and technologies. In addition, it evaluates several new technologies. Although the majority of the information contained in the TAG report is not relevant to this study, the baseline information can be useful.

\subsubsection{Industrial End-Use Planning Methodology}

The Industrial End-Use Planning Methodology (INDEPTH) report identifies the percent breakdown of electricity consumption for 20 two-digit industry SIC codes and for 7 major end-use equipment types based on 1986 estimates (Battelle-Columbus Division 1986a). Like ERG and MOTORS, this data is also based on professional estimates rather than metered data. Applying the INDEPTH percentages to a national industrial electric consumption estimate can provide an estimate of electric end-use consumption.

There are certain faults with this information. In particular, the end-use categories are not very specific. The motors category, for example, covers a wide range of applications, including pumps, fans, air compressors, grinders, lathes, conveyors, and a variety of other drive systems. This differentiation in how a motor is applied is important in attributing O\&M practices and therefore its energy reduction potential.

\subsubsection{Energy-Use Patterns and Indicators}

Energy-Use Patterns and Indicators, Volume 1: Summary provides national and regional energy consumption and trend estimates for major fuels (electricity, natural gas, petroleum, and coal) and markets (residential, commercial, and industrial) from 1960 to 1985 (Synergic Resources Corporation 1987). Although the end-use data provided is from INDEPTH, this report also includes electric consumption data for the agriculture, mining, and construction industries in addition to the manufacturing industry. While manufacturing accounted for $84.91 \%$ of the industrial electric energy consumption in 1980, agriculture, mining, and construction accounted for only $1.98 \%, 5.07 \%$, and $8.05 \%$, respectively. Beyond this source, very little other information was discovered concerning the agriculture, mining, and construction industries. Energy-Use Patterns and Indicators did provide agricultural electricity consumption by process end-use for livestock operations and crop operations from a 1978 U.S. Department of Agriculture (USDA) source. 


\subsubsection{Industrial Market Information System}

The Industrial Market Information System (IMIS) database includes baseline estimates of national electric-energy consumption by four-digit SIC and 55 process end-use types (Battelle-Columbus Division 1986b). The process categories are identified in Table 2.6. The IMIS data are copyrighted and therefore not reproduced in this document; however, the data can be extracted from the IMIS software available through EPRI. While the process types are useful in some aspects, they do not correlate with the O\&M measures identified later in Section 3.0. Industrial processes, while descriptive of the activity, usually consist of several equipment components, especially shared auxiliary equipment (such as air compressors). O\&M activities, on the other hand, are usually associated with the equipment or its major components.

\subsubsection{Noyes Data Corporation Series in Energy Conservation}

Noyes Data Corporation published a series of handbooks on energy conservation, environmental control, and industrial processes for several industries from mid-1970 through mid-1980, only a few of which could be reviewed in time for this study. The Noyes handbooks are excellent sources for process descriptions, several of which include percentage breakdowns of energy end-use for both electricity and fossil fuels. The handbooks are also a good source for identifying applications of new technologies and research opportunities throughout industry.

\subsubsection{Marketing Electricity to Industrial Consumers: A Study of Pacific Northwest Industries}

The Marketing Electricity to Industrial Customers report provides percentage breakdowns of enduse energy consumption for five industries in the Pacific Northwest (SIC 20 - Food and Kindred Products, 24 - Lumber and Wood Products, 26 - Paper and Allied Products, 28 - Chemicals and Allied Products, and 33 - Primary Metals Industries) based on 1977 estimates (Northwest Economic Associates 1986). In addition to end-use estimates by two-digit SIC code, the report also provides end-use percentage estimates for a few four-digit SIC codes within each two-digit category. The estimates in this report were derived from previous research by Synergic Resources Corporation in 1981. Although the estimates are from 1977, it is still a good source for identifying major energy consumers within the industries covered. The information discovered through this source, however, is not considered further because it only covers 5 of the 20 two-digit SIC industries.

\subsubsection{Bonneville Industrial Sector Conservation Supply Curve Database}

Although the Bonneville Industrial Sector Conservation Supply Curve (ISCSC) database was not reviewed directly, the data was identified in another source (Baechler et al. 1992). The data, shown in Table 2.7, provides electric-loar breakdowns for 8 two-digit industry SIC codes by 7 end-use categories. Although this is a gor 1 source of regional electric end-use for the Pacific Northwest, the 7 end-use categories were concluded not to be as beneficial as the previously described sources, ERG and MOTORS. 


\subsection{Conclusion}

Because the sources presented in this section provide different end-use categories, it is difficult to merge the various sources together. For example, INDEPTH separates "chillers" from "motors" and "space heating" from "process heating;" while in Table 2.3, "compressors" includes chillers, refrigeration, air compressors, and other compressor equipment end-uses and "space heating" is combined with "lighting and other," with the exception of heat pumps, which is included in "process heating." Unfortunately, the end-use categories are not mutually exclusive and therefore cannot simply be merged into one large end-use breakdown. For this reason, the sources are presented individually for use with Section 3.0 findings as appropriate.

The ERG, MOTORS, and Pacific Northwest Power Planning Council Industrial Energy Demand Model derived resources, whose data are shown in Tables 2.3 and 2.5, provide, in the author's opinion, the most useful information within the manufacturing sector. It is unfortunate, however, that refrigeration compressors and air compressors are combined in the same end-use category; this will become relevant in Section 3.2.

The information derived from this section is used to calculate total energy consumption for a particular end-use category. Section 3.0 identifies the energy-savings potential of various O\&M measures, which combined with the appropriate end-use energy consumption identified in this section, provides an estimate of the electric consumption savings potential. 


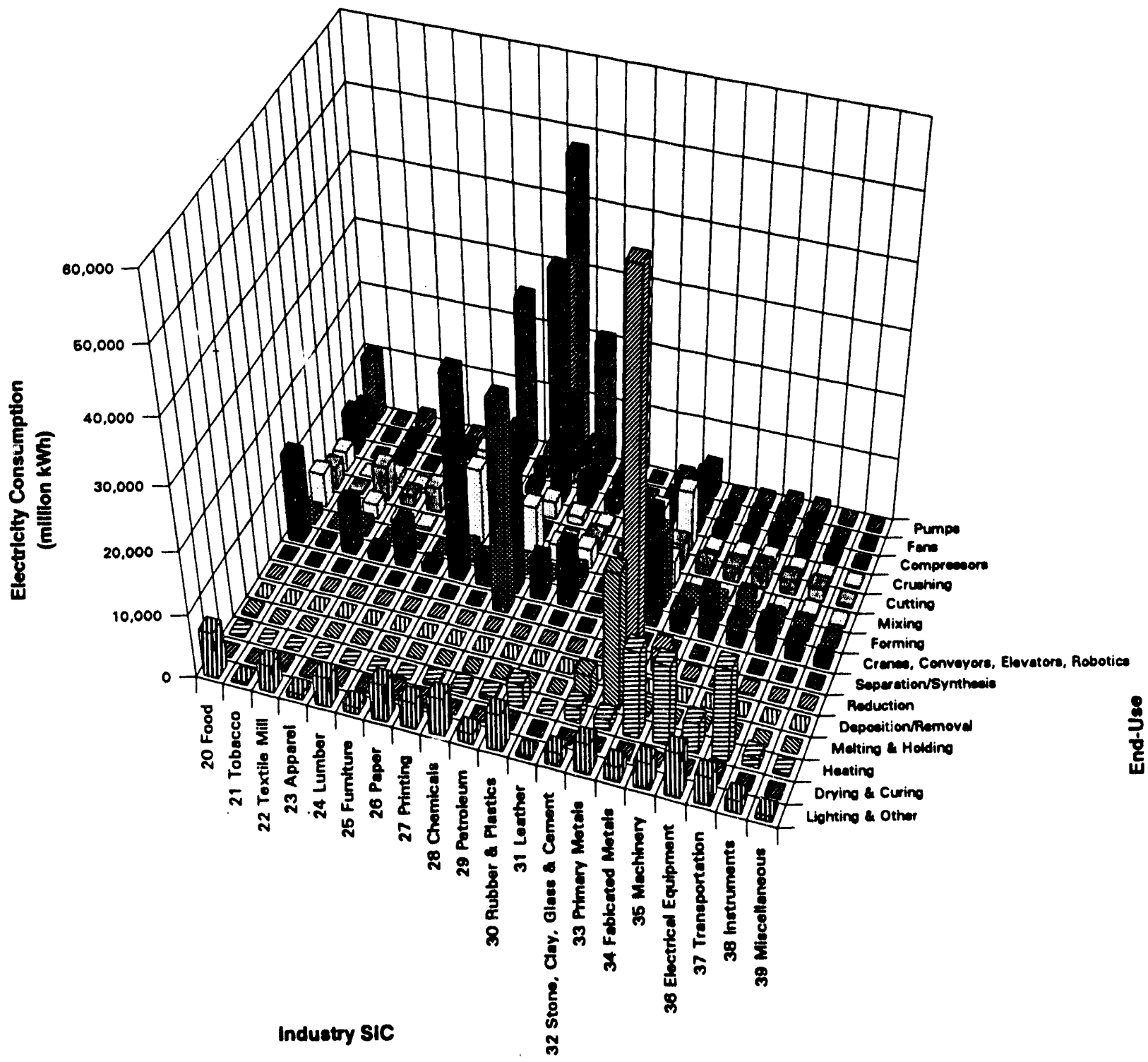

Figure 2.1. Estimated National Manufacturing Electricity Consumption by End-Use Category and Sector, 1990 (million $\mathrm{kWh}$ ) 
Table 2.1. National Manufacturing End-Use Applications of Electricity by Category and Sector, 1990 (million kWh)

\begin{tabular}{|c|c|c|c|c|c|c|c|c|c|c|c|}
\hline \multirow[b]{2}{*}{ sic } & \multicolumn{3}{|c|}{ Motor Drives } & \multicolumn{3}{|c|}{ Eloctrolytics } & \multicolumn{3}{|c|}{ Procoess Hoating } & \multirow{2}{*}{$\begin{array}{l}\text { Uighting } \\
\text { and } \\
\text { Other }\end{array}$} & \multirow[b]{2}{*}{ Tolal } \\
\hline & $\begin{array}{l}\text { Pumps, Fans, } \\
\text { Compressoors }\end{array}$ & $\begin{array}{c}\text { Material } \\
\text { Procesalng }\end{array}$ & $\begin{array}{l}\text { Matorial } \\
\text { Mandling }\end{array}$ & $\begin{array}{l}\text { Separation/ } \\
\text { Symthosis }\end{array}$ & Roduction & $\begin{array}{l}\text { Depostion/ } \\
\text { fomoval }\end{array}$ & $\begin{array}{l}\text { Melting and } \\
\text { Holding }\end{array}$ & Heating & $\begin{array}{l}\text { Drying and } \\
\text { Curing }\end{array}$ & & \\
\hline 20 & 21,700 & 13,600 & 14,000 & 0 & 0 & 0 & 500 & 200 & 0 & 7,300 & 57,300 \\
\hline 21 & 400 & 700 & 600 & 0 & 0 & 0 & 0 & 0 & 0 & 400 & 2,100 \\
\hline 22 & 4,700 & 10,500 & 8,200 & 0 & 0 & 0 & 0 & 0 & 700 & 4,300 & 28,400 \\
\hline 23 & 800 & 2,300 & 1,300 & 0 & 0 & 0 & 0 & 0 & 300 & 800 & 5,800 \\
\hline 24 & 3,400 & 5,500 & 7,000 & 0 & 0 & 0 & 0 & 0 & 300 & 4,700 & 20,800 \\
\hline 25 & 800 & 2,700 & 1,100 & 0 & 0 & 0 & 0 & 0 & 300 & 1.100 & 6,000 \\
\hline 28 & 37,800 & 32,700 & 32,700 & 0 & 0 & 0 & 0 & 0 & 1,500 & 8,000 & 110,800 \\
\hline 27 & 3,400 & 4,800 & 4,400 & 0 & 0 & 0 & 0 & 500 & 800 & 4,300 & 18,300 \\
\hline 28 & 87,800 & 13,100 & 18,800 & 33,300 & 0 & 0 & 0 & 800 & 0 & 0,100 & $17 m, 800$ \\
\hline 29 & 31,800 & 4,300 & 6,400 & 0 & 0 & 0 & 0 & 700 & 0 & 1,800 & 44,800 \\
\hline 30 & 8,000 & 8,100 & 9,700 & 0 & 0 & 0 & 0 & 3,800 & 000 & 5,800 & 36,100 \\
\hline 31 & 100 & 300 & 100 & 0 & o & 0 & 0 & 0 & 0 & 400 & 800 \\
\hline 32 & 4,800 & 10,100 & 8,400 & 0 & 0 & 0 & 4,300 & 2,800 & 0 & 2,100 & 32,300 \\
\hline 33 & 12,200 & 30,300 & 18,300 & 0 & 50,200 & 4,000 & 21,500 & 1,800 & 0 & 4,800 & 152,000 \\
\hline 34 & 2,000 & 5,600 & 3,700 & 0 & 3,800 & 0 & 0 & 13,800 & 200 & 2,500 & 32,300 \\
\hline 35 & 3,300 & 7,300 & 7,600 & 0 & 200 & 0 & 0 & 12,800 & 0 & 4,300 & 35,500 \\
\hline 30 & 6,400 & 10,400 & 4,000 & 0 & 0 & 0 & 0 & 4,700 & 100 & 7,200 & 32,800 \\
\hline 37 & 5,000 & 5,800 & 4,000 & 0 & 200 & 0 & 100 & 14,700 & 1,000 & 4,600 & 30,700 \\
\hline 38 & 1,800 & 8,100 & 3,100 & 0 & 0 & 0 & 0 & 1,000 & 0 & 2,100 & 14,700 \\
\hline 30 & $\infty \infty$ & 1,800 & 1,300 & 0 & 0 & 0 & 0 & 400 & 0 & 800 & 5,100 \\
\hline & 248,300 & 178,300 & 156,100 & 33,300 & 00,500 & 4,000 & 20,400 & 58,200 & 5,800 & 71,000 & 243,500 \\
\hline
\end{tabular}

Source: Copyright ${ }^{\circ}$ 1992. Electric Power Research Institute. EPRI TR-101021, Rev. 2, Electrotechnology Reference Guide. Reprinted with Permission. 
Table 2.2. National Manufacturing Sector Motor Drive Electricity Use, 1985 (million kWh)

\begin{tabular}{|c|c|c|c|c|c|c|c|c|c|}
\hline sic & Pumps & Fans & Compressors & Crushing & Cutting & Mixing & Forming & $\begin{array}{l}\text { Malerial } \\
\text { Handiling }\end{array}$ & Total \\
\hline 20 & 8,100 & 3,800 & 5,300 & 2,600 & 2,700 & 4,300 & 1,300 & $14, \infty 00$ & 12,000 \\
\hline 21 & 100 & 100 & 0 & 0 & 300 & 100 & 100 & 600 & 1,300 \\
\hline 22 & 1,700 & 1,200 & 1,300 & 800 & 5,100 & 2,100 & 1,000 & 8,200 & 22,000 \\
\hline 23 & 300 & 300 & 200 & 100 & 1,700 & 400 & 100 & 1,300 & 4,400 \\
\hline 24 & 800 & 2,000 & 800 & 800 & 4,100 & 500 & 400 & 7,000 & 15,000 \\
\hline 25 & 100 & 300 & 200 & 300 & 1,400 & 100 & 200 & 1,100 & 3,700 \\
\hline 28 & 18,500 & 5,000 & 4,500 & 4,800 & $8, \infty 00$ & 8,000 & 1,600 & 32,700 & 84,800 \\
\hline 27 & 700 & 800 & 700 & 200 & 1,600 & 1,200 & 300 & 4,400 & 0,000 \\
\hline 28 & 33,000 & 0,400 & 24,000 & 1,000 & 400 & 5,400 & 1,200 & 10,600 & 05,800 \\
\hline 29 & 18,600 & 6,300 & 3,700 & 1,200 & 100 & 2,300 & 200 & 6,100 & 38,800 \\
\hline 30 & 3,700 & 1,800 & 1,400 & $\infty 00$ & $1, \infty 00$ & 2,700 & 2,100 & 0,700 & 23,600 \\
\hline 31 & 100 & 100 & 0 & 0 & 200 & 0 & 0 & 100 & 500 \\
\hline 32 & 2,100 & 1,700 & 1,600 & 8,800 & 1,800 & 1,600 & 1,800 & 8,400 & 25,600 \\
\hline 33 & 3,300 & 4,400 & 1,500 & 7,300 & 3,100 & 3,400 & 9,200 & 18,300 & 50,500 \\
\hline 34 & 500 & 1,000 & 1,000 & 100 & 1,500 & 500 & 2,500 & 3,700 & 11,600 \\
\hline 35 & 800 & 1,200 & 1,000 & 1,100 & 2,100 & 500 & 2,700 & 7,600 & 17,000 \\
\hline 38 & 2,000 & 3,200 & 2,000 & 2,000 & 3,000 & 1,100 & 8,100 & 4,000 & 25,200 \\
\hline 37 & 2,000 & 2,800 & 2,800 & 1,100 & 3,000 & 700 & 3,200 & 4,000 & 20,200 \\
\hline 38 & 200 & 300 & 400 & 400 & 1,000 & 800 & 1,100 & 3,100 & 7,000 \\
\hline \multirow[t]{2}{*}{39} & 100 & 100 & 100 & 200 & 300 & 200 & 500 & 1,300 & 2,800 \\
\hline & 86,700 & 45,800 & 34,100 & 32,500 & 44,800 & 38,500 & 38,200 & 158,100 & 502,700 \\
\hline
\end{tabular}

Source: Copyright ${ }^{\oplus}$ 1992. Electric Power Research Institite. EPRI TR-100423, Electric Motors: Markets, Trends, and Applications. Reprinted with Permission. 
Table 2.3. Estimated National Manufacturing Electricity Consumption by End-Use Category and Sector, 1990 (million kWh)

\begin{tabular}{|c|c|c|c|c|c|c|c|c|c|}
\hline \multirow[b]{2}{*}{ SIC } & \multirow[b]{2}{*}{ Industry } & \multicolumn{7}{|c|}{ Motor Dives } & \multirow[b]{2}{*}{$\begin{array}{l}\text { Malerial } \\
\text { Handling }\end{array}$} \\
\hline & & Pumpe & Fans & Comprewers & Cruahing & Cutting & Mixing & Forming & \\
\hline 20 & Food and Kindred Products & 10,219 & 4,704 & 6,687 & 3,148 & 3,400 & 5,415 & 1,637 & 14,000 \\
\hline 21 & Tobaceo & 200 & 200 & 0 & 0 & 420 & 140 & 140 & 600 \\
\hline 22 & Textlle Mill Products & 1,802 & 1,343 & 1,455 & 875 & 5,578 & 2,207 & 1,750 & 8,200 \\
\hline 23 & Apparel and Other Toxtlie Products & 300 & 300 & 200 & 100 & 1,700 & 400 & 100 & 1,300 \\
\hline 24 & Lumber and Wood Products & 800 & 2,000 & 600 & 500 & 4,100 & 500 & 400 & 7,000 \\
\hline 25 & Fumiture and Fixtures & 133 & 400 & 287 & 405 & 1,800 & 135 & 270 & 1,100 \\
\hline 26 & Paper and Alled Products & 25,041 & 6,768 & 0,001 & 6,480 & 12,028 & 12,028 & 2,162 & 32,700 \\
\hline 27 & Printing and Publishing & 1,082 & 1,236 & 1,082 & 297 & 2,376 & 1,782 & 445 & 4,400 \\
\hline 28 & Chemicals and Allod Products & 48,004 & 13,874 & 38,2202 & 2,707 & 569 & 7,248 & 1,768 & 18,800 \\
\hline 29 & Potroloum and Con Products & 20,746 & 7,027 & 4,127 & 1,358 & 113 & 2,8003 & 220 & 6,400 \\
\hline 30 & Rubber and Piestice Products & 4,280 & 2,087 & 1,623 & 604 & 1,851 & 3,124 & 2,430 & 0,700 \\
\hline 31 & Loather and Leather Products & 50 & 50 & 0 & 0 & 300 & 0 & 0 & 100 \\
\hline 32 & Stone, Clay, Glase, and Concrete Product & 1,867 & 1,611 & 1,422 & 8,040 & 1,541 & 1,360 & $1,5,1$ & 8,400 \\
\hline 33 & Primary Molal induotrios & 4,376 & 6,836 & 1,000 & 0,017 & 4,084 & 4,470 & 12,120 & 18,300 \\
\hline 34 & Fabricated Metul Producte & 520 & 1,040 & 1,040 & 023 & 1,556 & 518 & 2,583 & 3,700 \\
\hline 35 & Machinery, except Electrical & 880 & 1,320 & 1,100 & 1,255 & 2,305 & 570 & 3,080 & 7,600 \\
\hline 36 & Electric and Etectronic Equipment & 1,580 & 2,528 & 2,291 & 1,588 & 3,006 & 873 & 4,843 & 4,000 \\
\hline 37 & Transportation Equipment & 1,474 & 2,063 & 2,083 & 811 & 2,213 & 518 & 2,360 & 4,600 \\
\hline 38 & Instruments and Polatod Products & 400 & 600 & 800 & 813 & 2,033 & 1,017 & 2,237 & 3,100 \\
\hline 39 & Miscellaneous Manufacturing Induatries & 200 & 200 & 200 & 317 & 475 & 317 & 782 & 1,300 \\
\hline & Total & 124,065 & 54,877 & 60,258 & 37,643 & 51,736 & 40,030 & 40,891 & 156,100 \\
\hline
\end{tabular}

\begin{tabular}{|c|c|c|c|c|c|c|c|c|c|}
\hline \multirow[b]{2}{*}{ SiC } & \multirow[b]{2}{*}{ Industry } & \multicolumn{3}{|c|}{ Electrolytics } & \multicolumn{3}{|c|}{ Procese Hoaling } & \multirow{2}{*}{$\begin{array}{c}\text { Ughting } \\
\text { and } \\
\text { Other }\end{array}$} & \multirow[b]{2}{*}{ Total } \\
\hline & & $\begin{array}{l}\text { Soparation/ } \\
\text { Synthesis }\end{array}$ & Reduction & $\begin{array}{l}\text { Depostition/ } \\
\text { Removal }\end{array}$ & $\begin{array}{l}\text { Molling and } \\
\text { Holding }\end{array}$ & Heating & $\begin{array}{l}\text { Drying and } \\
\text { Curing }\end{array}$ & & \\
\hline 20 & Food and Kindred Products & 0 & 0 & 0 & 500 & 200 & 0 & 7,300 & 57,300 \\
\hline 21 & Tobacco & 0 & 0 & 0 & 0 & 0 & 0 & 400 & 2,100 \\
\hline 22 & Textile Mill Products & 0 & 0 & 0 & 0 & 0 & 700 & 4,300 & 28,400 \\
\hline 23 & Apparel and Other Textile Products & 0 & 0 & 0 & 0 & 0 & 300 & 800 & 5,600 \\
\hline 24 & Lumber and Wood Products & 0 & 0 & 0 & 0 & 0 & 300 & 4,700 & 20,800 \\
\hline 25 & Furniture and Fixtures & 0 & 0 & 0 & 0 & 0 & 300 & 1,100 & 6.000 \\
\hline 26 & Paper and Allied Products & 0 & 0 & 0 & 0 & 0 & 1,500 & $6, \infty 00$ & 110,800 \\
\hline 27 & Printing and Publiahing & 0 & 0 & 0 & 0 & 500 & 800 & 4,300 & 18,300 \\
\hline 28 & Chemicals and Allied Products & 33,300 & 0 & 0 & 0 & 800 & 0 & 6,100 & 170,800 \\
\hline 28 & Petroleum and Coal Products & 0 & 0 & 0 & 0 & 700 & 0 & 1,600 & 44,900 \\
\hline 30 & Flubber and Plastics Products & 0 & 0 & 0 & 0 & 3,800 & 600 & 5,800 & 36,100 \\
\hline 31 & Leather and Leather Products & 0 & 0 & 0 & 0 & 0 & 0 & 400 & 800 \\
\hline 32 & Stone, Clay, Glass, and Concreto Products & 0 & 0 & 0 & 4,300 & 2,600 & 0 & 2,100 & 32,300 \\
\hline 33 & Primary Metal industries & 0 & 59,200 & 4,000 & 21,500 & 1,600 & 0 & 4,800 & 152,000 \\
\hline 34 & Fabricated Metal Products & 0 & 3,800 & 0 & 0 & 13,800 & 200 & 2,500 & 32,300 \\
\hline 35 & Machinery, except Electrical & 0 & 200 & 0 & 0 & 12,800 & 0 & 4,300 & 35,500 \\
\hline 38 & Electic and Eloctronic Equlpment & 0 & 0 & 0 & 0 & 4,700 & 100 & 7,200 & 32,800 \\
\hline 37 & Transportation Equipment & 0 & 200 & 0 & 100 & 14,700 & 1,000 & 4,600 & 36,700 \\
\hline 38 & Instruments and Rolated Products & 0 & 0 & 0 & 0 & 1,600 & 0 & 2,100 & 14,700 \\
\hline \multirow[t]{2}{*}{38} & Misceilaneous Manufacturing Industriee & 0 & 0 & 0 & 0 & 400 & 0 & 800 & 5,100 \\
\hline & Total & 33,300 & 63,500 & 4,000 & 28,400 & 58,200 & 5,800 & 71,600 & 843,500 \\
\hline
\end{tabular}


Table 2.4. Pacific Northwest Power Planning Council Industrial Energy Demand Regional Total for All Industries by Two-Digit SIC, 1990 (aMW)

\begin{tabular}{|c|c|c|}
\hline SIC. & Industry & $\begin{array}{c}1990 \\
\text { (aMW) }\end{array}$ \\
\hline 20 & Food and Kindred Products & 296.68 \\
\hline 21 & Tobacco & $\sim 0.00$ \\
\hline 22 & Textlle Mill Products & 5.73 \\
\hline 23 & Apparel and Other Textile Products & 4.02 \\
\hline 24 & Lumber and Wood Products & 528.37 \\
\hline 25 & Fumiture and Flxtures & 4.83 \\
\hline 26 & Paper and Allied Products & $1,495.15$ \\
\hline 27 & Printing and Publishing & 50.13 \\
\hline 28 & Chemicals and Allied Products & 770.80 \\
\hline 29 & Petroleum and Coal Products & 106.87 \\
\hline 30 & Rubber and Plastics Products & 91.20 \\
\hline 31 & Leather and Leather Products & $\sim 0.00$ \\
\hline 32 & Stone, Clay, Glass, and Concrete Products & 134.37 \\
\hline 33 & Primary Metal Industries & $2,831.17$ \\
\hline 34 & Fabricated Metal Products & 61.81 \\
\hline 35 & Machinery, except Electrical & 133.36 \\
\hline 36 & Electric and Electronic Equipment & 60.60 \\
\hline 37 & Transportation Equipment & 168.68 \\
\hline 38 & Instruments and Related Products & 12.37 \\
\hline \multirow[t]{3}{*}{39} & Miscellaneous Manufacturing Industries & 14.72 \\
\hline & Residual & 35.55 \\
\hline & Total & $6,806.41$ \\
\hline
\end{tabular}


Table 2.5. Estimated Manufacturing Electricity Consumption by End-Use Category and Sector for the Pacific Northwest, 1990 (million $k W h$ )

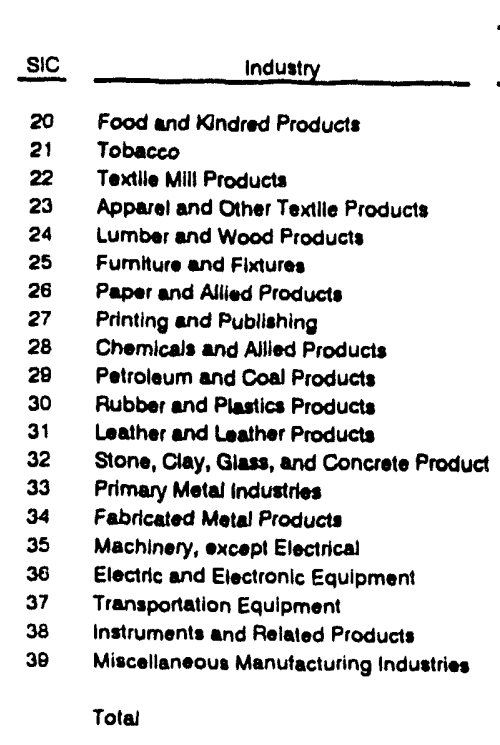

\begin{tabular}{|c|c|c|c|c|c|c|c|}
\hline \multicolumn{8}{|c|}{ Molor Drwes } \\
\hline Pumpe & Fans: & Compreasion & Crushing & Cutting & Mixing & Forming & $\begin{array}{l}\text { Malorial } \\
\text { Handling }\end{array}$ \\
\hline 483.5 & 217.4 & 303.3 & 142.8 & 1542 & 245.6 & 74.2 & 635.0 \\
\hline 0.0 & 0.0 & 0.0 & 0.0 & 0.0 & 0.0 & 0.0 & 0.0 \\
\hline 3.4 & 2.4 & 2.6 & 1.5 & 9.0 & 4.1 & 3.1 & 14.5 \\
\hline 1.8 & 1.0 & 1.3 & 0.0 & 10.7 & 2.5 & 0.6 & 8.2 \\
\hline 177.2 & 442.0 & 132.0 & 110.7 & $\infty 08.0$ & 110.7 & 88.6 & $1,550.2$ \\
\hline 0.0 & 2.8 & 1.0 & 20 & 13.3 & 1.0 & 1.8 & 7.8 \\
\hline $2,060.1$ & 800.0 & 720.0 & 768.7 & $1,421.6$ & $1,421.8$ & 255.6 & $3,885.4$ \\
\hline 28.0 & 20.7 & 28.0 & 7.1 & 57.0 & 42.8 & 10.7 & 105.6 \\
\hline $1,897.8$ & 540.6 & $1,431.0$ & 110.8 & 23.3 & 314.2 & 69.8 & 774.8 \\
\hline 432.8 & 146.5 & 88.0 & 28.3 & 2.4 & 54.3 & 4.7 & 133.4 \\
\hline 24.8 & 46.2 & 35.0 & 15.4 & 41.0 & 69.1 & 53.8 & 214.7 \\
\hline 0.0 & 0.0 & 0.0 & 0.0 & 0.0 & 0.0 & 0.0 & 0.0 \\
\hline 68.0 & 55.1 & 51.8 & 200.8 & 56.1 & 49.8 & 58.1 & 308.1 \\
\hline 714.0 & 852.0 & 324.6 & $1,600.1$ & 860.4 & 730.8 & $1,077.8$ & $2,885.8$ \\
\hline 8.7 & 17.4 & 17.4 & 15.6 & 26.1 & 8.7 & 43.5 & 62.0 \\
\hline 29.0 & 43.4 & 36.2 & 41.3 & 78.8 & 18.8 & 101.3 & 250.1 \\
\hline 25.8 & 40.8 & 37.1 & 25.7 & 50.1 & 14.1 & 78.4 & 64.7 \\
\hline 59.3 & 83.1 & 83.1 & 32.7 & 89.1 & 20.8 & 95.0 & 185.2 \\
\hline 2.8 & 4.4 & 5.8 & 6.0 & 15.0 & 7.5 & 16.5 & 22.0 \\
\hline 5.1 & 5.1 & 5.1 & 8.0 & 12.0 & 8.0 & 20.0 & 32.8 \\
\hline $6,870.8$ & $3,431.8$ & $3,302.8$ & $3,000.0$ & $3,634.8$ & $3,124.4$ & $2,851.4$ & $11,218.4$ \\
\hline
\end{tabular}

\begin{tabular}{ll} 
SIC & \multicolumn{1}{c}{ Industry } \\
20 & Food and Kndred Products \\
21 & Tobacco \\
22 & Textlie Mill Products \\
23 & Apparel and Other Textlle Products \\
24 & Lumber and Wood Products \\
25 & Furniture and Fixtures \\
26 & Paper and Allied Products \\
27 & Printing and Publishing \\
28 & Chemicals and Allied Products \\
29 & Petroleum and Coal Products \\
30 & Rubber and Plastics Products \\
31 & Leather and Leather Products \\
32 & Stone, Clay, Glass, and Concrate Product \\
33 & Primay Motal Industries \\
34 & Fabricated Mettal Products \\
35 & Machinery, oxcept Electrical \\
36 & Electric and Eloctronic Equipment \\
37 & Transportation Equipment \\
38 & Instruments and Relaled Products \\
39 & Miscelianeous Manufacturing industries
\end{tabular}

Eloctrolylics
Synthesis
0.0 Roduction $\begin{gathered}\text { Deposition/ } \\ \text { Removal }\end{gathered}$

Proces
Molling and
Holding

Process Heating

Drying and
Moating Curing

Ughting

22.7 Hoaling Curing

0.0
0.0
0.0
0.0
0.0
0.0
0.0
0.0
$1,316.4$
0.0
0.0
0.0
0.0
0.0
0.0
0.0
0.0
0.0
0.0
0.0

0.0
0.0
0.0
0.0
0.0
0.0
0.0
0.0
0.0
0.0
0.0
0.0
0.0
652.7
0.0
0.0
0.0
0.0
0.0
0.0

$3,508.0$

0.1
0.0
0.0
0.0

0.0

331.1

$2,598.8$

$0.0 \quad 0.0$

$\begin{array}{ll}7.8 & 50.2\end{array}$

$5.7 \quad 35.2$

$1,040.8 \quad 4,628.5$

$\begin{array}{rr}7.8 & 42.3 \\ 708.3 & 13,097.5\end{array}$

$\begin{array}{rr}103.2 & 439.1\end{array}$

$241.2 \quad 6,752.2$

$33.4 \quad 036.2$

$\begin{array}{rr}33.4 & 936.2 \\ 130.6 & 798.8\end{array}$

$0.0 \quad 0.0$

$76.5 \quad 1,177.1$

$789.5 \quad 24,801.0$

$41.8 \quad 541.5$

$141.5 \quad 1,168.2$

$116.5 \quad 530.8$

$185.236,700.0$

$15.5 \quad 14,700.0$

$22.8 \quad 128.8$

Total

$1,316.4 \quad 0,739,4$

052.7

$1,848,6$

328.7

4.000 .8

$59,312.7$ 
Table 2.6. Process Description Code for IMIS Database

\begin{tabular}{|c|c|}
\hline $\begin{array}{l}\text { Proceas } \\
\text { Code }\end{array}$ & Procen Description \\
\hline 1 & CUTTING, SAWING, SLTITING \\
\hline 2 & TURNING \\
\hline 3 & ORINDING \\
\hline 4 & GRAR CUTTINO \\
\hline 5 & ROLLNO \\
\hline 6 & EXTRUSION \\
\hline 7 & PORGNG, UPSETTING \\
\hline 8 & DRAWINO \\
\hline 9 & FINLSH ROLINNO \\
\hline 10 & ROTARY FORMING, SWAGING \\
\hline 11 & STAMPINO \\
\hline 12 & DERP DRAWING \\
\hline 13 & EMBOSSING, CONnNG \\
\hline 14 & FORMING \\
\hline 15 & POWDER METALLURGY PROCESSES \\
\hline 16 & CASTING, MELTING \\
\hline 17 & WELDNG, JONNNG \\
\hline 18 & CLEANING, PRETRBATMENT \\
\hline 19 & PAINTINO \\
\hline 20 & COATING, FINISHING \\
\hline 21 & PLATING \\
\hline 22 & METAL SPRAYING \\
\hline 23 & DRYING, BAKING \\
\hline 24 & LEAT TREATINO \\
\hline 25 & ASSTMBLY \\
\hline 26 & PREHEAI ING \\
\hline 27 & MATERIALS HANDLING \\
\hline 28 & SIZE REDUCTION \\
\hline 29 & AGGLOMERATION \\
\hline 30 & HEATING \\
\hline 31 & MELTINO \\
\hline 32 & ANNBALNO \\
\hline 33 & COOLNG \\
\hline 34 & WATER REMOVAL \\
\hline 35 & SEPARATIONS - SOLID/SOLID \\
\hline 36 & SEPARATIONS - SOLID/LYUID \\
\hline 37 & SEPARATIONS - LUQUD/LQUID \\
\hline 38 & SEPARATIONS - LUQUID/GAS \\
\hline 39 & SEPARATIONS - GASIOAS \\
\hline 40 & SYNTHESLS/CHEMICAL REACTIONS \\
\hline 41 & FABRICATION \\
\hline 42 & SPACB CONDITIONINGMASC \\
\hline 43 & LGHTING \\
\hline 44 & MOLDNG \\
\hline 45 & SEPARATIONS - SOLID/OAS \\
\hline 46 & ELECTRONICS, ELECTROSTATICS \\
\hline 47 & PHOTOCHEMICAL PROCESSING \\
\hline 48 & SMELTING \\
\hline 49 & BLBCTROLYSIS \\
\hline so & MIXING, COMPOUNDNNG \\
\hline 51 & CURNO \\
\hline 52 & SLASHING, BEAMING \\
\hline 53 & WASHWNG, DESIZING, SCOUR \\
\hline 54 & DYENNG \\
\hline 55 & WATER REMOVAL - BULK \\
\hline
\end{tabular}

2.11 
Table 2.7. Pacific Northwest Electric Load-Sharedowns by Industry, Bonneville ISCSC Database, 1988 (\%)

\begin{tabular}{|c|c|c|c|c|c|c|c|c|c|}
\hline SIC & Industry & Motors & Hoating & Ulghting & $A / C$ & Compresston & Retrigeration & Electrochernical & Total \\
\hline 20 & Food and Kindred Products & $\boldsymbol{\theta}$ & 0 & 8 & $\mathbf{s}$ & o & 20 & o & $\boldsymbol{\theta}$ \\
\hline 24 & Lumber and Wood Product & 82 & 0 & 4 & 2 & 2 & 0 & o & 100 \\
\hline 28 & Paper and Alliod Products & 84 & o & $\mathbf{5}$ & 1 & 0 & $\mathbf{0}$ & - & 100 \\
\hline 28 & Chemicals and Allod Products & 25 & 54 & 6 & 2 & 4 & 1 & 7 & $\boldsymbol{\theta 9}$ \\
\hline 29 & Petroloum and Proletiod Industribs & 50 & 30 & $\boldsymbol{6}$ & 2 & 0 & 1 & o & 101 \\
\hline 32 & STone, Clay, and Glass Products & $n$ & 11 & 8 & 4 & 0 & 0 & 0 & 100 \\
\hline 33 & Primary Motals Industrites & 18 & 5 & 5 & 1 & 0 & o & 70 & 8 \\
\hline 37 & Tramaportation Equlpment & 70 & 7 & 18 & 5 & 2 & 0 & - & 100 \\
\hline
\end{tabular}




\subsection{Industrial Electric O\&M Energy Conservation Opportunities and Potential Energy Savings}

This section presents the findings of the literature and data search into potential energy savings through O\&M energy measures. To accornplish this and to establish a commonality with the reader, a working definition for O\&M is presented. Estimates of energy savings and results of case studies, which were identified in the research, are then presented. This information is then correlated to the industrial energy consumption identified in Section 2.0 to establish an estimate of overall energysaving potential for the various O\&M energy measures in the United States and the Pacific Northwest.

\subsection{Defining O\&M}

Before reviewing literature and data sources for energy-savings potential, it is first important to define what is implied through the term O\&M. There are several different categories of maintenance. Fuchs (1993) defines six different categories of maintenance, including preventive maintenance (and predictive), unscheduled repairs, emergency repairs, scheduled maintenance, and routine maintenance activities. In addition, Fuchs defines four categories of non-maintenance, including construction, equipment installation, equipment relocation, and equipment modification. Although these definitions may cover maintenance, none of these terms considers operations.

To assist in developing a working definition for O\&M, PNL utilized the resources of the TAC. After much discussion, the following multifaceted definition resulted:

- an activity that is financed as an expense rather than capital

- a low-cost item that can be installed or performed by the O\&M staff, although it may be contracted; an activity or item that is considered a routine capability

- an item or activity that has a simple payback of less than one year

- any item or activity that will bring the equipment back to its original design and specification; e.g., repair

- a repetitive activity; e.g., preventive and predictive maintenance

- any activity affecting the operation of the equipment, e.g., control settings, set points, schedules, and procedures

The above definition still brings much potential for debate, even among the authors and members of the TAC. Not everybody's definition of O\&M is the same and the reader may consider some measures in the following discussion to be capital items. The reader should note, however, that each energy measure is identified separately and in enough detail that the reader may remove select energy measures and use the information accordingly. 


\subsection{Findings of Industrial Electric O\&M Potential Energy Savings}

Numerous publications were reviewed to identify industrial energy-savings potential through O\&M activities with only moderate success. Although there are a number of publications that contain information such as energy conservation checklists, O\&M activities and O\&M energy impacts, there is very little quantifiable data useful in compiling a picture by industry or end-use. The general problem is that the literature is fragmented and specific information regarding energy savings impact of O\&M activities is very limited. The information that is identified is based mainly on small case studies with limited generalized energy-savings impact of O\&M measures, or it is over-generalized expert opinions, not measured data.

The information obtained is summarized in Table 3.1. This information identifies several O\&M measures and an estimated percent energy-savings potential for each measure. In order to estimate overall energy-savings potential, it is necessary to associate a single end-use category with each O\&M measure. Engineering judgement is used to determine the "best fit" of end-use category to the O\&M measure. From this information and the associated end-use category from Section 2.0, estimates of the national and Pacific Northwest regional electric energy-savings potential are calculated. These estimates are also shown in Table 3.1.

Table 3.1 lists potential energy savings derived from a variety of different sources, ranging from small case studies to expert opinions. There is a significant amount of overlap in categories and duplication of energy conservation measures, often with different reported savings estimates. A second limitation to these findings is uncertainty in determination of the end-use category utilized in the calculations. Because the end-use category chosen as the "best fit" is not always a perfect fit, as referred to in Section 2.5, there is an inherent source of error in the estimates of total energy savings. These are the two principal limitations to Table 3.1. It is significant that the electric energy use categories listed in Table 3.1 are almost all motor related. As shown in Table 2.5 and 2.3, motors account for $64 \%$ of the industrial electric energy consumption in the Pacific Northwest, although on a national level motors account for $72 \%$ of manufacturing electric energy consumption. This difference is due predominantly to the heavy use of electrolytic separation in the aluminum industry in the Pacific Northwest.

Duplication in Table 3.1 exists in the categories of drive systems, lubricants, and compressor controls. For example, of the 32 energy conservation measures listed, five involve improved lubricants for motors alone. The range of savings estimated for this conservation measure varied widely with the different references, covering a range from $0.63 \%$ to $11.5 \%$ of the motor's electric energy consumption. The wide variation makes an accurate savings estimate difficult for this particular O\&M measure. Also implicit in Table 3.1 is the assumption that all motors can use improved lubricants. It is unknown to what extent these improved lubricants have already penetrated the market.

Note also that three measures are aimed at improving the efficiency of belt drives. Lovins (et al. 1989) estimates that $22 \%$ of industrial motor shaftpower is transmitted through belt drives. V-belt drive efficiency typically ranges from 90 to $96 \%$. Lower figures result from belt slippage and from energy dissipated in belt flexing, both of these inefficiencies increase with smaller pulley sizes. Industry estimates suggest that 30 to $60 \%$ of these belt drives are not well maintained. In general, this refers to improper belt tension. Savings from switching to energy efficient v-belts (referred to as 
cogged v-belts) or synchronous belts should be small over a well maintained drive and large over a poorly maintained drive. The use of cogged or synchronous belts is of course mutually exclusive. One laboratory study comparing synchronous belts with well maintained v-belts drives reports a $5.6 \%$ savings using synchronous belts in small, 3 in. pulleys and a $2.0 \%$ savings using 8 in. pulleys (Lovins et. al 1989). The same report suggests that the savings over cogged belts was $3.6 \%$ and $0.5 \%$ respectively. Table 3.1 applies the average of these to all pulleys and to all belt drive systems. In actual practice, the significant savings differences due to the pulley size might make synchronous belts a worthwhile investment only in certain instances, although the savings in maintenance may also make them attractive.

Lead/lag controllers are control devices used in pneumatic or fluid systems where more than one compressor or pump is required and where the air or fluid flow varies. The controls are used to cycle certain compressors (or pumps) in the system on or off in order to keep the working compressors (or pumps) in the system operating at an optimal efficiency and required flow. Thus, the savings potential listed for lead/lag controllers on compressors and pumps is only applicable to systems with multiple compressors or pumps. The fraction of systems that meet this criteria is unknown, however it is not all of the compressor or pump systems.

Fast controllers are lead/lag controllers which also match pressure set points to variable loads and reduce compressor surges. The reported savings potential for fast controllers and lead/lag controllers suggests that much of the savings is implementing a lead/lag effect, and thus only applicable to multiple compressor systems. Because the cost of these controllers are not very dependent on compressor size, they are particularly attractive in large compressor systems.

Repair of leaks in compressed air systems is a very common O\&M issue with good payback. It is labor intensive however, and to keep up with the system it is important that leaks be checked on a regular basis. The savings associated with this measure have been applied to the compressor end-use category taken from Table 2.3 and Table 2.5. As noted in Section 2.5, these tables do not separate air compressors from refrigerant compressors therefore, the savings estimates from this specific example are somewhat overstated. The savings reported for general air compressor O\&M is the result of air compressor audits at four North Carolina industrial plants (Singh et al. 1990). The study estimated that the average savings for manufacturing plants in that state would be $12.6 \%$ of compressor energy.

Most motor O\&M measures involve some type of tune-up of the plant electrical system or better scheduling of the motor use to the application. Controlling phase imbalance or plant supply voltage allows maintenance personnel to consistently improve motor performance throughout the plant. It is important that motors be properly sized for the load and that proper voltage be applied. If a plant uses predominantly dual voltage motors, it may be hard to correct the plants line voltage to achieve an optimum performance. Phase imbalance primarily results from large loads on only one phase of the plants electrical network. Correction requires redistributing these loads across each electrical phase to balance power draw.

The application of the individual electric tune-up measures listed by Lovins suggest a $5.5 \%$ savings, however this is from studies of individual motors. A second source (Naujel et al. 1991) reports a higher savings of $8 \%$. Correcting voltage imbalance between phases on a polyphase motor can significantly improve the motors efficiency. A report by Argonne National Laboratory (1980) suggests that approximately $93 \%$ of U.S. motor energy is consumed by polyphase motors 5 H.P. and greate 
Improved motor use and scheduling, operational changes and improved maintenance practices were lumped together by Smith (1978) as having a total estimated savings of between 2 and 5\% (average 3.5\%). It should be noted that this is lower than the savings predicted by Lovins and Nadel just for electrical tune up measures.

The measures listed can be broken down into those that directly affect the motors such as voltage reduction, those that directly affect the drive system such as using synchronous belts, those that affect the end-use such as compressor controls and cleaning of heating, ventilating, and air conditioning (HVAC) coils, and those that are "group" measures, reflecting the result of an O\&M program. When broken down in this fashion, the results of measures in the first three categories have a interactive, not an additive effect.

For example, a 20\% savings in an air compressor's energy consumption due to the installation of a fast controller results in the compressor system using $80 \%$ of it's original consumption. If cogged v-belts are then used on this compressor and the savings is $2.7 \%$, it is applied to the new energy consumption ( $80 \%$ of original) so that the compressor uses $77.8 \%$ of it's original load (80\% $x$ $[100 \%-2.7 \%])$. Applying correct voltage to the above motor might result in an additional $3.3 \%$ savings so that the compressor would finally use $75.2 \%(77.8 \% \times[100 \%-3.3 \%])$ of it's original energy consumption, not the $74 \%$ predicted by adding the savings independently $(100 \%-[20 \%+$ $2.7 \%+3.3 \%]$ ). Therefore savings estimates from interactive measures should not simply be totaled, although in some cases this may be done to arrive at order-of-magnitude estimates for a plant-wide, regional, or national estimate of potential energy savings.

It is necessary to break the energy conservation measures into these categories to understand their cumulative effect and calculate the actual energy savings possible through an O\&M program. With the "grouped" categories, such as an overall energy management program, experimental results are typically compiled from individual case studies and without knowing the individual measures applied in each study, they are difficult to use as a reference for potential energy savings in other applications. They do have the advantage that if they are representative of an industry, the measured energy savings already take into account the cumulative effects illustrated above.

Of the individual measures listed, the obvious standouts are repair of leaks in compressed-air systems, installation of lead/lag controls on compressors in multiple compressor systems, and general electrical system tune up for motors. The fact that two of these focus on compressed-air systems illustrates the importance of compressed-air management programs. There are still important issues to be resolved on the savings potential because of the use of improved lubricants in motor and motor drive applications, although it is possible that this is also a significant and low cost measure. Lovins (et al. 1989) points out that it can even have a negative cost because the new lubricants may have a significantly longer life than traditional lubricants.

Complete O\&M programs can save a significant amount of the total energy consumption in a facility. The reported savings for school buildings suggests that energy savings can be upwards of 30\% (Lewis 1991). Although application of this percentage to industry, where more of the energy use is in heavy mechanical equipment, may be questionable, it does suggest what is possible. EPRI (Smith 1978) suggests that for mechanical equipment of all types a savings of 10 to $15 \%$ can be expected from O\&M procedures alone. Because most mechanical equipment in industry is driven by motors, this represents a savings potential of 4,715 million $\mathrm{kWh} / \mathrm{yr}$ in the Pacific Northwest and 72,600 million $\mathrm{kWh} / \mathrm{yr}$ in the United States. Because proper O\&M also results in longer equipment 
life, better product output, and improved quality, energy savings can often be achieved at a zero or negative total cost to industry. Accounting for non-energy benefits of O\&M is important to the overall economic evaluation of this potential resource.

\subsection{Energy Analysis and Diagnostic Center Database}

The Energy Analysis and Diagnostic Center (EADC) program has offered no-cost energy conservation audits to industrial plants since 1976. A database of detailed plant and audit information has been maintained since 1980. The database currently resides at Rutgers University (McHugh and Winn 1992). PNL acquired a copy of the database in support of this analysis.

\subsubsection{EADC Background}

EADC is a program funded through DOE. The EADC uses graduate and undergraduate engineering students under the direction of university faculty members to perform energy surveys of small- to medium-sized manufacturing plants. These audits are offered at no charge to the clients. The program began in 1976 with 4 universities acting as centers. The program has since expanded to 22 universities, with plans to expand to 40 by 1998 (Glasser 1992).

To be accepted as an EADC client, manufacturing plants must meet certain criteria, including: 1) annual energy bills less than $\$ 1.75$ million, 2) annual gross sales less than $\$ 75$ million at the plant site, 3) between 50 to 500 employees at the plant site, 4) no on-site energy manager, 5) located within 150 miles of an EADC, and 6) a SIC code between 20 and 39 (Glasser 1992).

These audits generally consist of one- to two-day site visits by an EADC team. The EADC team usually consists of a supervising faculty member and 2 to 4 engineering students. After the onsite visit, the EADC generates a technical report for the client. The report contains a detailed plant and manufacturing process description, a list identifying the major energy consuming equipment, a historical survey of plant energy consumption, and a detailed analysis of cost effective energy conservation opportunities (ECOs). Approximately one year after the report is complete, the client is contacted to participate in an implementation survey. This information is then added to the EADC database.

\subsubsection{Database Description}

The database contains information from over 2,400 audits conducted from 1980 to 1990 from 16 EADCs and includes data on over 15,600 specific energy conservation recommendations. The energy conservation measures in the database are identified by codes from the Directory of Industrial Energy Conservation Opportunities (DIECO). (a) PNL, with assistance from the TAC, classified 80 DIECOs as electric O\&M energy-saving measures; these are listed in Table 3.2. The EADC database contains over 5,500 records (over $35 \%$ ) pertaining to electric O\&M measures.

(a) DIECO is a listing of standard industrial efficiency measures developed by the University City Science Center in Philadelphia. 


\subsubsection{Advantages and Limitations of the Database}

The EADC database has several advantages and limitations as it pertains to this analysis. The most important advantage is that the EADC database is reported to be the only database consisting of ECOs for a full range of DSM measures (including fuel switching) based on actual energy audits. The database also contains a large sample from several geographic locations and includes all but one industry group (SIC 21 - Tobacco Manufacturers). The database also contains considerable information on the facility, its baseline, fuel types, as well as the individual ECO information, including implementation data.

There are, however, some limitations to the database. The most important of these is the client base itself, small- to medium-sized plants. Application of the EADC data to large facilities, as is done in this analysis, will likely introduce some error. Larger facilities, while fewer in number, consume a majority of energy within the manufacturing sector. Larger facilities are sometimes assumed to be more efficient and have improved control over their energy consumption. If this is the case, application of the EADC database to larger facilities may tend to over estimate the potential energy savings. This hypothesis, however, has not been tested.

Another limitation of the database is that while the database includes data for several fuels, including electricity, it does not contain data on electric demand. In addition, although the database is based on actual energy audits, energy savings are based on engineering estimates, not metered data. Finally, the baseline energy consumption in the database is for the entire plant, not for end-use.

\subsubsection{Database Analysis}

The results of the database analysis are shown in Tables 3.3 through 3.10. Table 3.3 identifies the number of plant audits performed by the 16 EADCs included in the database by industry SIC (2digit). This information is illustrated in Figure 3.1. The information by four-digit SIC is available in the database, but would be two large to present here. As can be seen, some industries are better represented than others. There are few audits in SIC 29 (Petroleum Refining and Related Industries) and SIC 31 (Leather and Leather Products). In the case of SIC 31, there may be few plants within the operational limits of the EADCs or a small population in general. Therefore, the sample size may still be acceptable. With SIC 29, the reason for the small sample size is probably attributed to the limitations of the EADC, which limits it to small- to medium-sized plants that can be adequately covered in a one- to two-day site visit. With the sample size a small percent of the industrial population, the statistical significance of the data is reduced.

Table 3.4 identifies the number of recommendations (ECOs) made for each of the electric O\&M DIECOs by each industry SIC. This information is also illustrated in Figure 3.2. From this information, certain DIECOs stand out throughout all industry categories. Figure 3.3 illustrates the total number of recommendations made for all industry by DIECO. Twelve DIECOs stand out as the most common recommendations. Figure 3.4 illustrates the total number of recommendations made by industry SIC. This graph is more attributed to the number of audits performed rather than any trend.

For a recommendation to be made and included in an EADC report, and therefore in the database, it must first be applicable to the plant, second not already exist, and third be cost effective for the plant (generally a simple payback of 3 years or less, although there may be exceptions). 
Assuming that the EADC attempts to be as thorough and complete as possible, by dividing the number of recommendations in each category by the number of audits performed in that category, a frequency results. Table 3.5 shows this frequency. This is an estimate of the number of times a DIECO may be found to be applicable and cost effective to an industry category. This should not be interpreted as a market penetration, but rather a market potential. Not all EADC recommendations are implemented. The frequency analysis of Table 3.5 is illustrated in Figure 3.5. Here it shows that certain DIECOs stand out as being the most frequent throughout industry. This is better illustrated in Figure 3.6 which shows the frequency for all industry by DIECO.

Energy savings is, of course, an important criteria. Table 3.6 shows the energy savings as a percent of the plant's total electric consumption for each DIECO and each industry SIC. This information is illustrated in Figure 3.7. Figure 3.8 illustrates the percent energy savings for each DIECO averaged across all industry.

Although some DIECOs do stand out as large energy savers, as noted earlier not all DIECOs are applicable in all plants. Table 3.7 combines, through multiplication, the frequencies of Table 3.5 with the percent energy savings of Table 3.6. (For example, if a specific energy measure saves an average $8 \%$ of a plant's energy consumption within a specific industry category and is only applicable $25 \%$ of the time [1 in 4 plants within that industry category], then the overall potential savings to that industry category is only $2 \%$ [8\% $\times 25 \%])$. The result, Table 3.7 , is an estimate of the electric O\&M energy conservation potential as a percent of total plant electric energy consumption. This information is illustrated in Figure 3.9. Figure 3.10 illustrates this information averaged across all industry for each DIECO. As illustrated in this figure certain DIECOs have a more significant energy-saving potential. Figure 3.11 illustrates the electric O\&M energy conservation potential for industry as a percent of the total electric energy consumption for each 2-digit SIC.

The database also includes implementation data collected after the clients have had time to respond to the reports and their recommendations. Table 3.8 shows the average estimated implementation cost per $\mathrm{kWh}$ for each DIECO in each industry SIC. This information is based on those ECOs actually implemented, or scheduled for implementation, not the entire database. The numbers, however, are still based on calculated estimates, not metered data or actual costs.

The implementation data can also be used to estimate the potential market penetration of individual DIECOs within the various SICs. Glasser (1992) identifies that implementation rates do vary between SIC categories from 71.2\% in the Chemical and Allied Products industry (SIC 28) to $22.9 \%$ in the Lumber and Wood Products industry (SIC 24). Implementation rates were not performed for this analysis, because the EADC data consists mostly of individual efforts on behalf of the plant, usually not due to utility DSM program incentives. The existence of an applicable utility DSM or other technical assistance program should improve the resulting implementation rate.

\subsubsection{Application at the National Level}

Applying the potential energy-savings estimate from Table 3.7 to the national electric energy consumption estimate from Section 2.1, results in the estimate of the national electric O\&M energy conservation potential shown in Table 3.9 and illustrated in Figure 3.12. The spikes shown in Figure 3.12 indicate significant potential for energy savings for certain DIECOs and SICs. Figure 3.13 illustrates the national electric O\&M energy conservation potential for the various DIECOs totaled 
across all industries. Here it is evident that a few DIECOs account for the majority of the total potential energy conservation that can be achieved through O\&M techniques. Figure 3.14 illustrates the national electric O\&M energy conservation potential for the various industry SICs totalled for all DIECOs. In this figure three industry categories stand out - SIC 28 (Chemicals and Allied Products), SIC 33 (Primary Metals Industry, and SIC 26 (Paper and Allied Products). This is no major revelation since these industries are the most significant energy consumers (a small percent of a large number is still a large number). The total potential may be overestimated, however, because of the limitations to the EADC data described earlier.

Combining the electric O\&M energy conservation potential of Table 3.9 with the implementation cost of Table 3.8 results in a supply curve estimate of national energy conservation potential for industrial O\&M opportunities as shown in Figure 3.15. This type of supply curve shows the average implementation cost (first cost) versus the annual energy conservation potential (annual savings). Because useful life and persistence of the measure can not be readily assumed, the cost and savings in this figure are not levelized. The result indicates an energy-savings potential of approximately 80 billion $\mathrm{kWh} / \mathrm{yr}$ (annual savings) with an implementation cost (e.g., one-time repair cost) of $\$ 0.05 / \mathrm{kWh}$ and less.

\subsubsection{Application to the Pacific Northwest}

The information of Table 3.7 can also be applied to the electric energy consumption estimate of the Pacific Northwest presented in Section 2.3 resulting in a regional estimate of the industrial electric O\&M energy conservation potential. This information is presented in Table 3.10 and illustrated in Figure 3.16. It is important to note that SIC 3334. Primary Aluminum Industry, is excluded from the baseline. Although the aluminum industry is the largest energy consumer in the Pacific Northwest. that industry is not represented in the EADC database. It is assumed that the results of the EADC analysis for SIC 33 are not representative of the primary aluminum industry (SIC 3334) without introducing a source of significant error.

The spikes illustrated in Figure 3.16 identify the potential for significant energy conservation for specific DIECOs in specific industry categories. The energy conservation potential for each DIECO across all industry SIC codes is illustrated in Figure 3.17. As with the national level analysis, it is evident that a few DIECOs account for the majority of the energy conservation potential. The energy conservation potential for each industry category across all electric O\&M DIECOs is illustrated in Figure 3.18. A bit of trepidation should be used in interpreting this illustration. Although SIC 26 (Paper and Allied Products) stands out above the other industry categories, there are a number of mitigating circumstances. First, the paper industry is a major energy consumer in the Pacific Northwest, therefore it may stand to reason that it would also have a large energy conservation potential. However, the paper industry in the Pacific Northwest is very active in improving energy efficiency and reducing waste through active energy programs. Second, the paper industries consist of mostly large facilities. These two factors are potentially in conflict with the limitations noted for the EADC database and are therefore suspect.

Combining the electric O\&M energy conservation potential of Table 3.10 with the implementation cost of Table 3.8 results in a supply curve estimate of energy conservation potential in the Pacific Northwest for industrial electric O\&M opportunities as shown in Figure 3.19. As with Figure 3.15, this type of supply curve shows the average implementation cost (first cost) versus the 
annual energy conservation potential (annual savings). Because useful life and persistence of the measure can not be readily assumed, the cost and savings in this figure are not levelized. The result indicates an annual energy-savings potential of approximately 4.0 billion $\mathrm{kWh} / \mathrm{yr}(456.6 \mathrm{aMW})$ with an implementation cost (e.g., one-time repair cost) of $\$ 0.05 / \mathrm{kWh}$ and less. (For purposes of example, assuming each energy measure in Figure 3.19 has a useful life of three years, 100\% persistence over its useful life, no incremental O\&M costs, and using an $8 \%$ discount rate, the 4.0 billion $\mathrm{kWh} / \mathrm{yr}(456.6 \mathrm{aMW})$ could be realized with a levelized cost of $\$ 0.0194 / \mathrm{kWh}$ and less.)

The DIECO list used in this analysis can be grouped into larger categories of end-use equipment as shown in Table 3.11. This analysis indicates that the largest source of electric O\&M energysavings potential exists with air compressors, followed by motors, lighting, HVAC, and controls. 


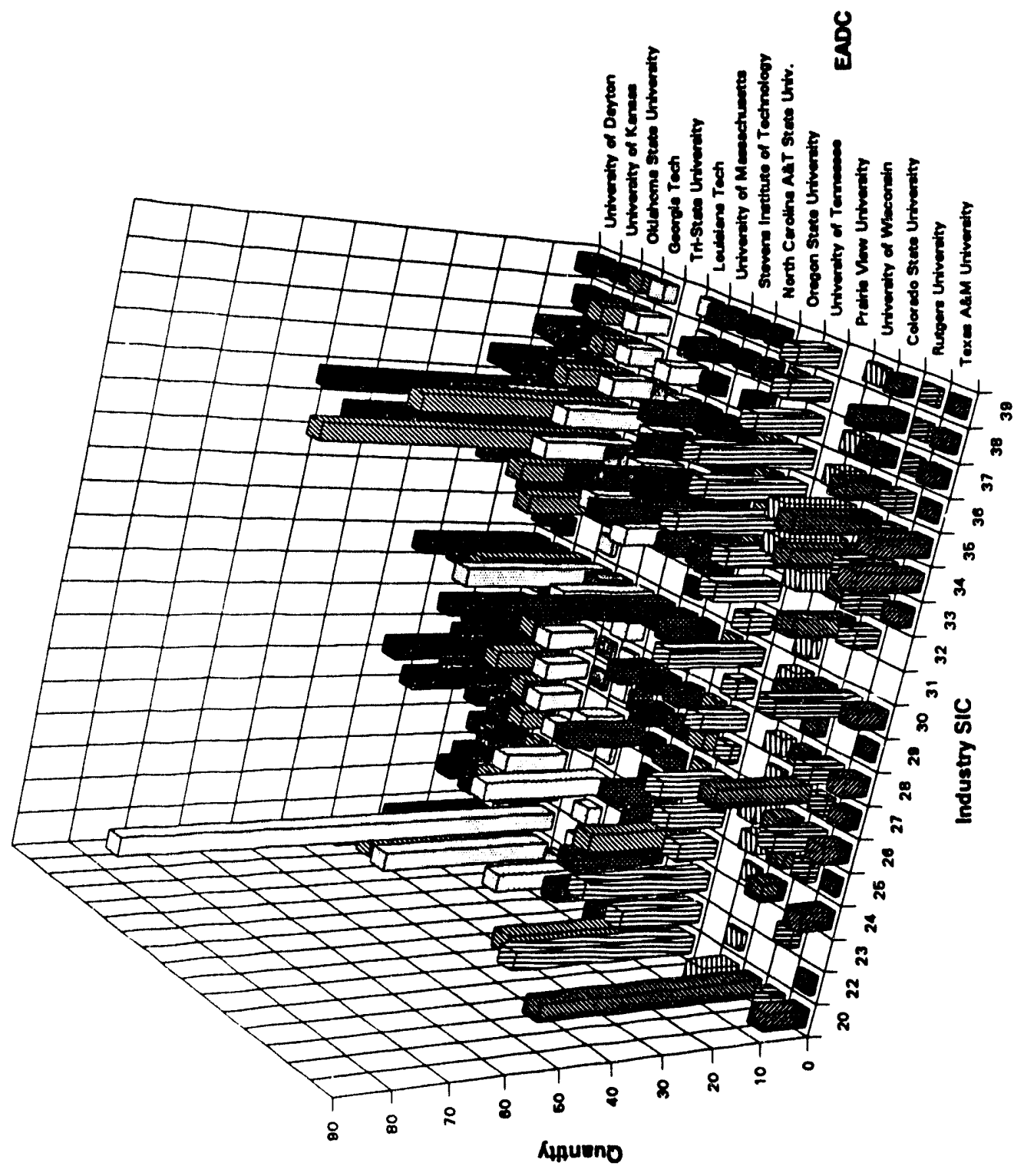

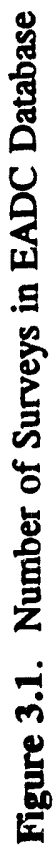




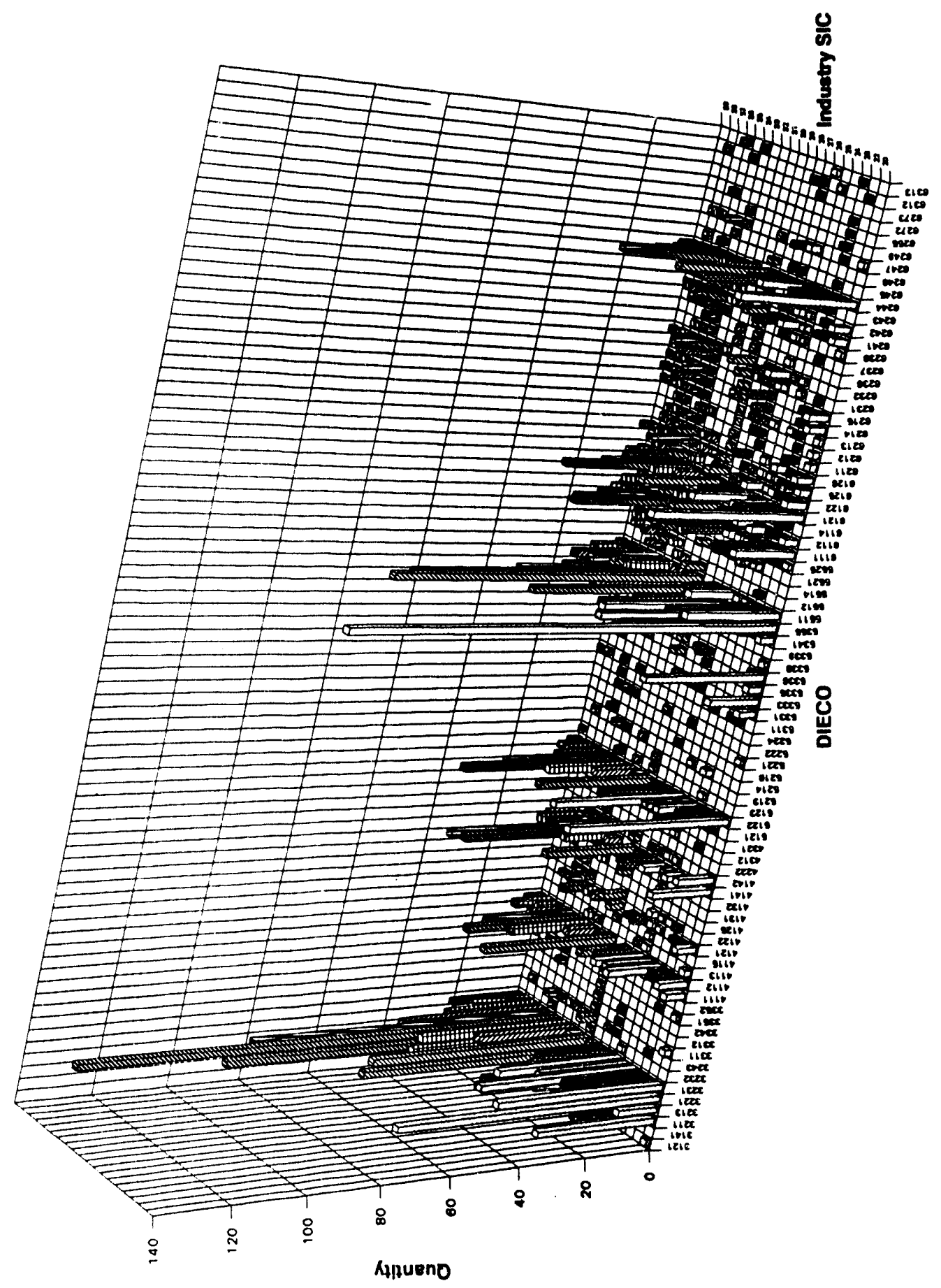

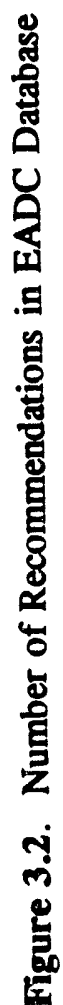





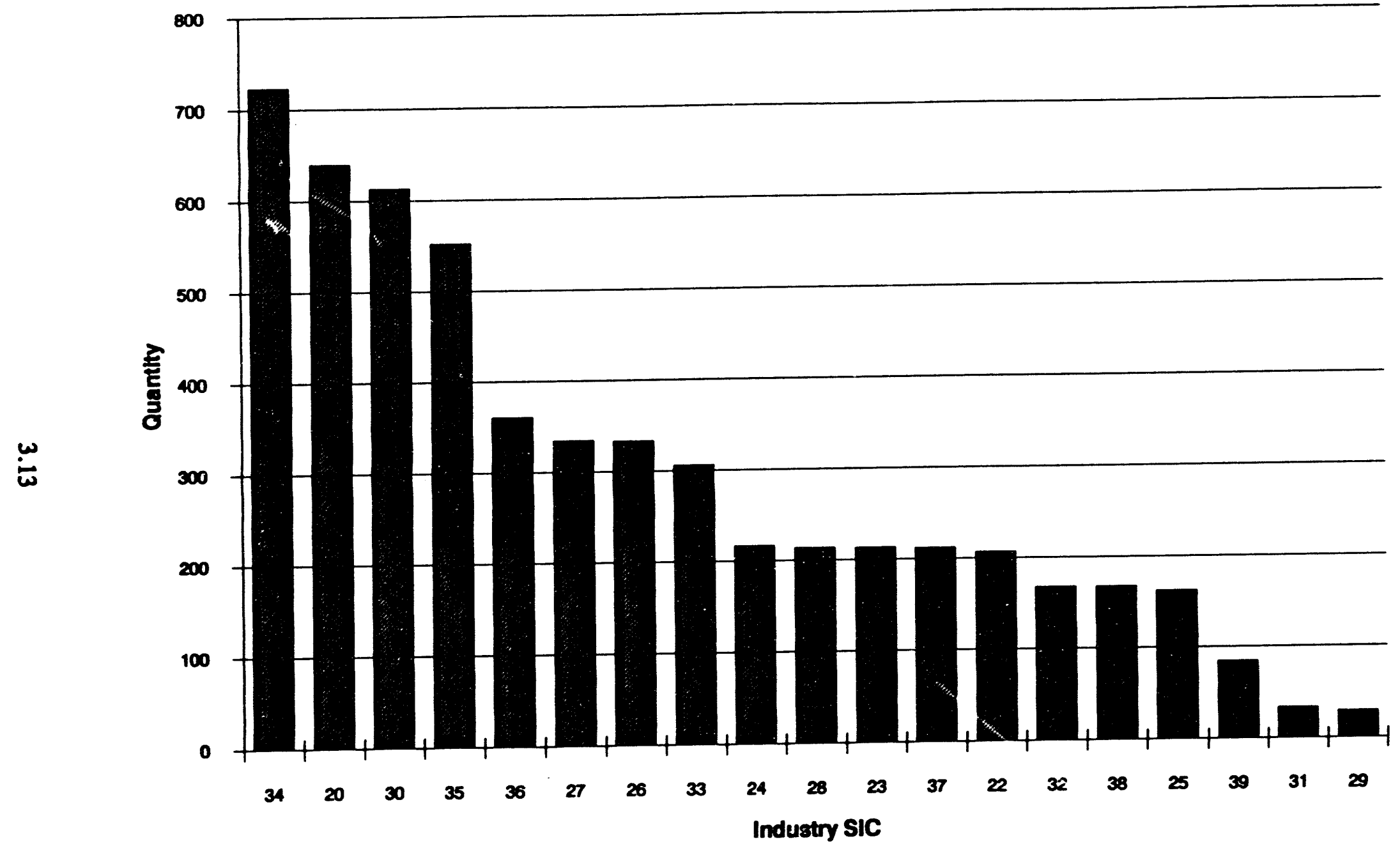

Figure 3.4. Number of Recommendations by SIC in EADC Database 


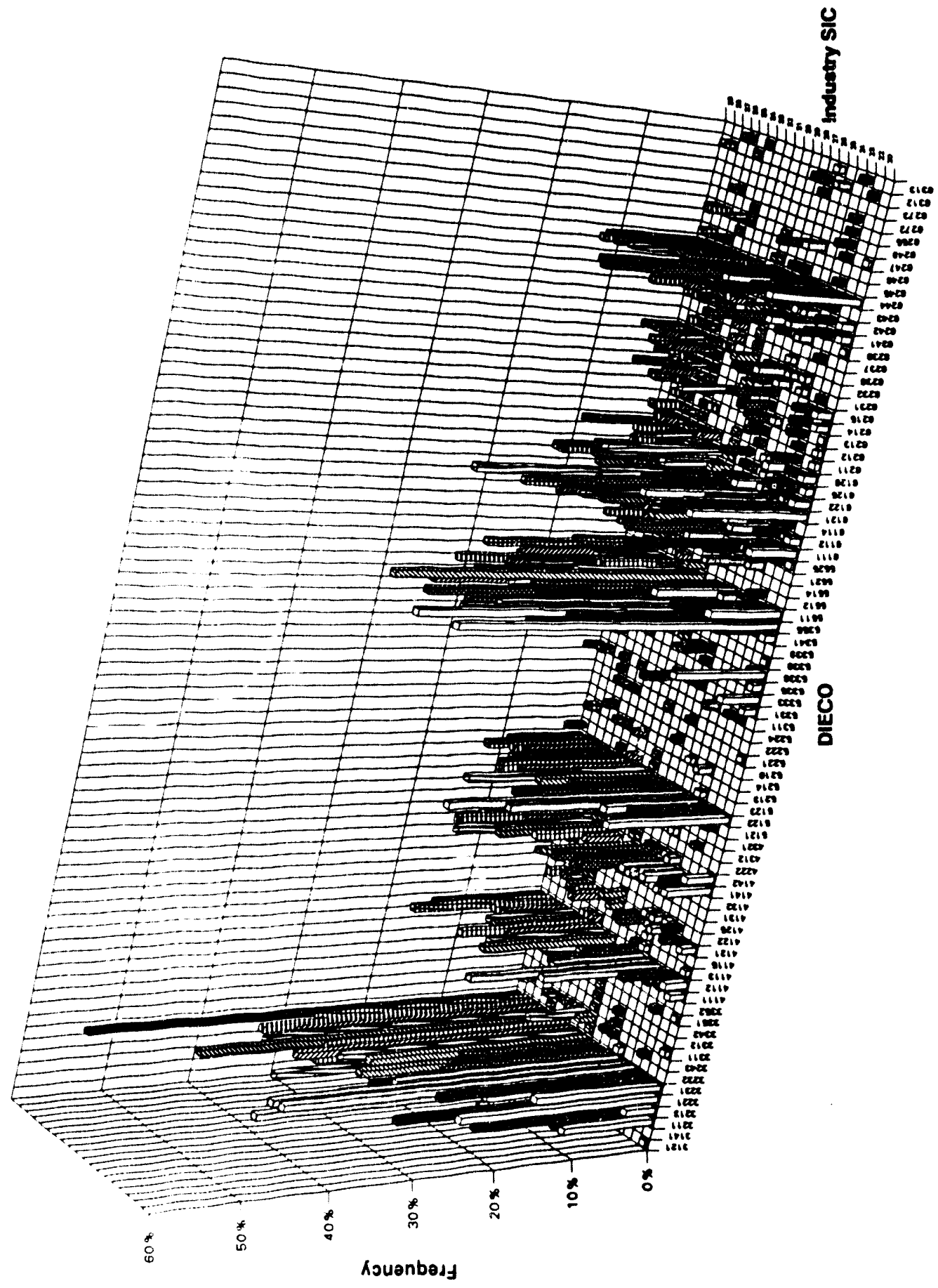

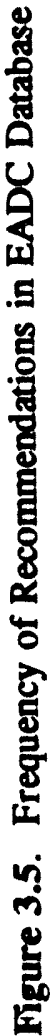




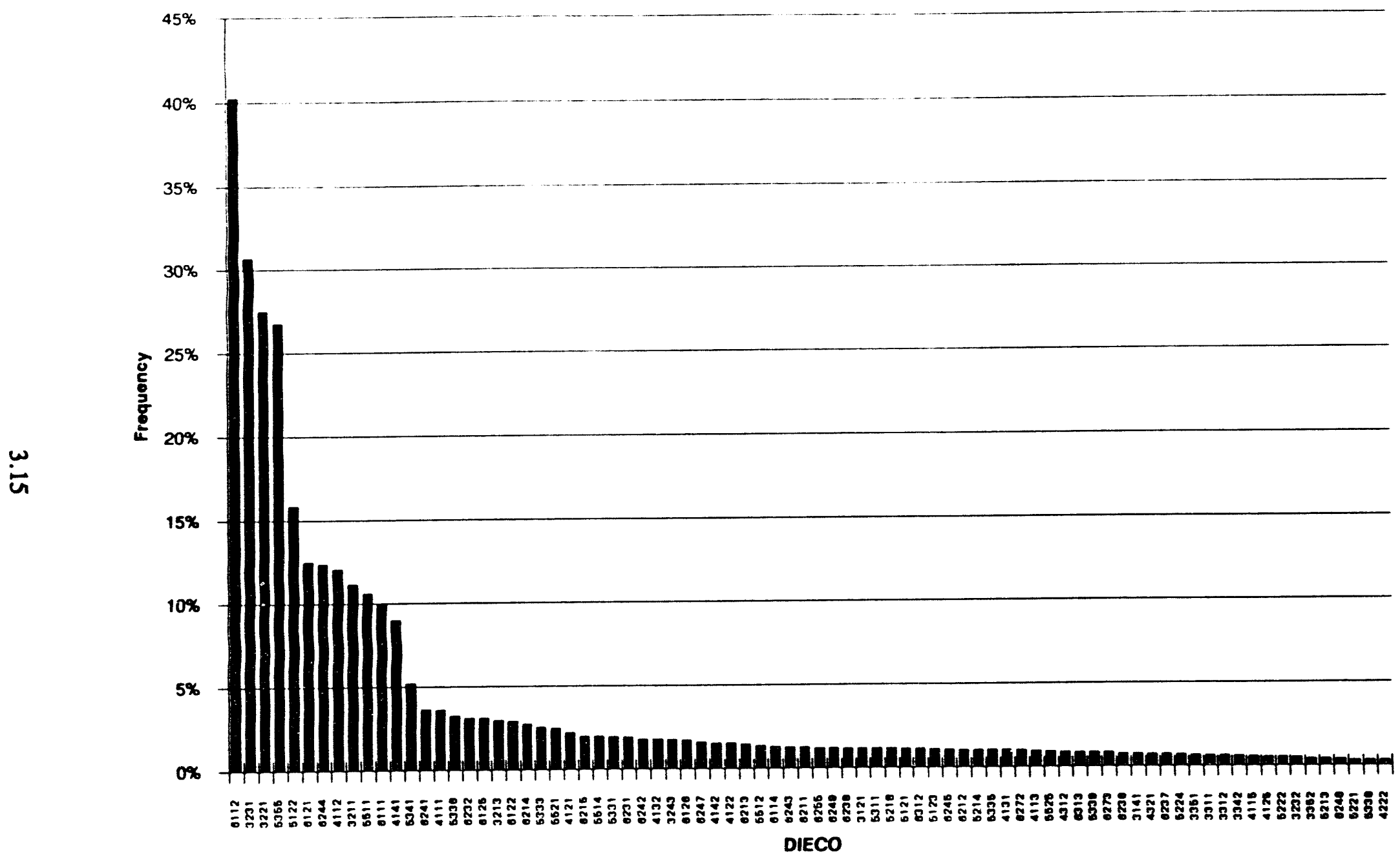

Figure 3.6. Frequency of Recommendations by DIECO in EADC Database 


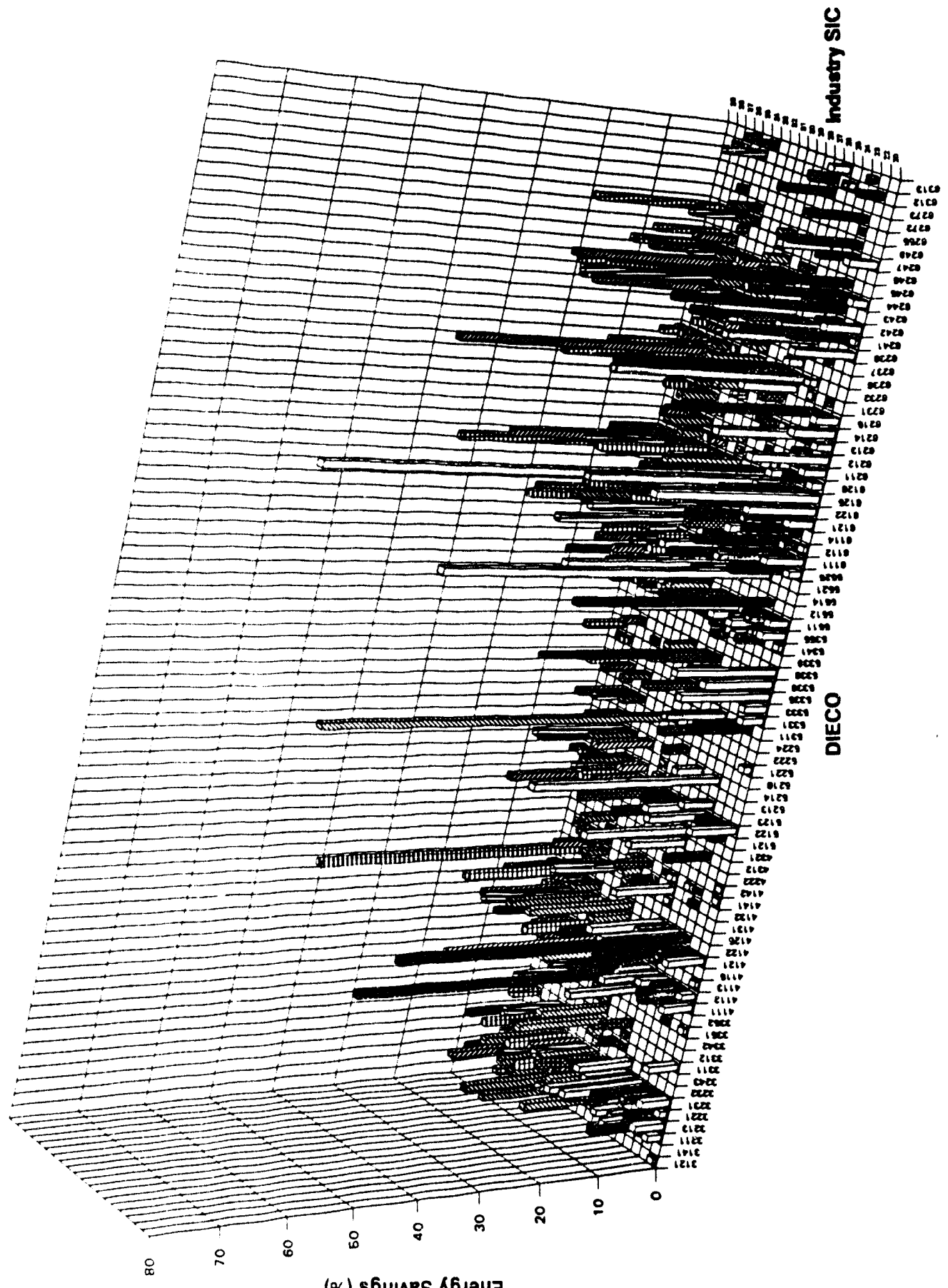

ช్

(\%) s6u!ars K6 


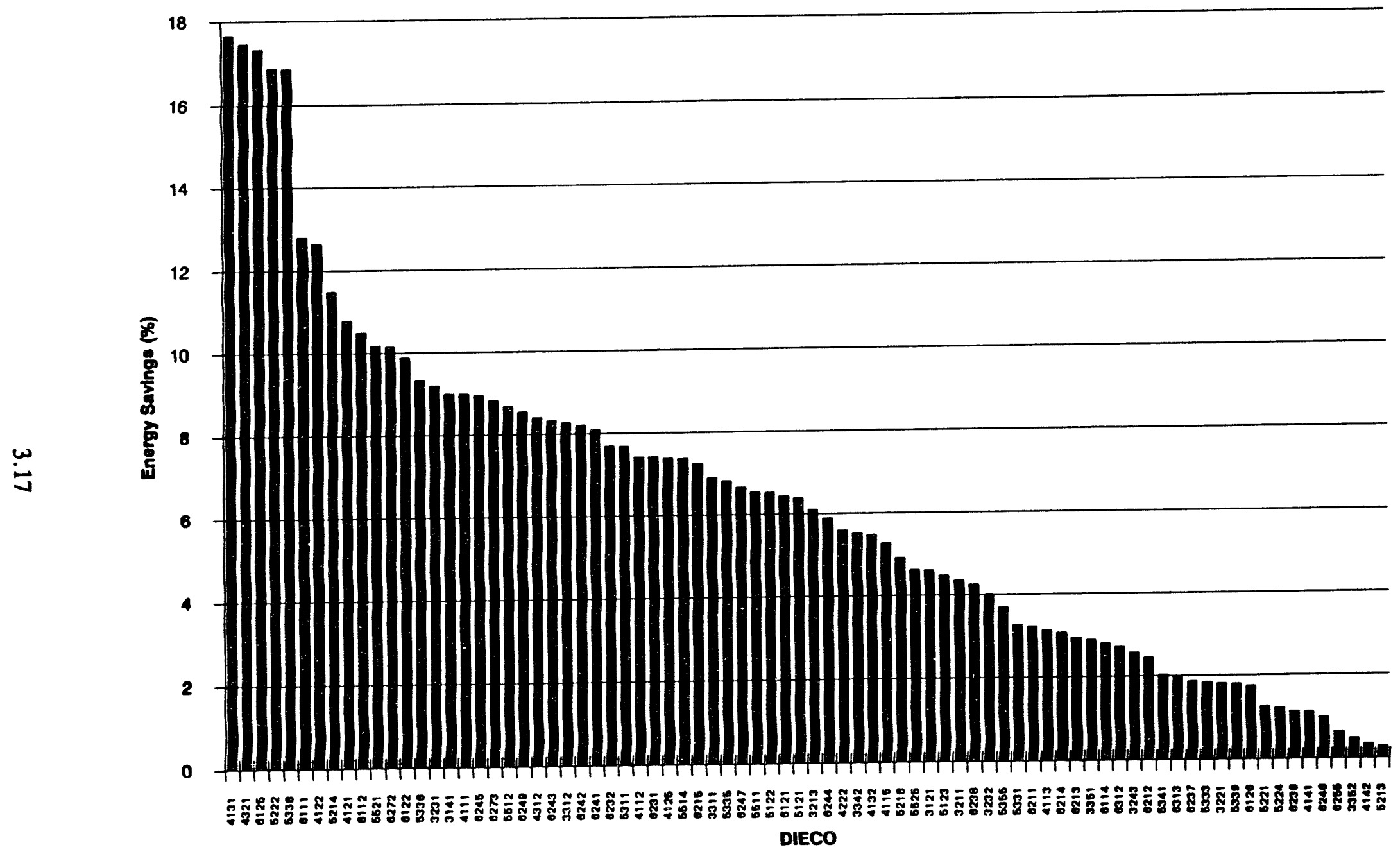

Figure 3.8. Average Energy Savings by DIECO Identified in EADC Database 


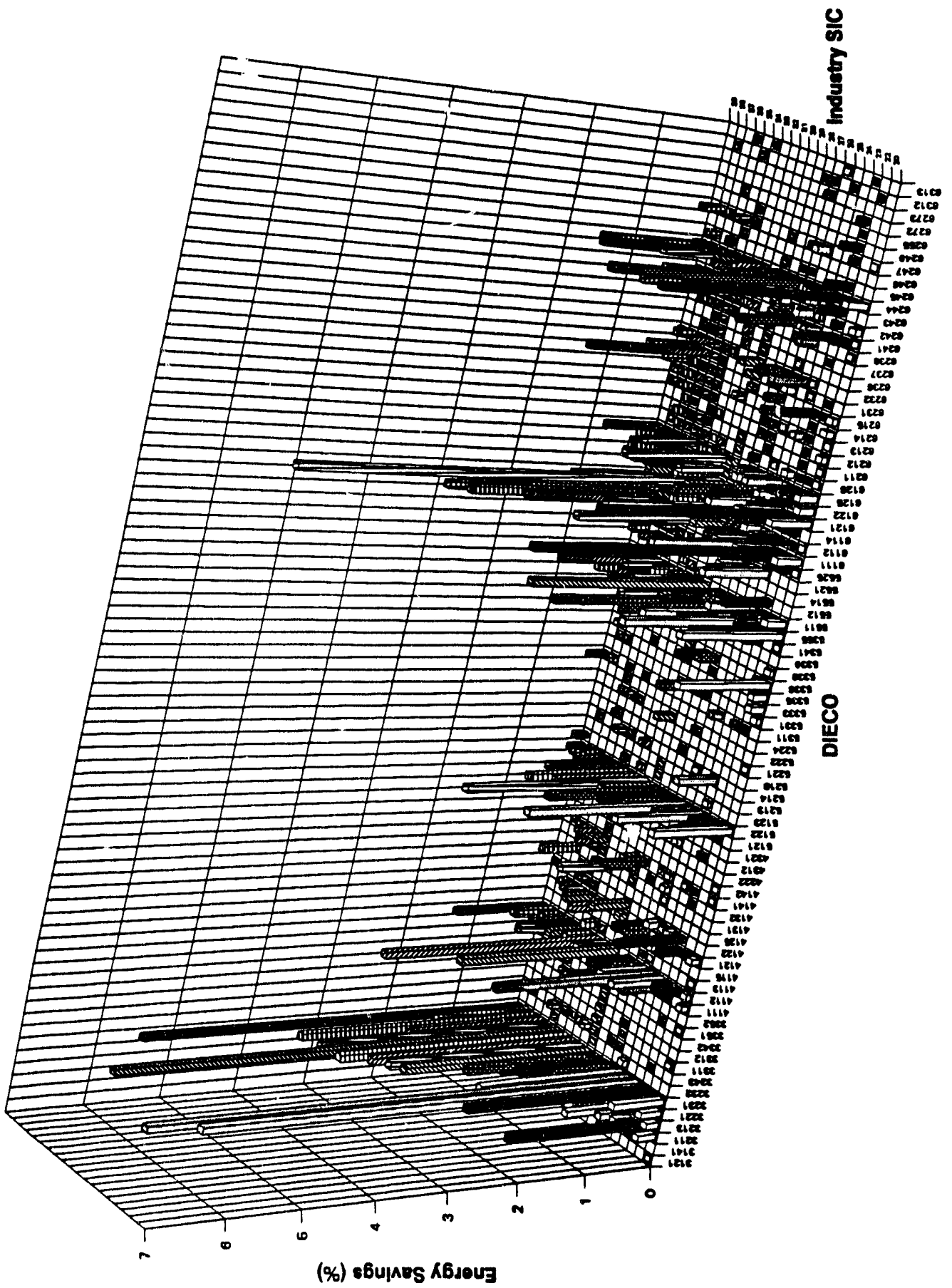

胥 


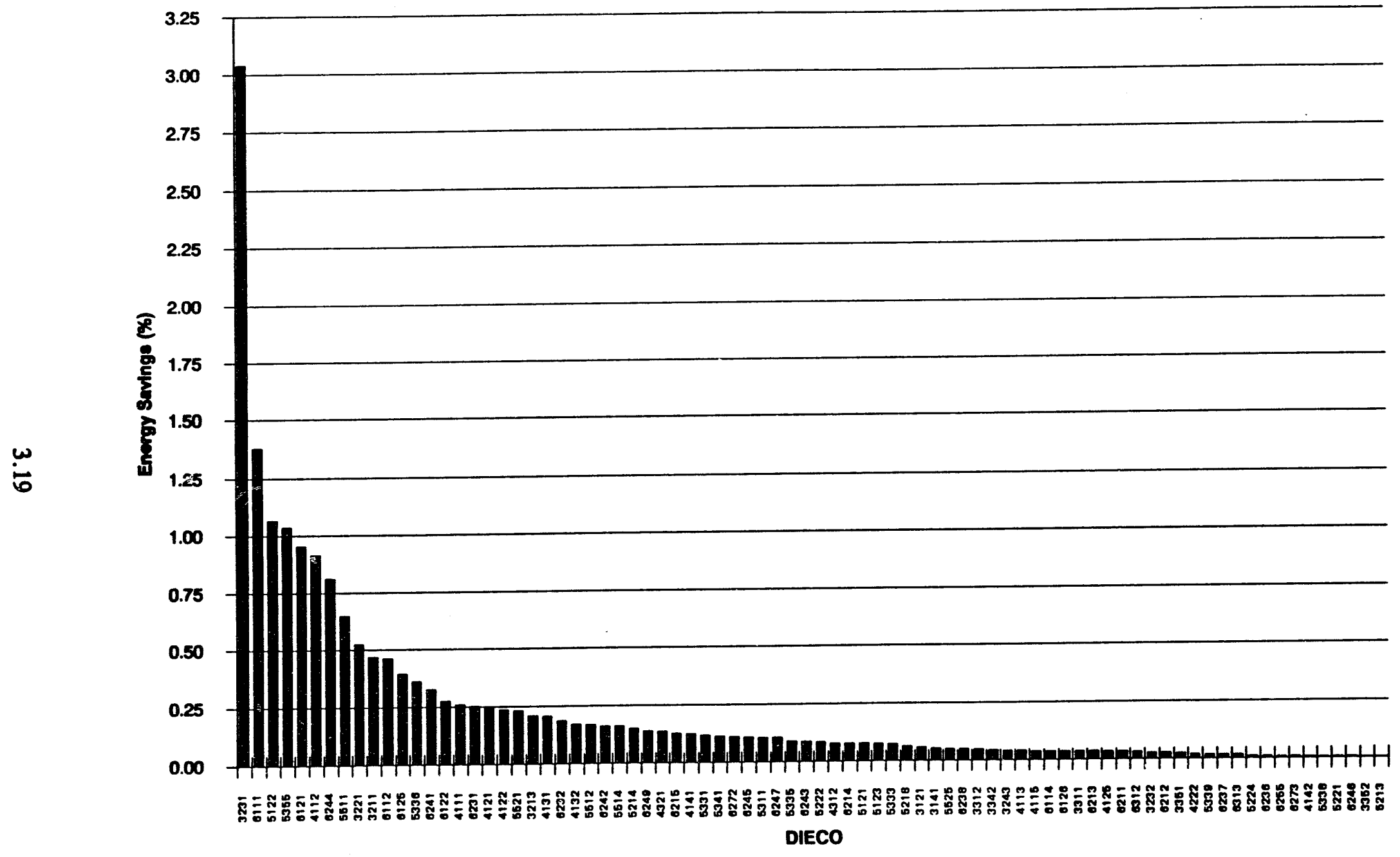

Figure 3.10. Summary of Energy-Savings Potential by DIECO 


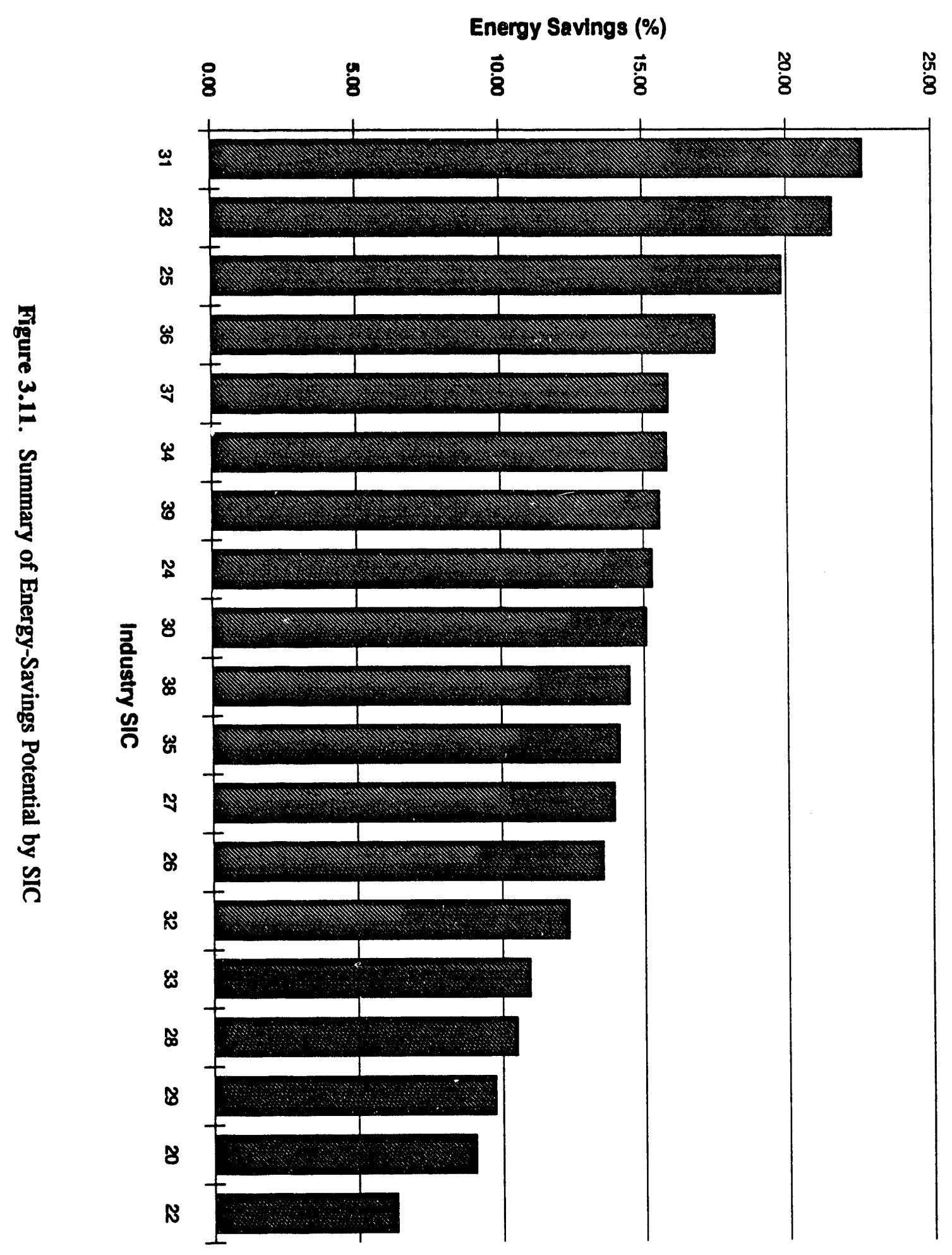




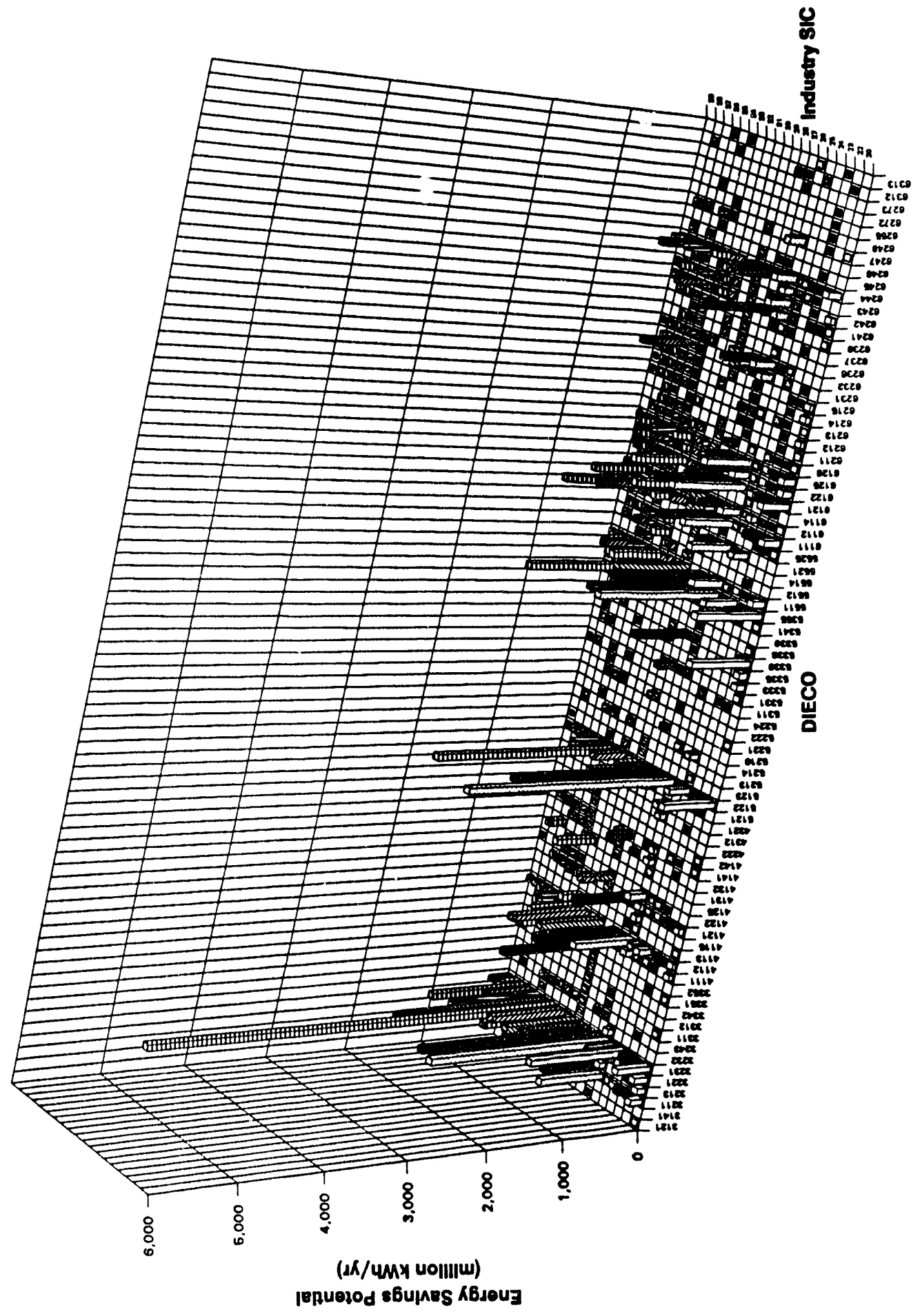

콜 


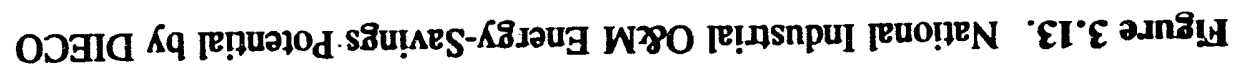

00310

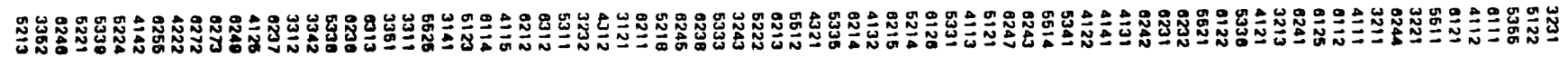

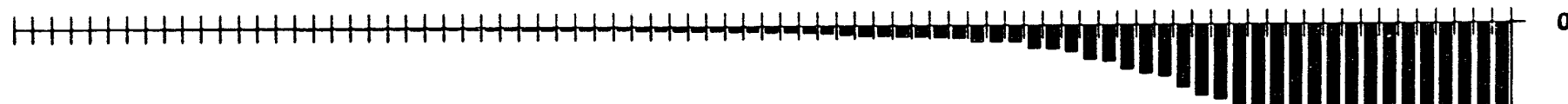

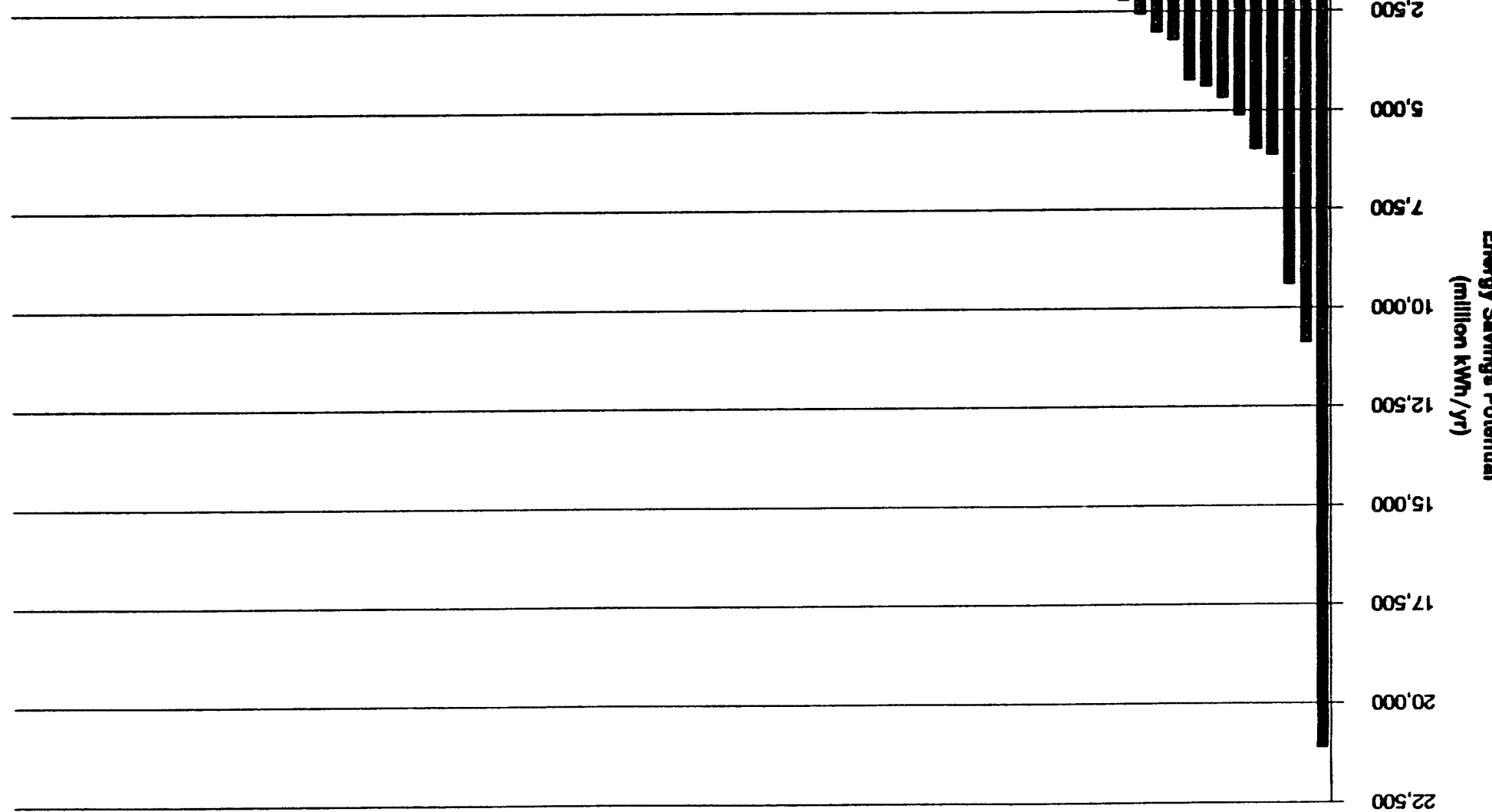




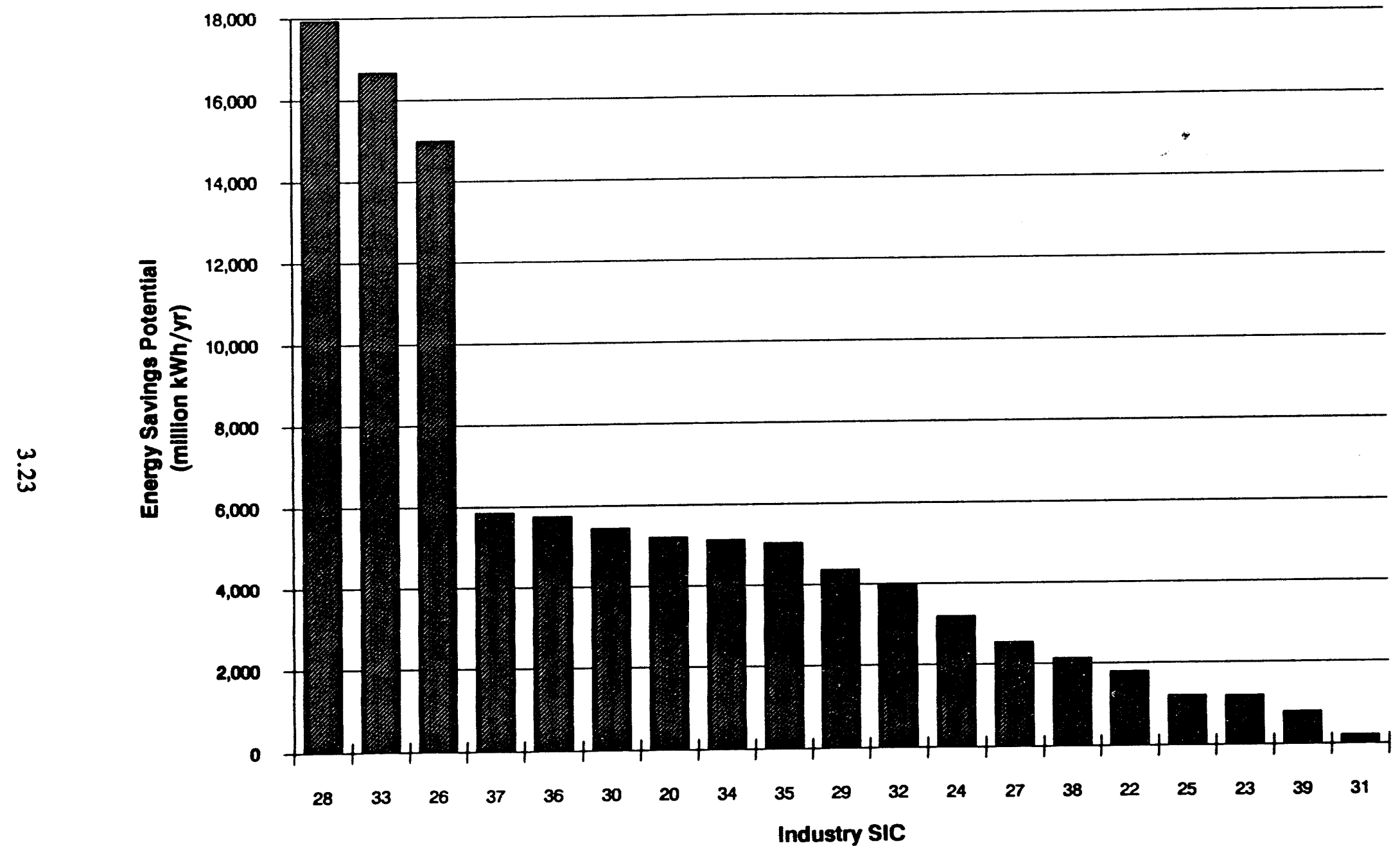

Figure 3.14. National Industrial O\&M Energy-Savings Potential by SIC 


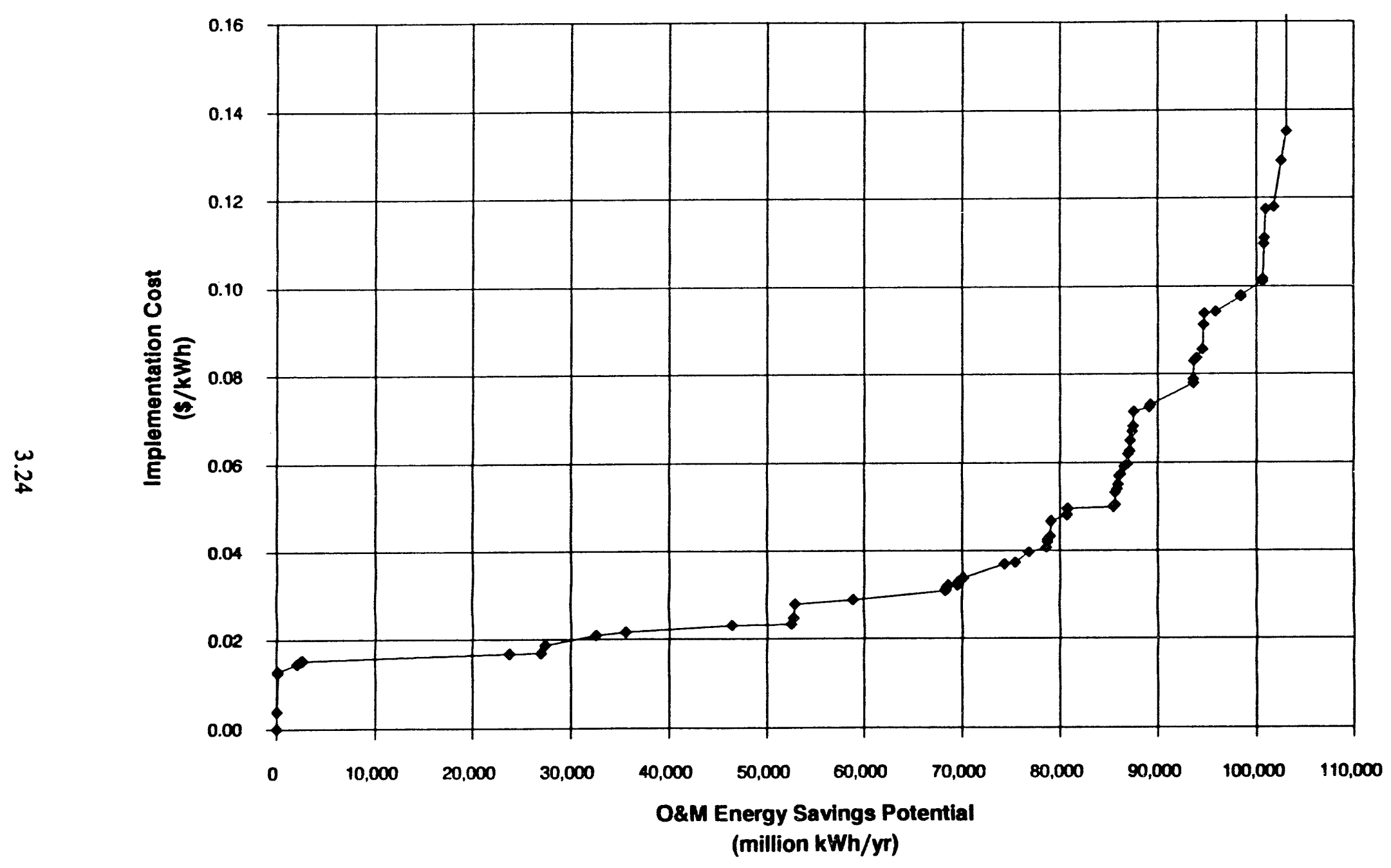

Figure 3.15. Supply Curve of National Industrial O\&M Energy-Saving Measures 


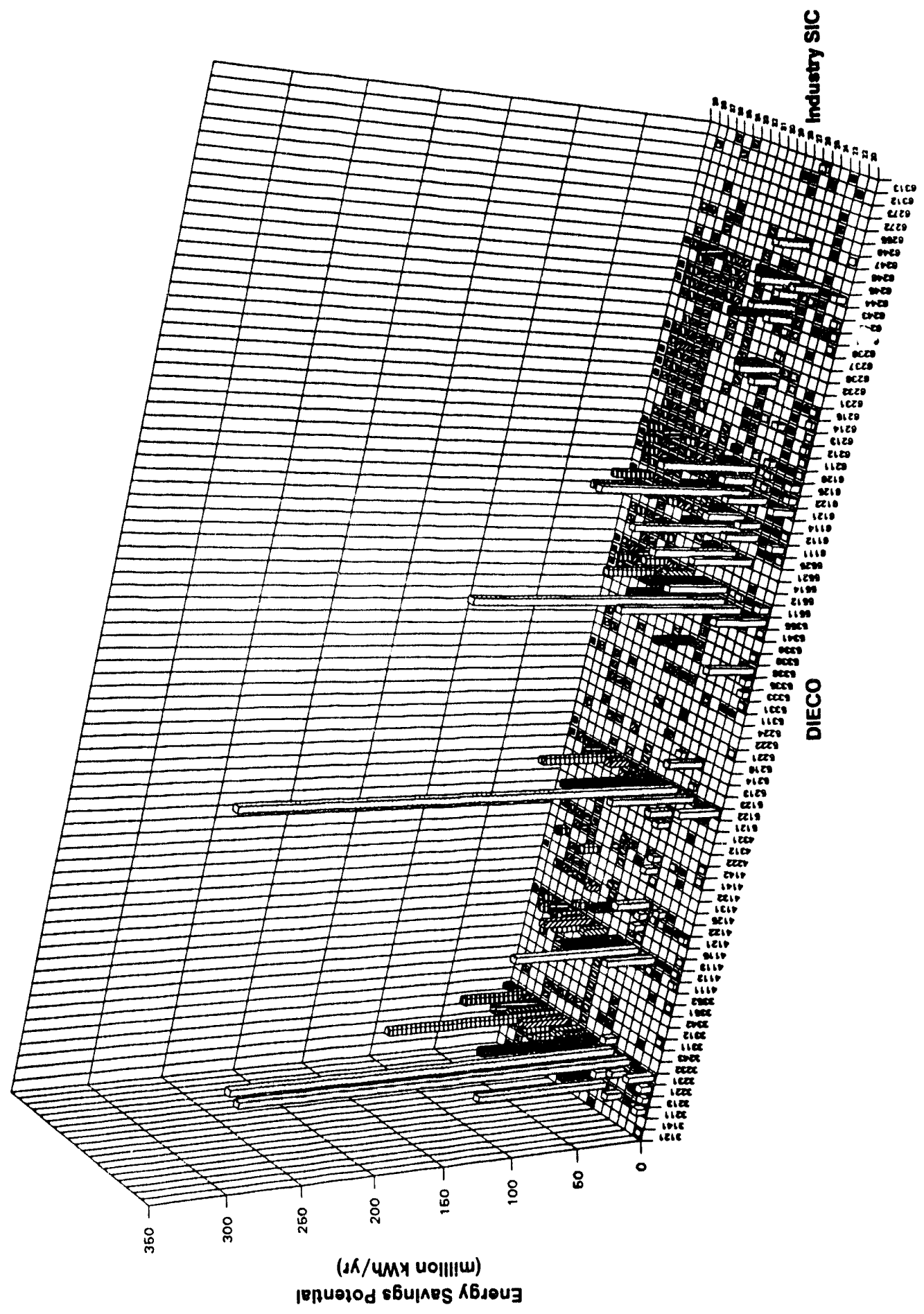

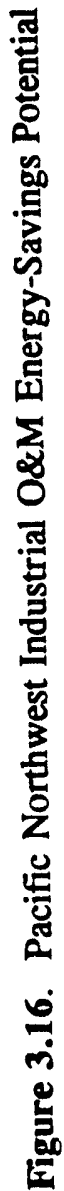




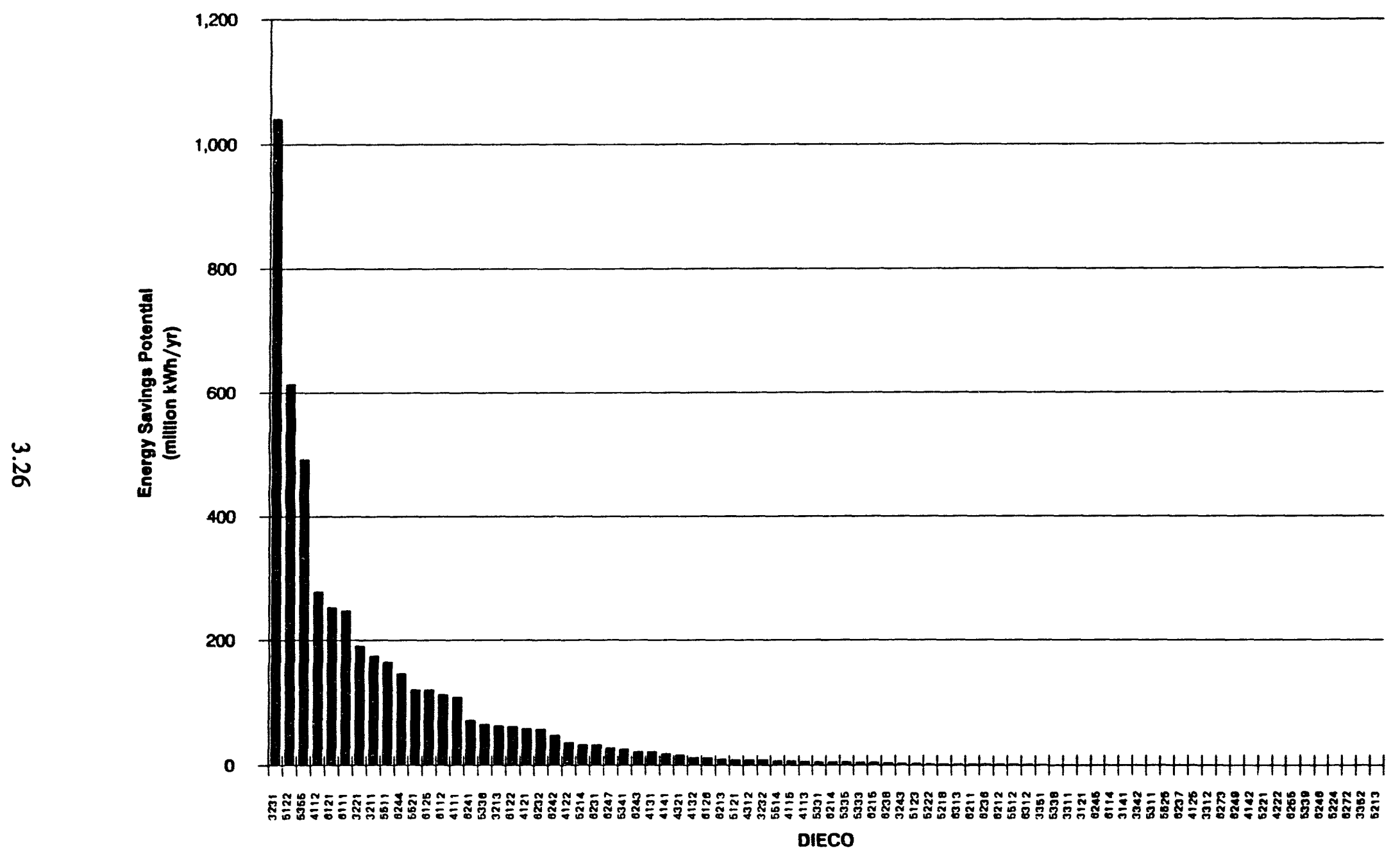

Figure 3.17. Pacific Northwest Industrial O\&M Energy-Savings Potential by DIECO 


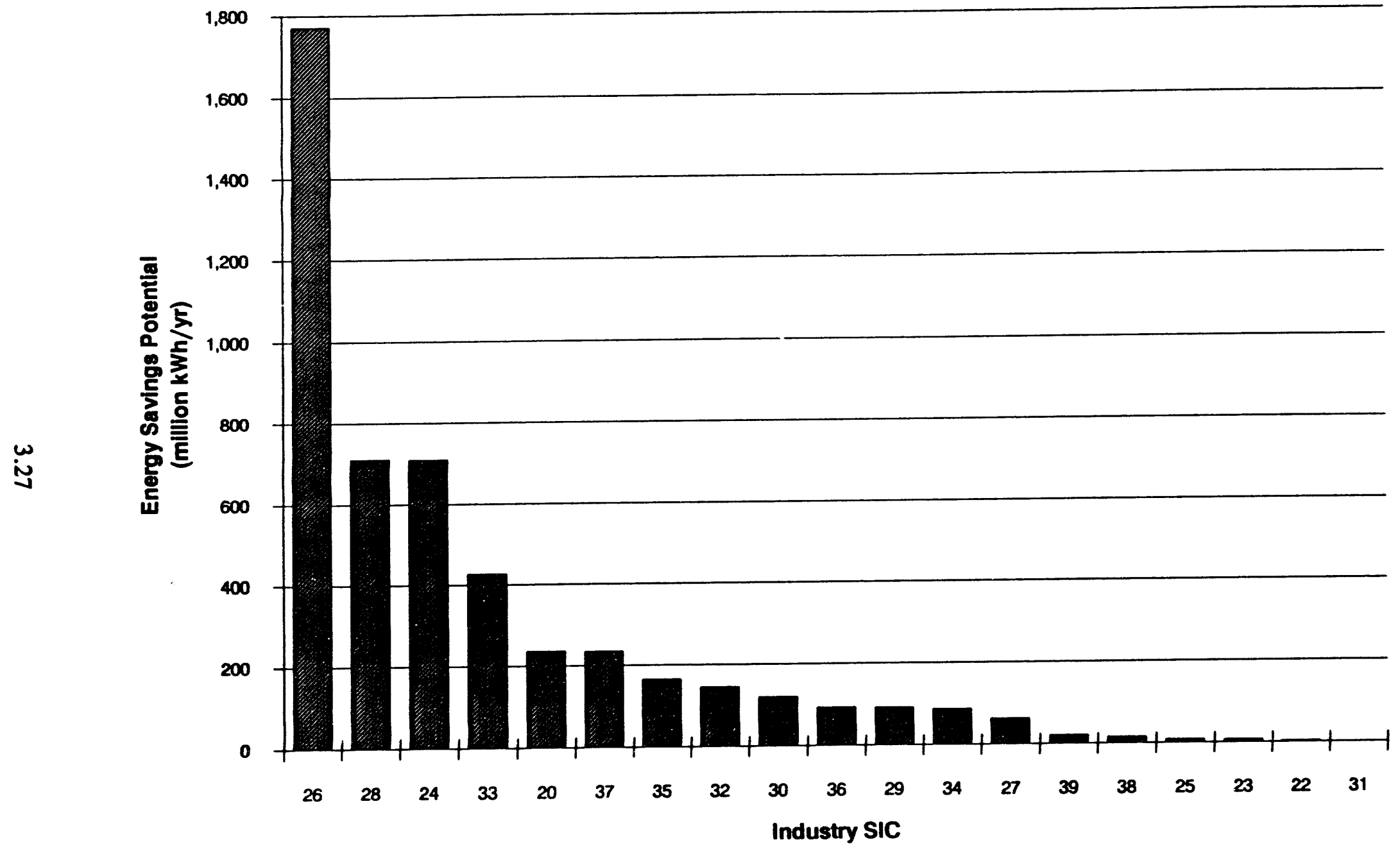

Figure 3.18. Pacific Northwest Industrial O\&M Energy-Savings Potential by SIC 


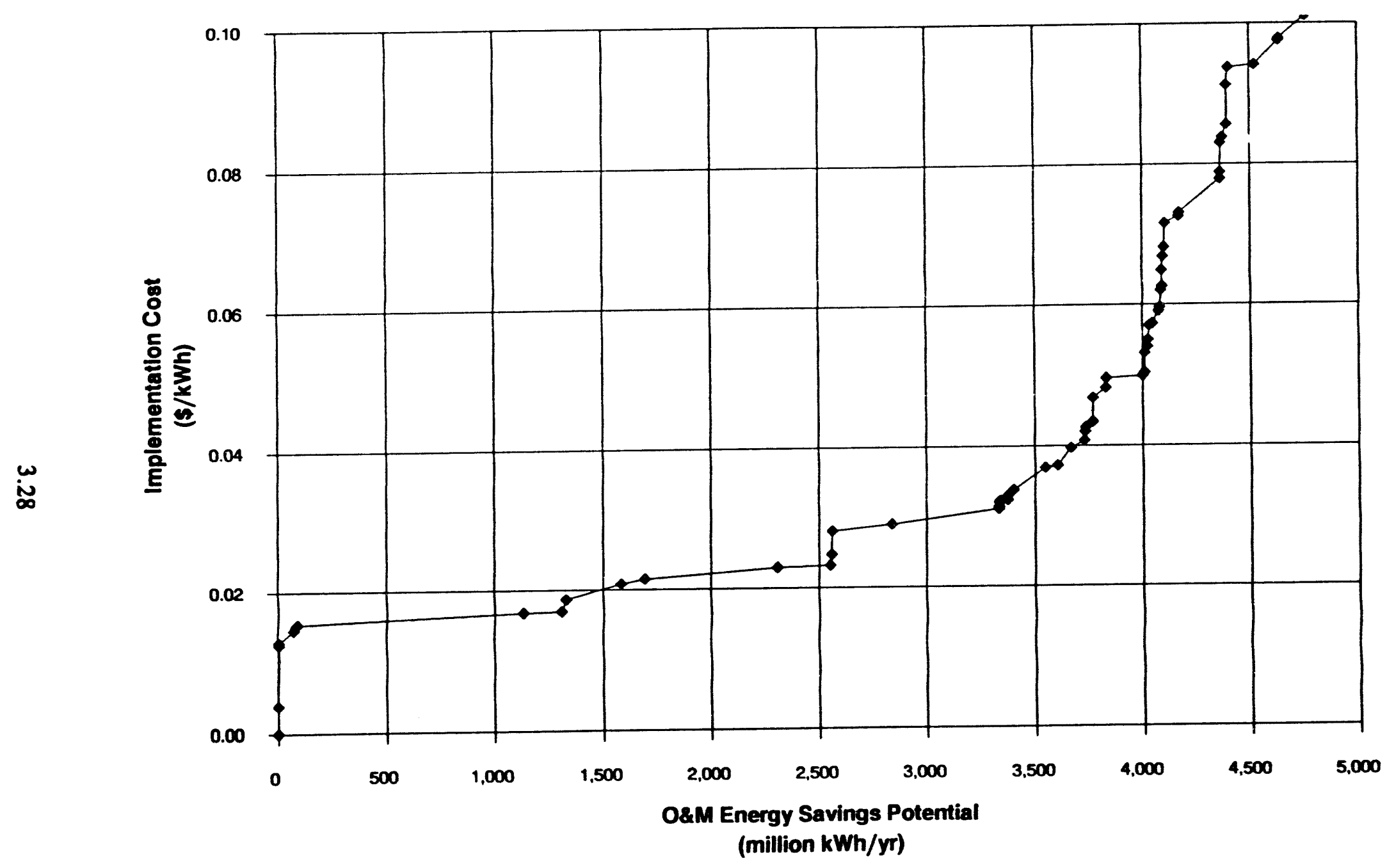

Figure 3.19. Supply Curve of Pacific Northwest Industrial O\&M Energy-Saving Measures 
Table 3.1. Industrial Electric O\&M Energy-Saving Measures and Potential

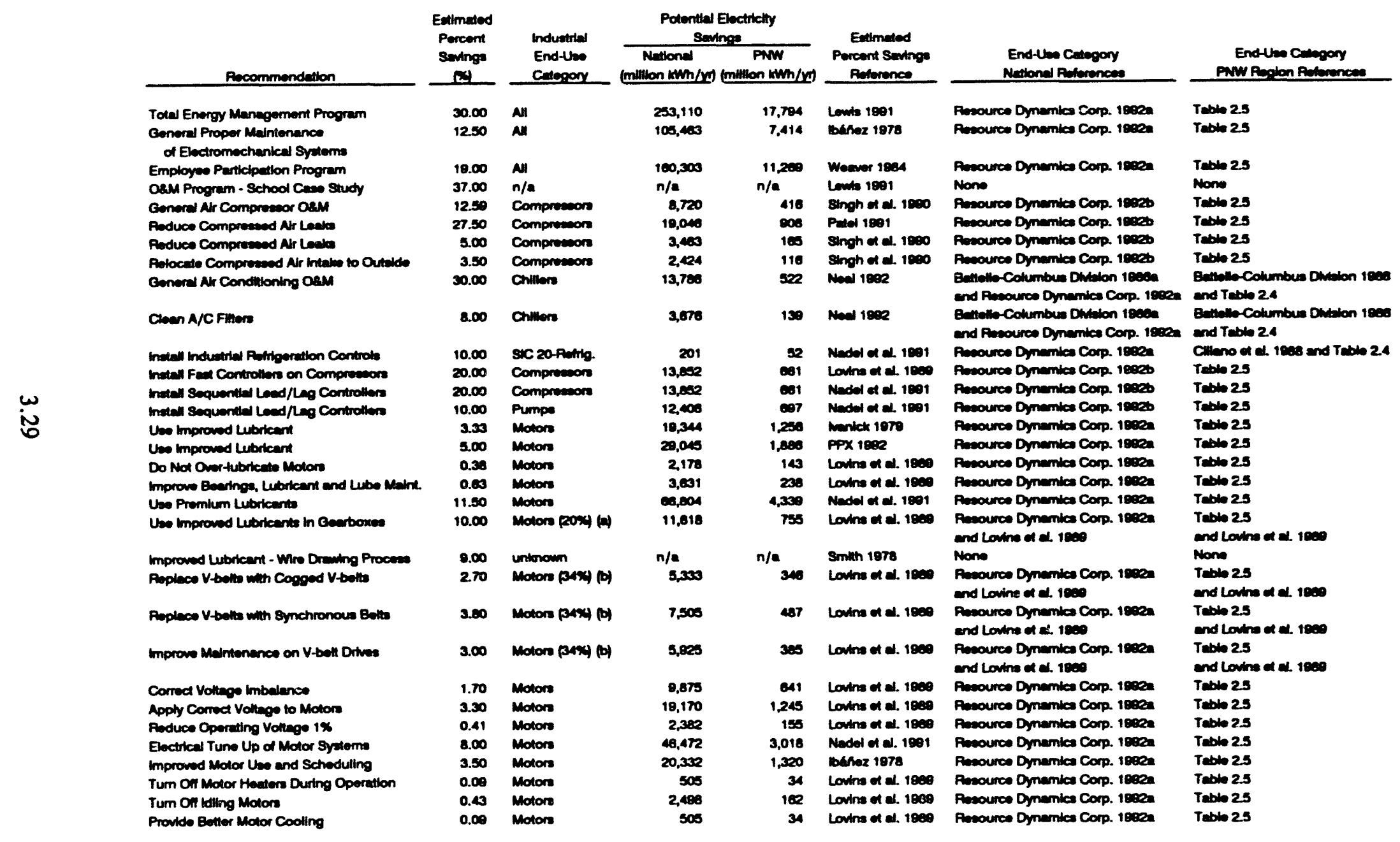

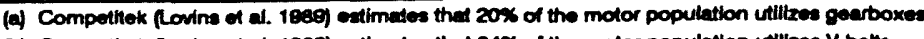

(b) Compettiok (Lovins of al. 180e) extmates that 34X of the motor population utllizes V-betta. 
Table 3.2. Industrial Electric O\&M Measures by DIECO

De-energize excess transformer capacity to avoid utility charges

Reduce load on electric conductors to reduce heat losses

Reduce the pressure of compressed air system to the minimum required

Reduce use of compressed air to minimum/use smaller compressor

Install compressor air intake in coolest location

Eliminate leaks in lines and valves carrying compressed air or other gases

3232

Remove or close off unneeded compressed air lines to eliminate leaks

3243

Install, clean or replace compressor air filters regularly

3311

Use minimum water for processes; cooling, washing, etc.

3312 Shut off cooling water when not required

Operate cooling towers at constant outlet temperature to avoid sub-cooling

Eliminate leaks in water lines, valves, storage tanks, and process equip.

Remove or close off unneeded water lines to avoid potential leaks/freezing

Shut down equipment when not in use or setback its temperature

Turn off conveyers when not in use

Install controls to operate equipment only when loaded

Use most efficient equipment at its maximum capacity

4122

Schedule to run equipment with full loads/use batch type drying ovens

Reduce temperature or power requirement of process equipment on standby Minimize operation of equipment required to be kept in standby condition Locate causes of demand charges and reschedule operations to avoid peak

4312 Evaluate energy use in packaging process/change to reduce energy-intensity

5121 Establish equipment maintenance schedule for or make necessary repairs

5122 Improve lubrication practices for motor driven equipment

5123 Adjust or modify vents on process equipment to minimize energy usage 
Table 3.2. (contd)

Avoid cooling process streams which subsequently must be heated, etc.

$5214 \quad$ Reduce flow rate of process fluids (e.g drying air)

5218 Use optimum temperature for hot processes - washing, drying, forming, etc.

5221 Convert from batch to continuous operation

5222 Use small number of high-output units vs. many small inefficient units

$5224 \quad$ Reduce scrap production

5311

Use minimum safe oven ventilation

5331

5333

Use optimum refrigerator thickness insulation for low temperatures

5335

Reduce infiltration to refrigerated areas/isolated hot process equipment

Use highest acceptable temperature for process chilling or cold storage

Modify refrigeration system to enable compressor to operate at low pressure

5338

5339

Eliminate or reduce frost formation on refrigerator evaporators

5341

Minimize the temperature of refrigeration condenser cooling water

5355

Reduce temperature of service or domestic hot water

5511

Use energy-efficient belts and other improved mechanisms

5512

Insulate tanks, vessels, lines, and process equipment

5514

Increase or repair insulation thickness or process tanks, vessels, lines

5521

Cover and seal open tanks

5525

Use minimum necessary ventilation for process purposes

Isolate hot/cold equipment from manufacturing areas to minimize HVAC

6111 Disconnect lighting fixtures, delamp, or use lower output lamps for min. light needed

6112 Reduce lighting where natural light is available/install skylights

6114 Disconnect ballasts

6121

6122 Rewire for light shutoff in little used areas or where daylight present

6125

Install timers or motion sensors on little used lights or initiate schedule

Improve reflectance of walls and ceilings/add fixture reflectors/clean fixt

6126

Reduce exterior lighting to minimum safe levels

6211

Close doors, windows and loading doors in space conditioned areas

6212

Repair or replace broken windows, sashes, doors etc./plug cracks

6213

Seal unnecessary dampers, flues, louvers, and other wall and roof openings 
Table 3.2. (contd)

DIECO

6214

6215

6231

6232

6236

6237

6238

6241

6242

6243

6244

6245

6246

6247

6249

6255

6272

6273

6312

6313

Install weather stripping on loose-fitting windows and doors

Install door seals, plastic strip doors or air curtains at loading docks

Reduce outside air for ventilation except with economizer/recycle HVAC

Reduce ventilation air to minimum safe levels

Clean or replace air filters regularly

Replace high-resistance grills, ducts, etc. with properly sized fittings

Centralize control of exhaust fans to ensure shutdown or establish program

Keep space temperature lower during heating season, higher during cooling

Minimize areas where space is conditioned/isolate cooler areas from warmer

Reduce heating/shut air conditioning manually when building is unoccupied

Install or use timers or thermostats for space conditioning

Separate controls of air handlers from controls of $\mathrm{A} / \mathrm{C}$ and heating

Close outdoor air dampers during warm-up or cool-down periods

Establish HVAC equipment maintenance schedules

Use water sparingly on air conditioning exchanger to improve heat transfer

Install or upgrade insulation on HVAC distribution systems (pipes, ducts, etc.)

Shut steam or hot water lines to space heating units during mild weather

Modify air conditioning system to enable air compressor to operate at lower

Clean or repair air conditioning refrigerant condensers

Use water coolers and vending machines efficiently 
Table 3.3. Number of Surveys in EADC Database

\begin{tabular}{|c|c|c|c|c|c|c|c|c|c|c|c|c|c|c|c|c|c|c|c|c|}
\hline \multirow[b]{2}{*}{ EADC } & \multicolumn{19}{|c|}{ Induatry SiC Number } & \multirow[b]{2}{*}{ Total } \\
\hline & 20 & 22 & 23 & 24 & 25 & 28 & 27 & 28 & 28 & 30 & 31 & 32 & 33 & 34 & 35 & 30 & 37 & 38 & 30 & \\
\hline Coloredo Siate Uniweralty & 45 & 0 & 0 & 5 & 2 & 5 & 20 & 3 & 2 & 10 & 0 & 13 & 4 & 17 & 18 & $\bullet$ & $\mathbf{5}$ & ө & 3 & 170 \\
\hline Georgla Toch & 34 & 85 & 13 & 13 & 4 & - & $\theta$ & 10 & 0 & 30 & 1 & 4 & 11 & 20 & 17 & $\theta$ & 7 & 7 & 3 & 280 \\
\hline Loulsilane Toch & 18 & 3 & 3 & $\mathbf{2 6}$ & 1 & 8 & 1 & 1 & 4 & 10 & 0 & 8 & 17 & 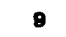 & 8 & 4 & 8 & 1 & 2 & 143 \\
\hline North Carollina ART State Univ. & 11 & 18 & 12 & 8 & 14 & 4 & 3 & 5 & 0 & 10 & 0 & 5 & 7 & 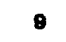 & $\bullet$ & 5 & 4 & 3 & 2 & 120 \\
\hline Oldahome State Unwereity & 33 & 2 & 11 & 2 & 7 & 8 & 15 & $\theta$ & 3 & 23 & o & 10 & 10 & $\infty$ & 12 & 14 & 8 & 10 & 3 & 208 \\
\hline Oregon stete Univerelly & 34 & 1 & 0 & 22 & 0 & 1 & 3 & 2 & 0 & 1 & 0 & 0 & 2 & 1 & 3 & 4 & o & 1 & 0 & 75 \\
\hline Pratio Vew Unworality & 0 & - & 0 & 0 & 0 & 0 & 0 & 0 & 0 & - & 0 & 0 & o & - & 0 & 0 & 0 & 0 & o & - \\
\hline Autgors Universilly & 3 & 0 & 2 & 0 & 2 & 11 & 2 & 7 & 0 & 18 & 0 & 5 & 6 & 10 & 2 & 4 & 1 & 1 & 1 & 75 \\
\hline Srowers indthuse of Teetnology & 4 & 1 & 5 & 1 & 1 & 2 & $\epsilon$ & - & 0 & 8 & 1 & 2 & 0 & 17 & 5 & 7 & 0 & 2 & 3 & $\infty$ \\
\hline Toxas ARM Unmorolly & - & 1 & 0 & 7 & 1 & - & 3 & 5 & 1 & - & 0 & 0 & 3 & 14 & 12 & 1 & $\mathbf{3}$ & 2 & 1 & 75 \\
\hline Tr-Stato Univerally & 2 & 0 & 0 & - & 1 & 0 & 1 & 1 & o & 7 & 0 & 0 & 2 & - & 1 & 2 & o & 0 & o & 28 \\
\hline Univerally of Dayton & 20 & 3 & - & e & 8 & 15 & 14 & 18 & 1 & 20 & 2 & 7 & 17 & 40 & 82 & 10 & 11 & 4 & $\mathbf{s}$ & 204 \\
\hline Untworatity of Kareses & 30 & 0 & 15 & 8 & 7 & 27 & $x$ & 17 & 2 & 23 & 2 & • & - & 24 & $\mathbf{3 0}$ & 20 & 13 & - & 2 & 201 \\
\hline 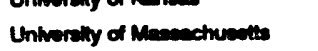 & 11 & ? & 0 & 2 & 0 & 10 & 2 & 8 & 0 & 20 & 0 & 4 & 20 & $\mathbf{z}$ & 13 & 14 & 3 & - & 5 & 170 \\
\hline 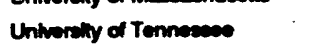 & 37 & 17 & 20 & 8 & 12 & 15 & 2 & 10 & 4 & 20 & 5 & 14 & 13 & 20 & 21 & 24 & 14 & $\bullet$ & - & 200 \\
\hline Untwonity of Whoconatn & 8 & 1 & 0 & 1 & 3 & s & 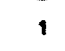 & 3 & 0 & 4 & 2 & 0 & 8 & 14 & 15 & s & 3 & - & 2 & 75 \\
\hline Totel & 308 & 143 & $\infty$ & 100 & $\infty$ & 138 & 114 & 100 & 17 & 230 & 13 & $\mathbf{8}$ & 147 & 307 & 240 & 141 & $\boldsymbol{\infty}$ & $\infty$ & 41 & 2,442 \\
\hline
\end{tabular}


Table 3.4. Number of Recommendations in EADC Database

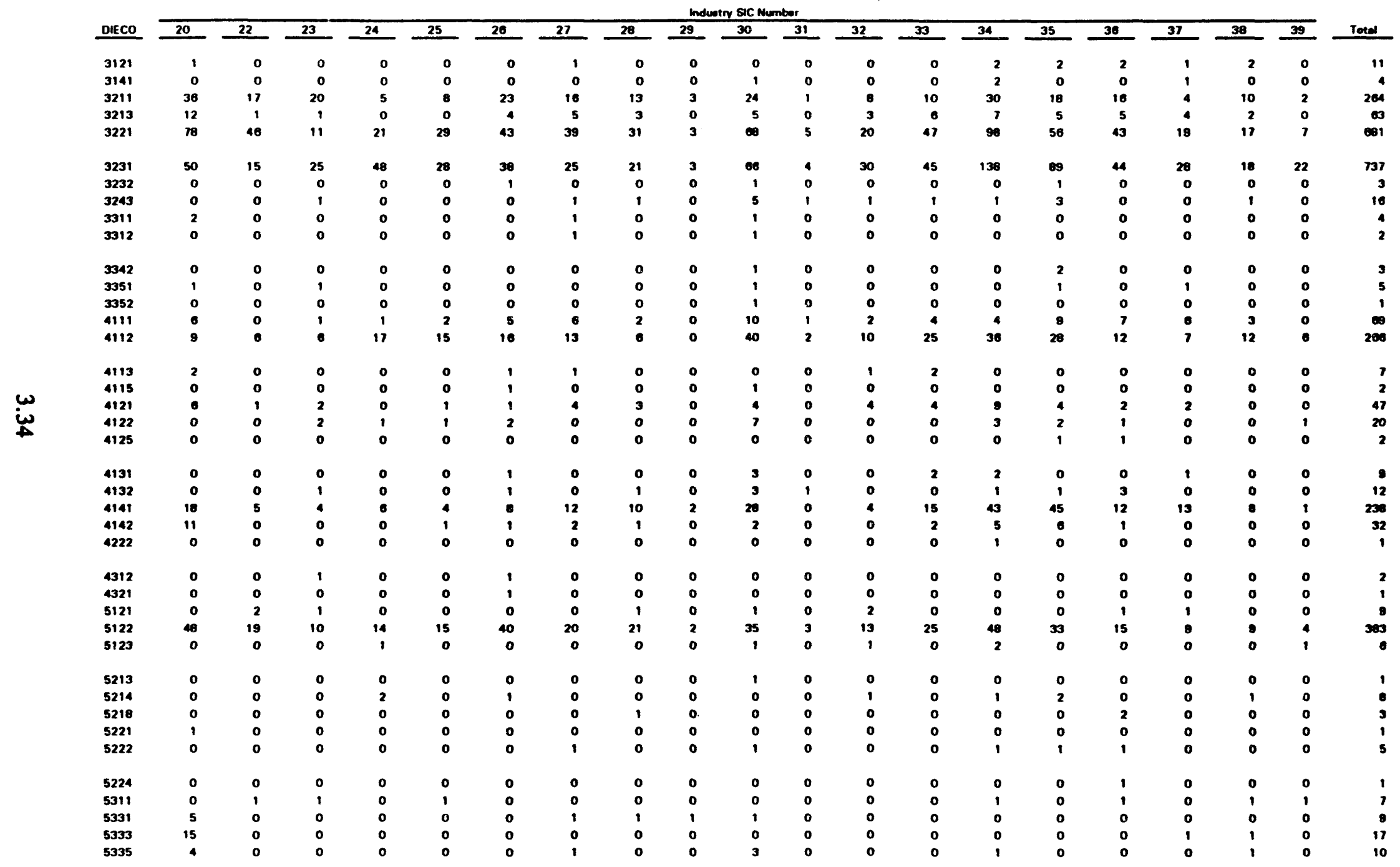


Table 3.4. (contd)

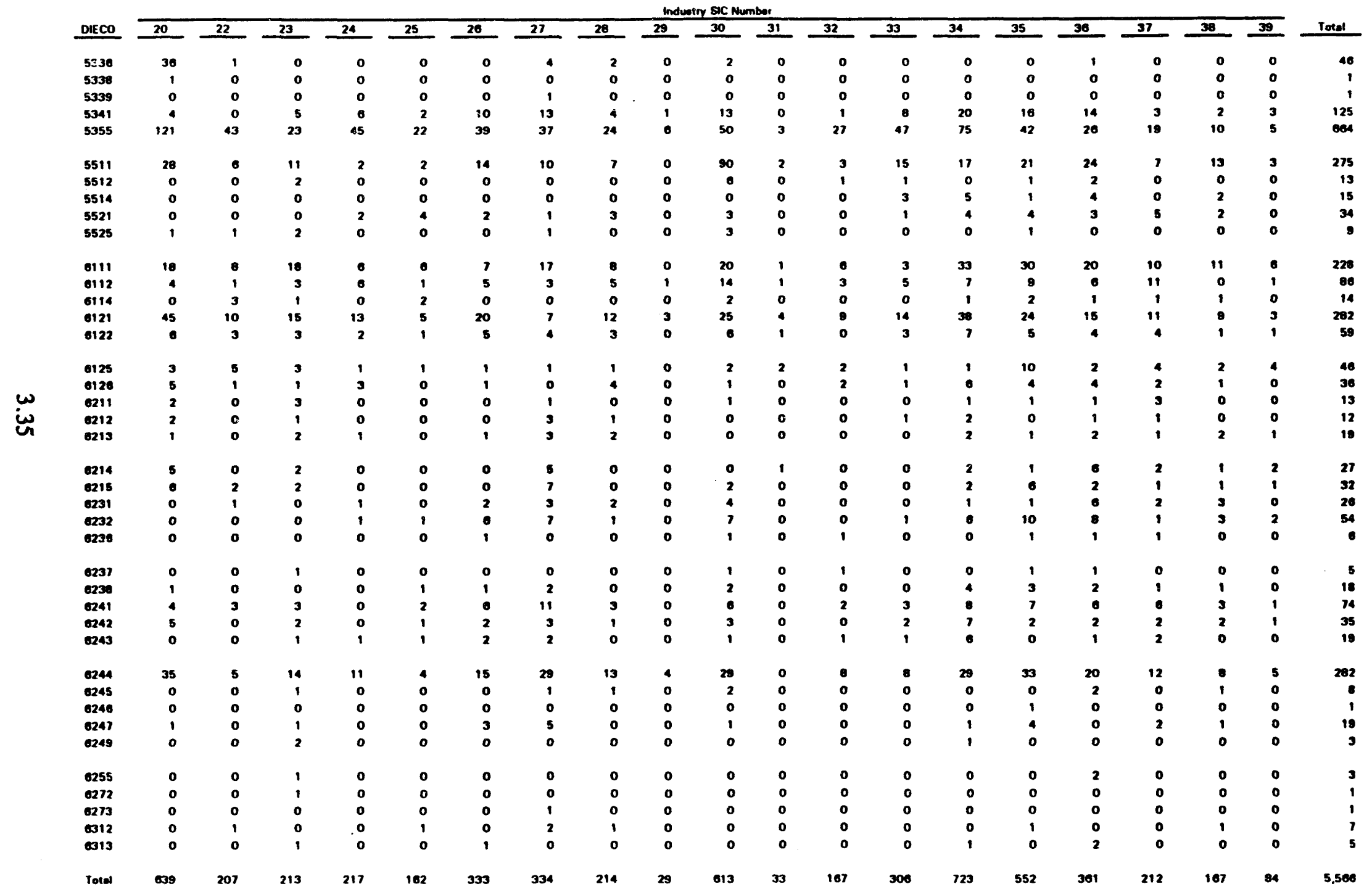


Table 3.5. Frequency of Recommendations in EADC Database (\%)

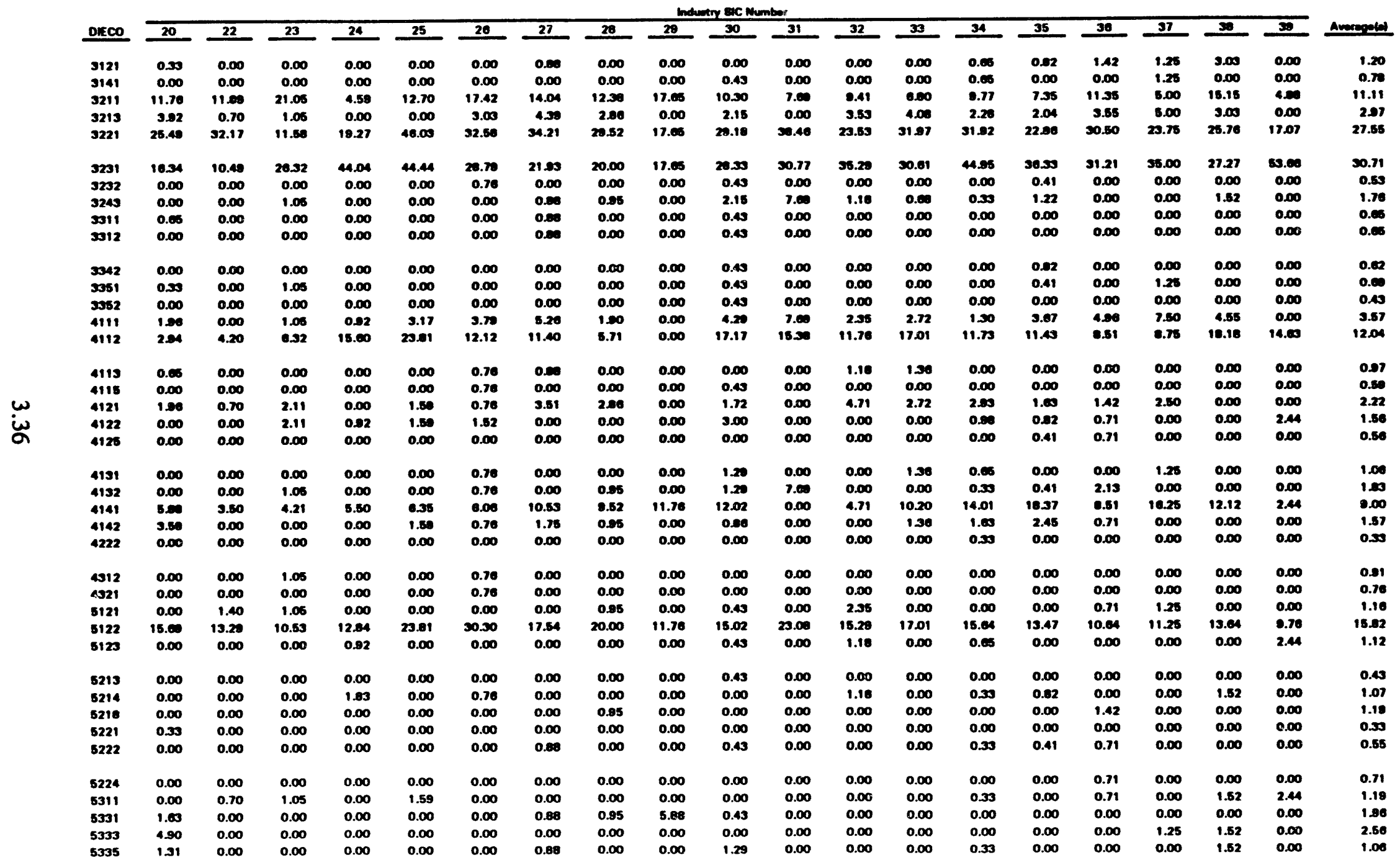


Table 3.5. (contd)

\begin{tabular}{|c|c|c|c|c|c|c|c|c|c|c|c|c|c|c|c|c|c|c|c|c|}
\hline \multirow[b]{2}{*}{ DIECO } & \multicolumn{19}{|c|}{ SIC Number } & \multirow[b]{2}{*}{ Averepolas) } \\
\hline & 20 & 22 & 23 & 24 & 25 & 28 & 27 & 28 & 29 & 30 & 31 & 32 & 33 & 34 & 35 & 36 & 37 & 38 & 39 & \\
\hline 5336 & 11.76 & 0.70 & 0.00 & 0.00 & 0.00 & 0.00 & 3.51 & 1.90 & 0.00 & 0.86 & 0.00 & 0.00 & 0.00 & 0.00 & 0.00 & 0.78 & 0.00 & 0.00 & 0.00 & 3.24 \\
\hline 5338 & 0.33 & 0.00 & 0.00 & 0.00 & 0.00 & 0.00 & 0.00 & 0.00 & 0.00 & 0.00 & 0.00 & 0.00 & 0.00 & 0.00 & 0.00 & 0.00 & 0.00 & 0.00 & 0.00 & 0.33 \\
\hline 5339 & 0.00 & 0.00 & 0.00 & 0.00 & $0 . \infty$ & 0.00 & 0.88 & 0.00 & 0.00 & 0.00 & 0.00 & 0.00 & 0.00 & 0.00 & 0.00 & 0.00 & 0.00 & 0.00 & 0.00 & 0.88 \\
\hline 5341 & 1.31 & 0.00 & 5.26 & 5.50 & 3.17 & 7.58 & 11.40 & 3.81 & 5.88 & 5.58 & 0.00 & 1.18 & 5.44 & 6.51 & 6.53 & 9.93 & 3.75 & 3.03 & 7.32 & 5.18 \\
\hline 5355 & 39.54 & 30.07 & 24.21 & 41.28 & 34.92 & 29.55 & 32.48 & $22.8 \theta$ & 35.29 & 21.46 & 23.08 & 31.76 & 31.97 & 24.43 & 17.14 & 18.44 & 23.75 & 15.15 & 12.20 & 28.82 \\
\hline 5511 & 9.15 & 4.20 & 11.58 & 1.83 & 3.17 & 10.61 & 8.77 & 6.87 & 0.00 & 38.03 & 15.38 & 3.53 & 10.20 & 5.54 & 8.57 & 17.02 & 8.75 & 19.70 & 7.32 & 10.59 \\
\hline 5512 & 0.00 & 0.00 & 2.11 & 0.00 & 0.00 & 0.00 & 0.00 & 0.00 & 0.00 & 2.58 & 0.00 & 1.18 & 0.68 & 0.00 & 0.41 & 1.42 & 0.00 & 0.00 & 0.00 & 1.39 \\
\hline 5514 & 0.00 & 0.00 & 0.00 & 0.00 & 0.00 & 0.00 & 0.00 & 0.00 & 0.00 & 0.00 & 0.00 & 0.00 & 2.04 & 1.00 & 0.41 & 2.84 & 0.00 & 3.03 & 0.00 & 1.99 \\
\hline 5521 & 0.00 & 0.00 & 0.00 & 1.83 & 6.35 & 1.52 & 0.88 & 2.80 & 0.00 & 1.29 & 0.00 & 0.00 & 0.68 & 1.30 & 1.63 & 2.13 & 0.25 & 3.03 & 0.00 & 2.48 \\
\hline 5525 & 0.33 & 0.70 & 2.11 & 0.00 & 0.00 & 0.00 & 0.88 & 0.00 & 0.00 & 1.29 & 0.00 & $0 . \omega 0$ & 0.00 & 0.00 & 0.41 & 0.00 & 0.00 & 0.00 & 0.00 & 0.95 \\
\hline 6111 & 5.88 & 5.59 & 18.95 & 5.50 & 9.52 & 5.30 & 14.91 & 7.62 & 0.00 & 0.58 & 7.69 & 1.08 & 2.04 & 10.75 & 12.24 & 14.18 & 12.50 & 18.67 & 14.83 & 9.98 \\
\hline 6112 & 1.31 & 0.70 & 3.10 & 5.50 & 1.59 & 3.79 & 2.00 & 4.78 & 5.88 & c.ot & 7.09 & 3.53 & 3.40 & 2.28 & 3.67 & 4.28 & 13.75 & 0.00 & 2.44 & 4.24 \\
\hline 6114 & 0.00 & 2.10 & 1.05 & 0.00 & 3.11 & 0.00 & 0.00 & 0.00 & 0.00 & 0.86 & 0.00 & 0.00 & 0.00 & 0.33 & 0.82 & 0.71 & 1.25 & 1.52 & 0.00 & 1.31 \\
\hline 0121 & 14.71 & 0.99 & 15.79 & 11.93 & 7.84 & 15.15 & 0.14 & 11.43 & 17.05 & 10.73 & 30.77 & 10.59 & 9.52 & 12.38 & 9.80 & 10.84 & 13.75 & 13.84 & 7.32 & 12.47 \\
\hline 0122 & 1.90 & 2.10 & 3.10 & 1.83 & 1.59 & 3.79 & 3.51 & 2.86 & 0.00 & 2.58 & 7.69 & 0.00 & 2.04 & 2.28 & 2.04 & 2.84 & 5.00 & 1.52 & 2.44 & 2.89 \\
\hline 6125 & 0.90 & 3.50 & 3.10 & 0.92 & 1.59 & 0.70 & 0.88 & 0.95 & 0.00 & 0.86 & 15.38 & 2.35 & 0.08 & 0.33 & 4.00 & 1.42 & 5.00 & 3.03 & 9.70 & 3.09 \\
\hline 8120 & 1.00 & 0.70 & 1.05 & 2.75 & 0.00 & 0.70 & 0.00 & 3.81 & 0.00 & 0.43 & 0.00 & 2.35 & 0.68 & 1.95 & 1.00 & 2.84 & 2.50 & 1.52 & 0.00 & 1.70 \\
\hline (211 & 0.05 & 0.00 & 3.10 & 0.00 & 0.00 & 0.00 & 0.80 & 0.00 & 0.00 & 0.43 & 0.00 & 0.00 & 0.00 & 0.33 & 0.41 & 0.71 & 3.75 & 0.00 & 0.00 & 1.29 \\
\hline 0212 & 0.05 & 0.00 & 1.05 & 0.00 & 0.00 & 0.00 & 2.03 & 0.95 & 0.00 & 0.00 & 0.00 & 0.00 & 0.08 & 0.65 & 0.00 & 0.71 & 1.25 & 0.00 & 0.00 & 1.07 \\
\hline 0213 & 0.33 & 0.00 & 2.11 & 0.92 & 0.00 & 0.70 & 2.03 & 1.80 & 0.00 & 0.00 & 0.00 & 0.00 & 0.00 & 0.65 & 0.41 & 1.42 & 1.25 & 3.00 & 2.44 & 1.49 \\
\hline 0214 & 1.00 & 0.00 & 2.11 & 0.00 & 0.00 & 0.00 & 4.39 & 0.00 & 0.00 & 0.00 & 1.00 & 0.00 & 0.00 & 0.05 & 0.41 & 4.26 & 2.50 & 1.52 & 4.88 & 2.73 \\
\hline 0215 & 1.80 & 1.40 & 2.11 & 0.00 & 0.00 & 0.00 & 6.14 & 0.00 & 0.00 & 0.80 & 0.00 & 0.00 & 0.00 & 0.65 & 2.45 & 1.42 & 1.25 & 1.52 & 2.44 & 2.02 \\
\hline 8231 & 0.00 & 0.70 & 0.00 & 0.92 & 0.00 & 1.52 & 2.00 & 1.80 & 0.00 & 1.72 & 0.00 & 0.00 & 0.00 & 0.33 & 0.41 & 4.20 & 2.50 & 4.55 & 0.00 & 1.95 \\
\hline 6232 & 0.00 & 0.00 & 0.00 & 0.82 & 1.59 & 4.55 & 0.14 & 0.95 & 0.00 & 3.00 & 0.00 & 0.00 & 0.08 & 1.95 & 4.08 & 5.67 & 1.25 & 4.55 & 4.88 & 3.09 \\
\hline 6230 & 0.00 & 0.00 & 0.00 & 0.00 & 0.00 & 0.78 & 0.00 & 0.00 & 0.00 & 0.43 & 0.00 & 1.16 & 0.00 & 0.00 & 0.41 & 0.71 & 1.25 & 0.00 & 0.00 & 0.79 \\
\hline 8237 & 0.00 & 0.00 & 1.05 & 0.00 & 0.00 & 0.00 & 0.00 & 0.00 & 0.00 & 0.43 & 0.00 & 1.18 & 0.00 & 0.00 & 0.41 & 0.71 & 0.00 & 0.00 & 0.00 & 0.76 \\
\hline 0230 & 0.33 & 0.00 & 0.00 & 0.00 & 1.59 & 0.70 & 1.75 & 0.00 & 0.00 & 0.86 & 0.00 & 0.00 & 0.00 & 1.30 & 1.22 & 1.42 & 1.25 & 1.52 & 0.00 & 1.20 \\
\hline 0241 & 1.31 & 2.10 & 3.18 & 0.00 & 3.17 & 4.55 & 9.05 & 2.86 & 0.00 & 2.58 & 0.00 & 2.35 & 2.04 & 2.61 & 2.86 & 4.20 & 7.50 & 4.55 & 2.44 & 3.62 \\
\hline 0242 & 1.00 & 0.00 & 2.11 & 0.00 & 1.59 & 1.52 & 2.00 & 0.85 & 0.00 & 1.29 & 0.00 & 0.00 & 1.30 & 2.28 & 0.82 & 1.42 & 2.50 & 3.03 & 2.44 & 1.83 \\
\hline 6243 & 0.00 & 0.00 & 1.05 & 0.92 & 1.59 & 1.52 & 1.75 & 0.00 & 0.00 & 0.43 & 0.00 & 1.18 & 0.08 & 1.95 & 0.00 & 0.71 & 2.50 & 0.00 & 0.00 & 1.30 \\
\hline 0244 & 11.44 & 3.50 & 14.74 & 10.09 & 0.35 & 11.36 & 25.44 & 12.38 & 23.53 & 12.45 & 0.00 & 9.41 & 5.44 & 9.45 & 13.47 & 14.18 & 15.00 & 12.12 & 12.20 & 12.36 \\
\hline 0245 & 0.00 & 0.00 & 1.05 & 0.00 & 0.00 & 0.00 & 0.88 & 0.95 & 0.00 & 0.80 & 0.00 & 0.00 & 0.00 & 0.00 & 0.00 & 1.42 & 0.00 & 1.52 & 0.00 & 1.11 \\
\hline 0240 & 0.00 & 0.00 & 0.00 & 0.00 & 0.00 & 0.00 & 0.00 & 0.00 & 0.00 & 0.00 & 0.00 & 0.00 & 0.00 & 0.00 & 0.41 & 0.00 & 0.00 & 0.00 & 0.00 & 0.41 \\
\hline 0247 & 0.33 & 0.00 & 1.05 & 0.00 & 0.00 & 2.27 & 4.39 & 0.00 & 0.00 & 0.43 & 0.00 & 0.00 & 0.00 & 0.33 & 1.03 & 0.00 & 2.50 & 1.52 & 0.00 & 1.00 \\
\hline 6249 & 0.00 & 0.00 & 2.11 & 0.00 & 0.00 & 0.00 & 0.00 & 0.00 & 0.00 & 0.00 & 0.00 & 0.00 & 0.00 & 0.33 & 0.00 & 0.00 & 0.00 & 0.00 & 0.00 & 1.22 \\
\hline 0255 & 0.00 & 0.00 & 1.05 & 0.00 & 0.00 & 0.00 & 0.00 & 0.00 & 0.00 & 0.00 & 0.00 & 0.00 & 0.00 & 0.00 & 0.00 & 1.42 & 0.00 & 0.00 & 0.00 & 1.24 \\
\hline 6272 & 0.00 & 0.00 & 1.05 & 0.00 & 0.00 & 0.00 & 0.00 & 0.00 & 0.00 & 0.00 & 0.00 & 0.00 & 0.00 & 0.00 & 0.00 & 0.00 & 0.00 & 0.00 & 0.00 & 1.05 \\
\hline 0273 & 0.00 & 0.00 & 0.00 & 0.00 & 0.00 & 0.00 & 0.80 & 0.00 & 0.00 & 0.00 & 0.00 & 0.00 & 0.00 & 0.00 & 0.00 & 0.00 & 0.00 & 0.00 & 0.00 & 0.88 \\
\hline$\infty 12$ & 0.00 & 0.70 & 0.00 & 0.00 & 1.59 & 0.00 & 1.75 & 0.95 & 0.00 & 0.00 & 0.00 & 0.00 & 0.00 & 0.00 & 0.41 & 0.00 & 0.00 & 1.52 & 0.00 & 1.15 \\
\hline 0013 & 0.00 & 0.00 & 1.05 & 0.00 & 0.00 & 0.78 & 0.00 & 0.00 & 0.00 & 0.00 & 0.00 & 0.00 & 0.00 & 0.33 & 0.00 & 1.42 & $0 . \infty 0$ & 0.00 & 0.00 & 0.89 \\
\hline Amercostol & 5.22 & 5.57 & 5.10 & 7.90 & 9.10 & 0.31 & 0.37 & 5.82 & 15.51 & 4.70 & 14.93 & 7.02 & 0.71 & 4.81 & 4.00 & 5.12 & 0.00 & 6.84 & 6.54 & 3.50 \\
\hline
\end{tabular}


Table 3.6. Average Energy Savings Identified in EADC Database (\%)

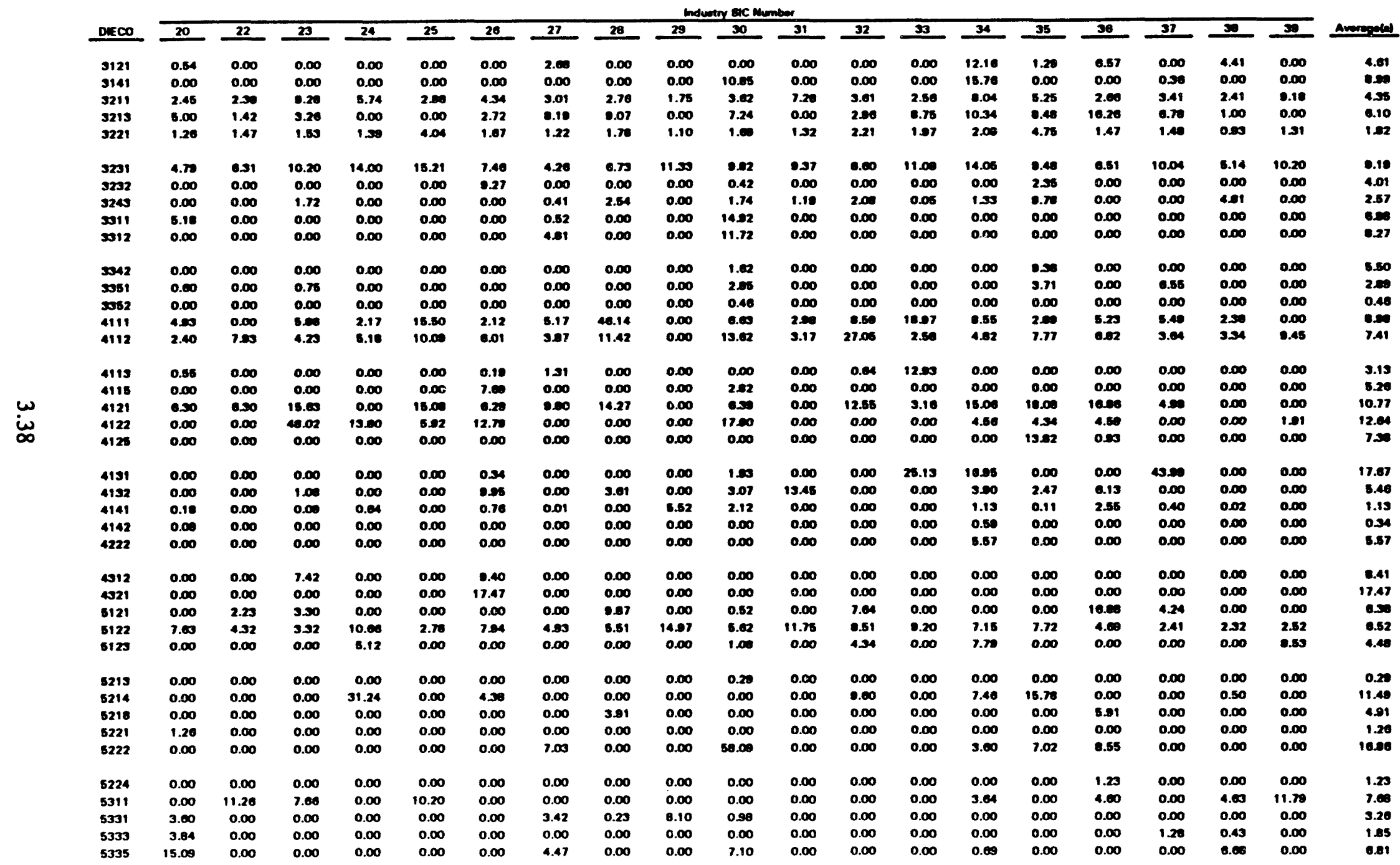


Table 3.6. (contd)

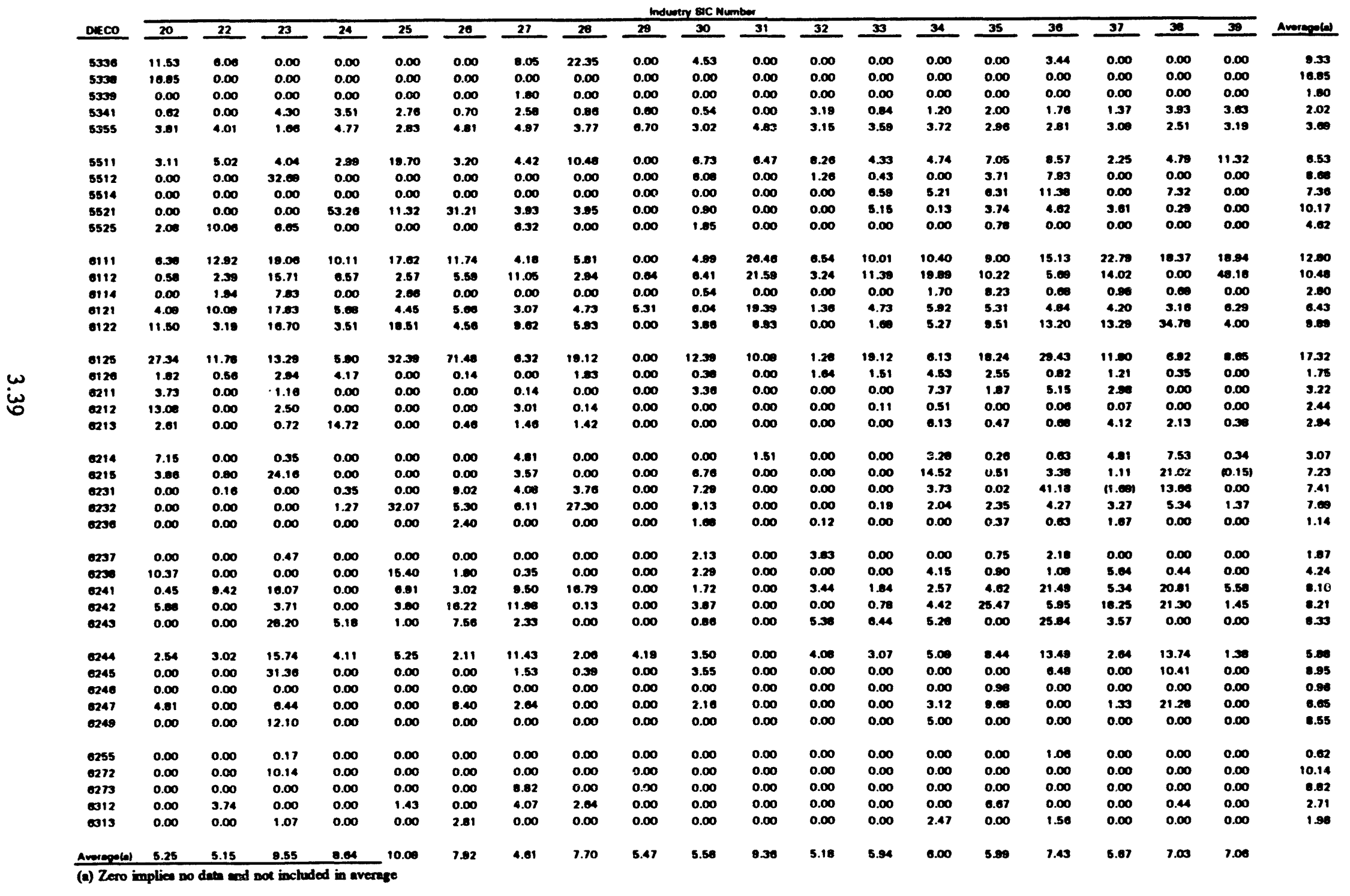


Table 3.7. Summary of Energy-Savings Potential (\%)

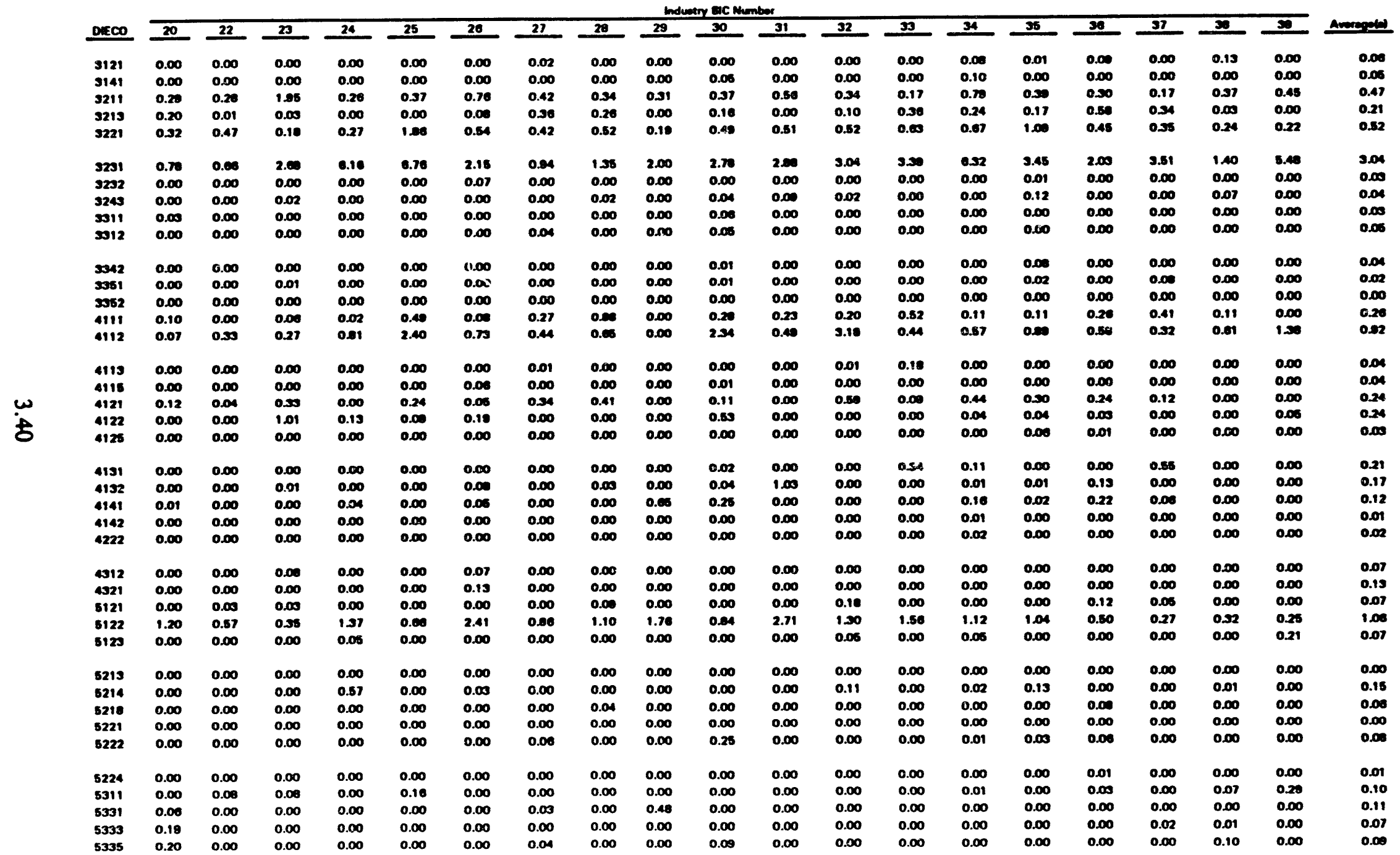


Table 3.7. (contd)

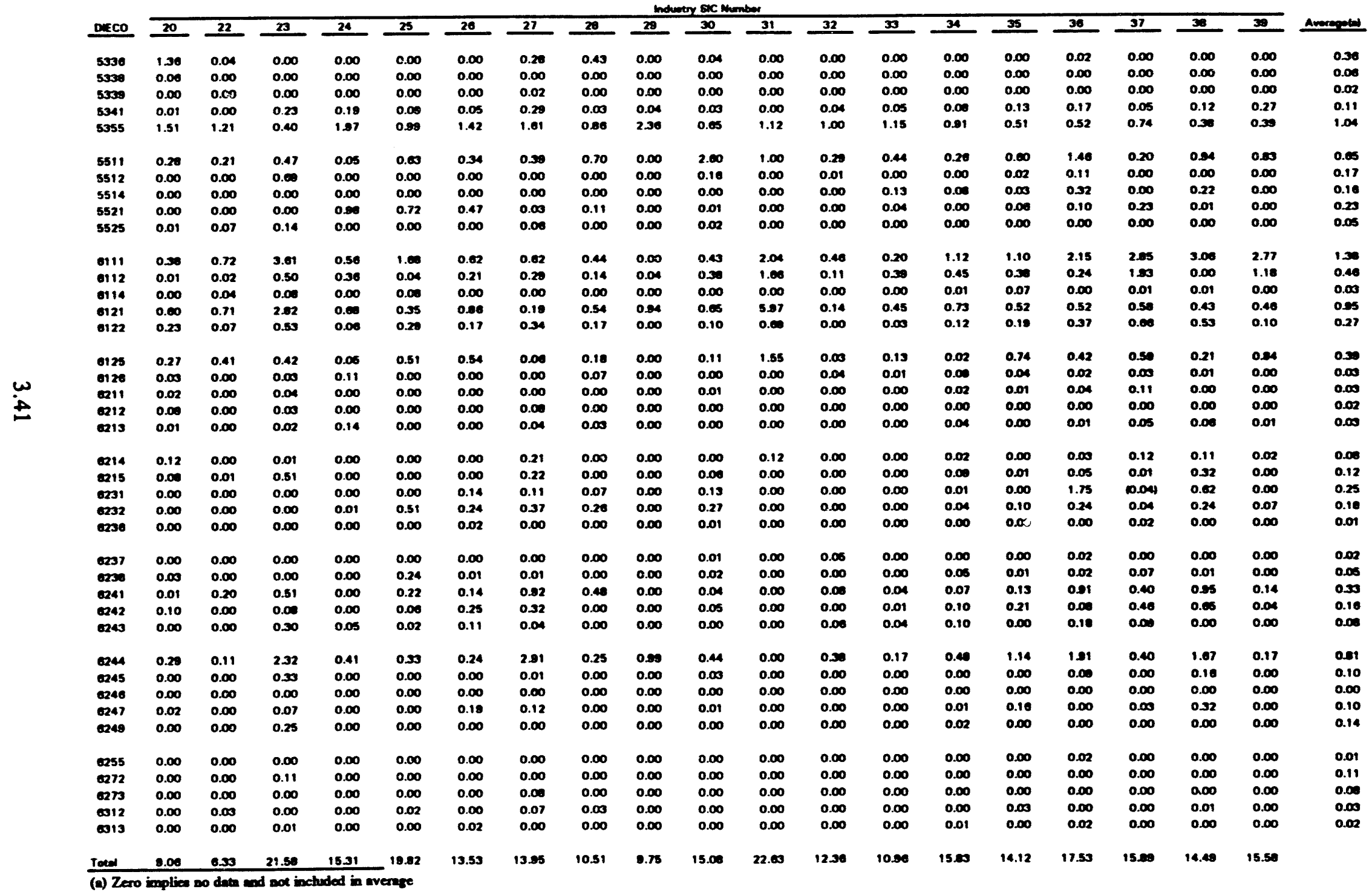


Table 3.8. Average DIECO Implementation Cost (\$/kWh)

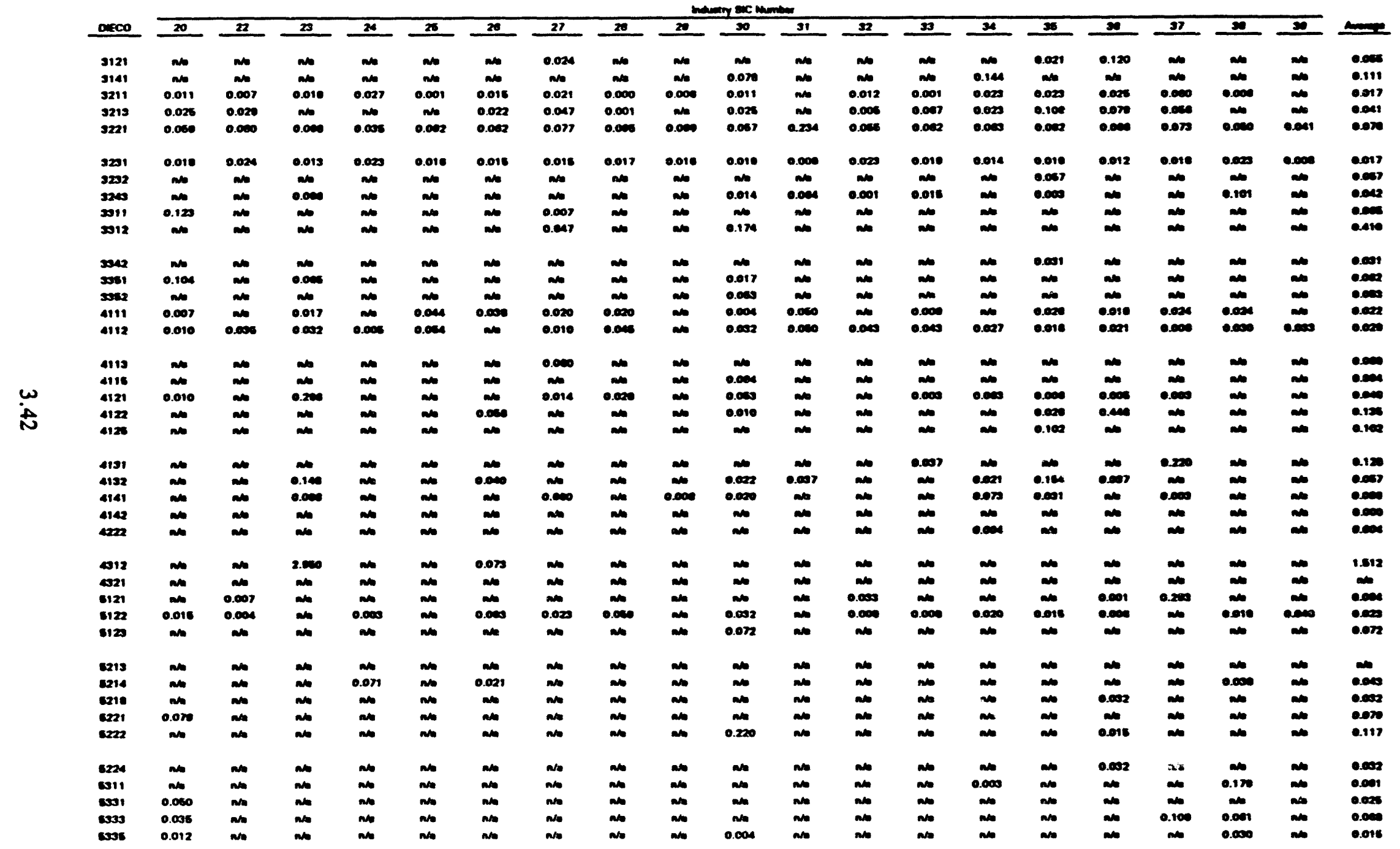


Table 3.8. (contd)

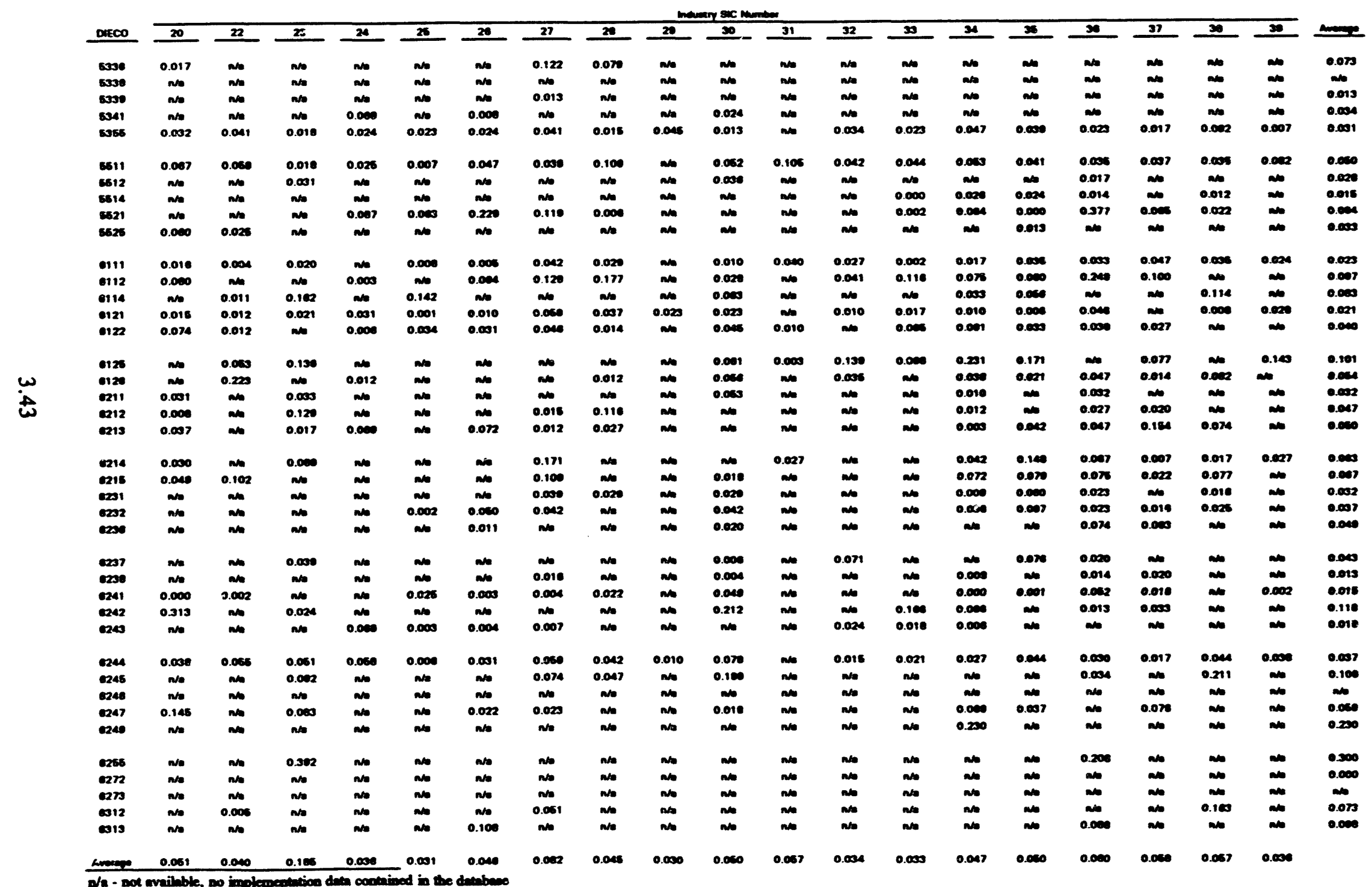


Table 3.9. National Industrial O\&M Energy-Savings Potential (million kWh/yr)

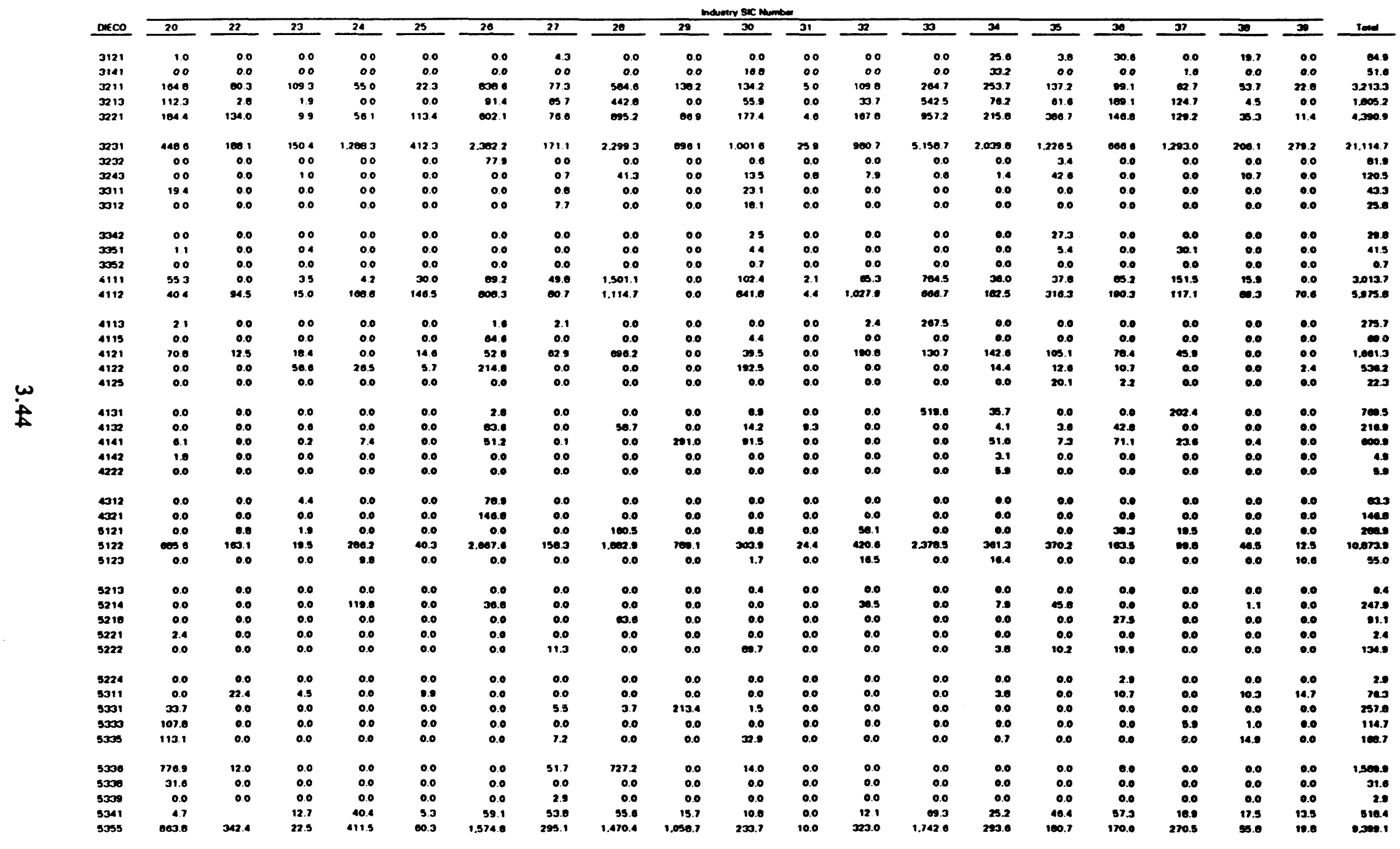




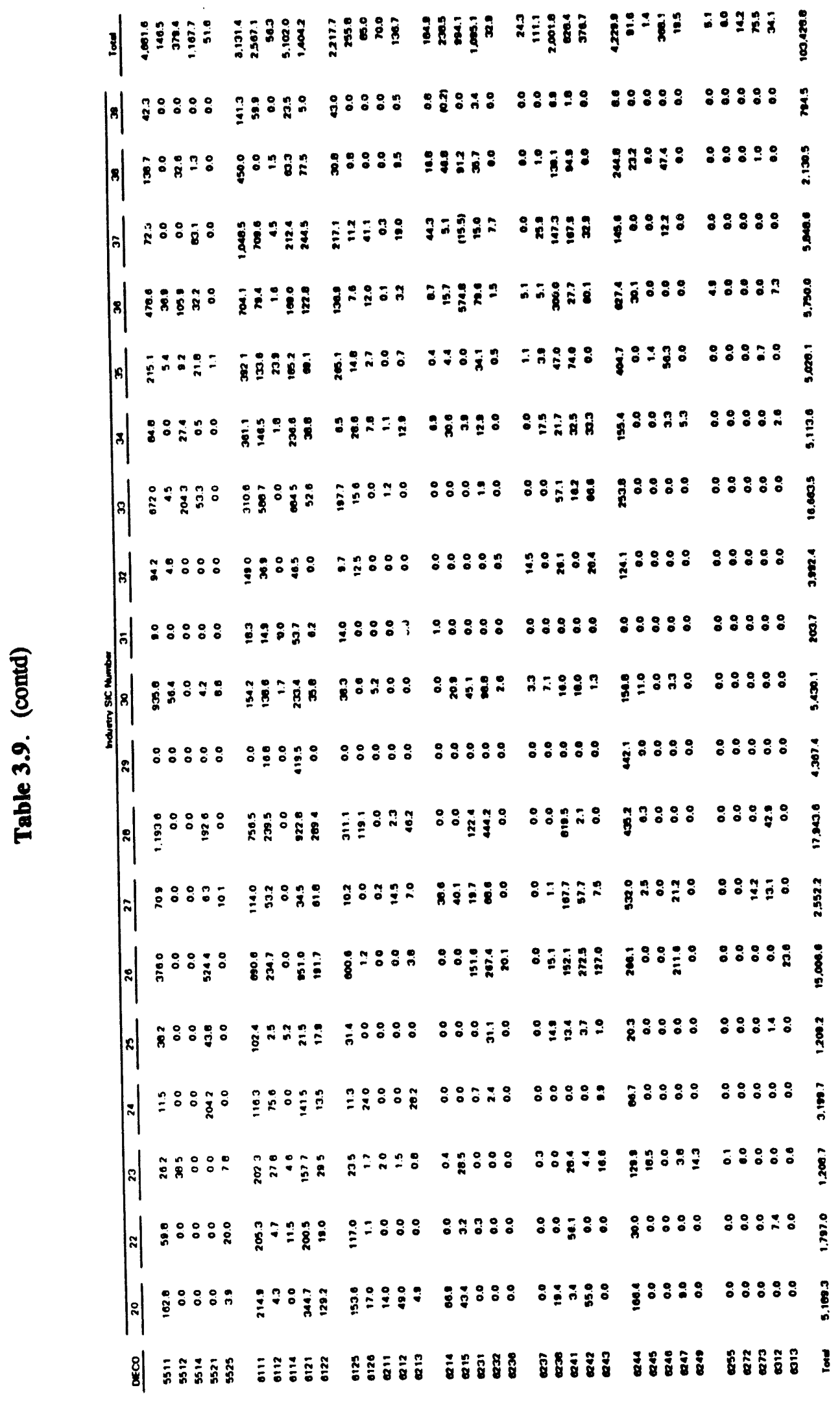


Table 3.10. Pacific Northwest Industrial O\&M Energy-Savings Potential (million $\mathbf{k W h} / \mathrm{yr}$ )

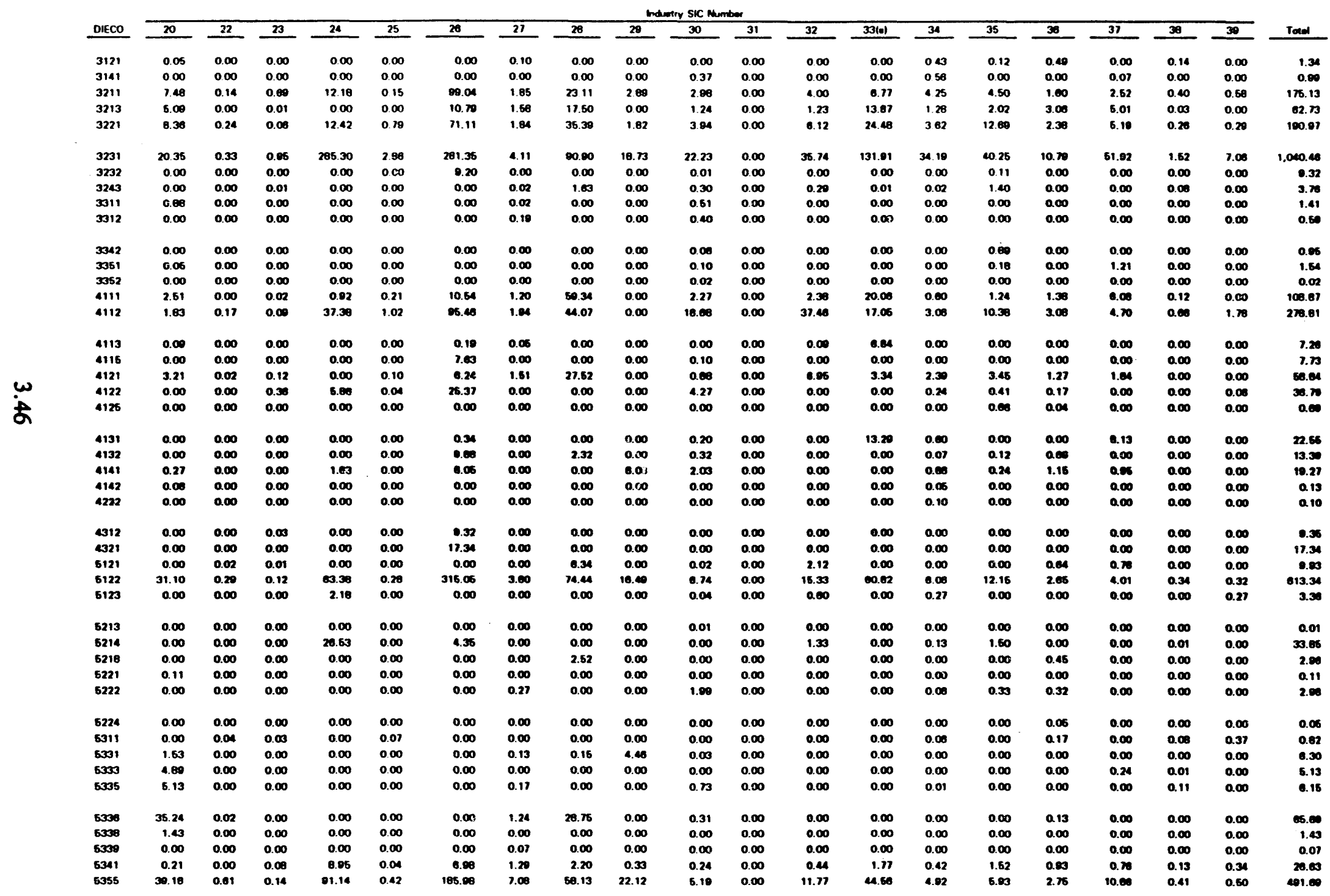


Table 3.10. (contd)

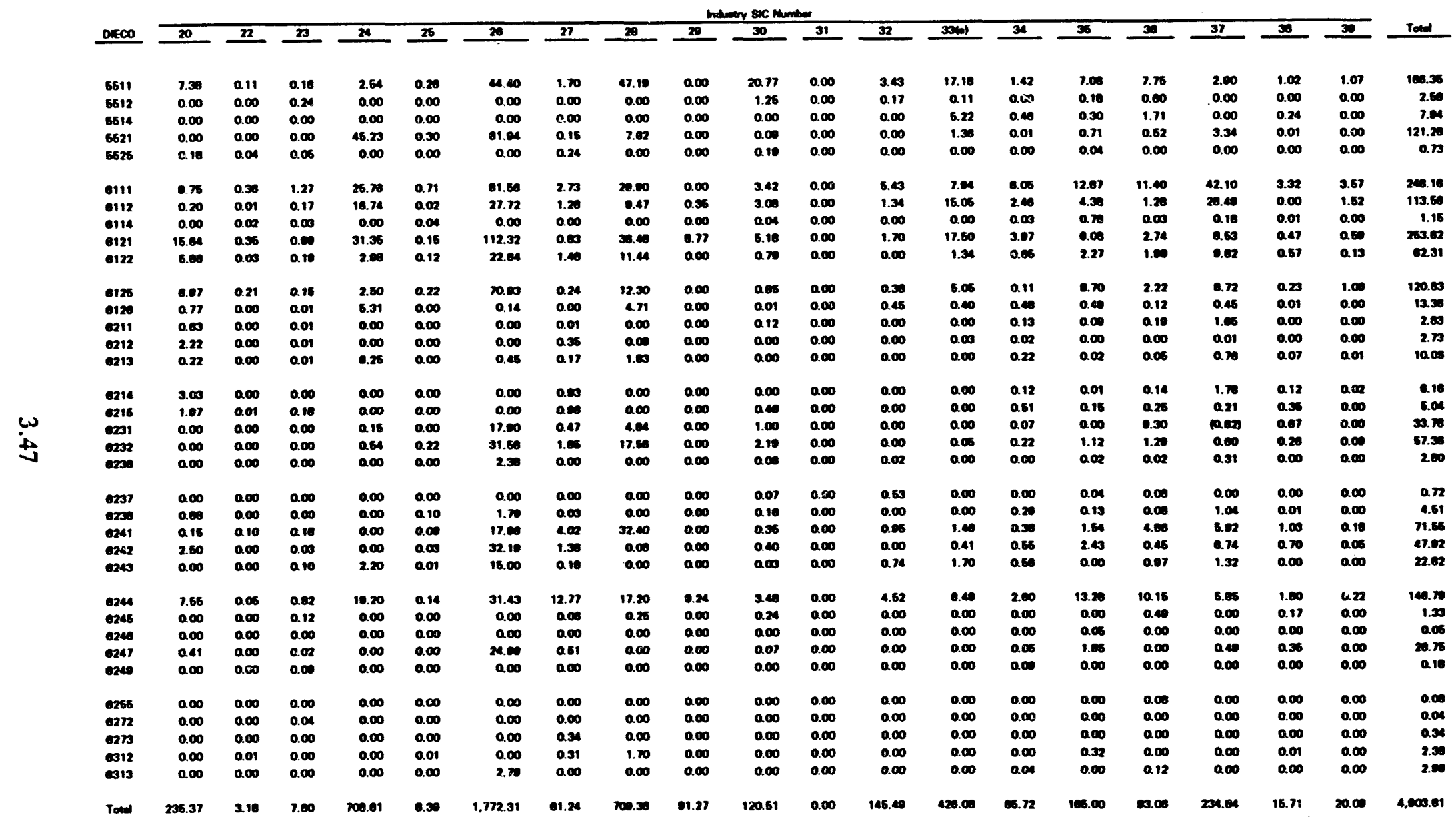

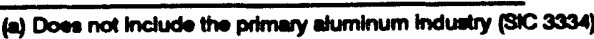


Table 3.11. Pacific Northwest Industrial O\&M Energy-Savings Potential by Equipment End-Use Category

\begin{tabular}{l} 
DIECO \\
\hline \\
\hline 3231 \\
3221 \\
3211 \\
3213 \\
3232 \\
3243 \\
\\
\\
\\
6122 \\
6365 \\
4321 \\
4113 \\
\\
\end{tabular}

DIECO Description

Air Compreseore and Compreseed Air Syeteme:

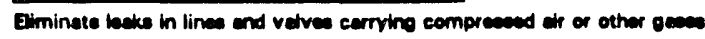

Inerell compreceser sit inteke in coolect locetion

neduce the presene of cempresend if ayerem to the minimum required

Riduce ues of compresead ir to minimumher omeller compreseor

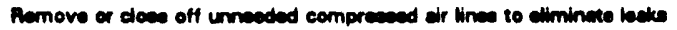

Inatell, claen or replece compreceor et finere regulety

eub-toted

Matore end Motor Drive Sretems

improve kerication precticen for moter ditven equipment

une eneroy-efficient belte and other improved mochenieme

Uporede or repair and maine ein converere

Tum off comverere when not in ues

abroted

Lohting:

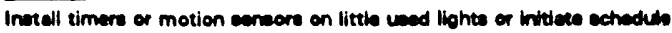

Dieconnect lighting fixtures, delemp, or un lower artout lempe for min. Woth needed

Improve reflectence of wathe and coilinge/edd fixture reflectora/cheen fixt

Reduce lighting where notured light is evelldblefinatell akytiohe

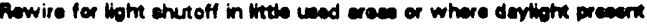

Aaduce exterior lighting to minimum aefe lovele

Dieconnect belleats

Overlep curtediel work houre with normel doy hours

abroted

HVAC Syetema:

Install of wo timere or thermoctots for epace conditioning

Keep epece temperature lower during heeting ween, hisher during coeling

Reduce ventiletion air to minimum eafe bevels

Minimize ereen whare epeces is conditionadisolote cooler erees from wermer

Reduce ovtaide dif for ventiletion except with economizer/recyede HVAC

Exteblish HVAC equipmen maimenence schedules

Reduce heating/aturt air condtioning menuelly when bulling in unoceapied

Sed unnocemery dempere, them, lowvere, and other well and reof copeninge

Instell weether stripping on locen-fitting windowe end docese

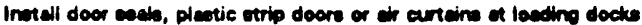

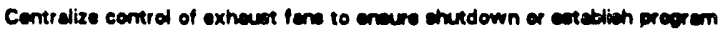

Cloee doore, windowe and laedino doore in epece cendidiened ereen

Cleen or repleces air filtere reaulerty

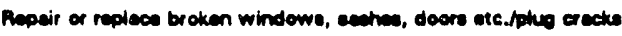

Cleen of repair eir conditioning refrioer ent condenwere

seperate controle of air hendtere from controle of AC and heating

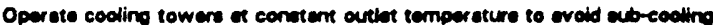

bolate hot/cold equipment from merutecturing erees to minimize HVAC

Peplece high-reeietence grille, ducts, otc. whth property wined fittines

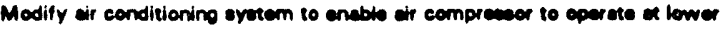

Ues woter eperinaly on eir conditioning exchenoer to improve hem trenofer

Close oundoor air dempere during werm-up of coot-down pariode

Shut steern of hot water line to epece haeting units during mild weether ubroted

\begin{tabular}{|c|c|c|c|}
\hline $\begin{array}{c}\text { PNW } \\
\text { Potentid } \\
\text { (million kWhyr) }\end{array}$ & $\begin{array}{c}\text { DIECO } \\
\text { Frequency } \\
\text { (x) }\end{array}$ & $\begin{array}{c}\text { Avereos } \\
\text { Sovinee } \\
\text { (\% of Plent) }\end{array}$ & $\begin{array}{c}\text { Impl. } \\
\text { Coot } \\
(\$ \mathrm{kWh})\end{array}$ \\
\hline $1,040.46$ & 30.71 & 0.10 & 0.0108 \\
\hline 100.07 & 27.65 & 1.82 & 0.0770 \\
\hline 175.13 & 11.11 & 4.36 & 0.0170 \\
\hline 02.73 & 2.07 & 6.10 & 0.0407 \\
\hline 0.32 & 0.63 & 4.01 & 0.0570 \\
\hline 3.70 & 1.78 & 2.57 & 0.0420 \\
\hline \multicolumn{4}{|l|}{$1,482.37$} \\
\hline 013.34 & 16.82 & 6.62 & 0.0230 \\
\hline 401.60 & 20.82 & 3.60 & 0.0337 \\
\hline 17.34 & 0.70 & 17.47 & ne \\
\hline 7.26 & 0.07 & 3.13 & 0.0688 \\
\hline
\end{tabular}

$1,120.03$

\begin{tabular}{rrrr}
253.02 & 12.47 & 0.43 & 0.0209 \\
248.16 & 0.08 & 12.80 & 0.0233 \\
120.83 & 3.00 & 17.32 & 0.1011 \\
113.68 & 4.24 & 10.48 & 0.0976 \\
62.31 & 2.89 & 0.89 & 0.0396 \\
13.30 & 1.78 & 1.76 & 0.0640 \\
1.18 & 1.31 & 2.80 & 0.0830 \\
0.10 & 0.33 & 6.67 & 0.0030 \\
\hline
\end{tabular}

813.00

\begin{tabular}{|c|c|c|c|}
\hline 146.78 & 12.38 & 6.88 & 0.0388 \\
\hline 71.65 & 3.62 & 8.10 & 0.0147 \\
\hline 67.30 & 3.00 & 7.60 & 0.0372 \\
\hline 47.02 & 1.83 & 8.21 & 0.1180 \\
\hline 33.78 & 1.05 & 7.41 & 0.0322 \\
\hline 28.76 & 1.60 & 6.65 & 0.0601 \\
\hline 22.82 & 1.30 & 8.33 & 0.0187 \\
\hline 10.00 & 1.40 & 2.94 & 0.0603 \\
\hline 6.10 & 2.73 & 3.07 & 0.0826 \\
\hline 6.04 & 2.02 & 7.23 & 0.0680 \\
\hline 4.18 & 1.20 & 4.24 & 0.0128 \\
\hline 2.03 & 1.20 & 3.22 & 0.0320 \\
\hline 2.80 & 0.78 & 1.14 & 0.0496 \\
\hline 2.73 & 1.07 & 2.44 & 0.0467 \\
\hline 2.30 & 1.16 & 2.71 & 0.0731 \\
\hline 1.33 & 1.11 & 8.06 & 0.1085 \\
\hline 0.06 & 0.82 & 6.60 & 0.0314 \\
\hline 0.73 & 0.05 & 4.62 & 0.0329 \\
\hline 0.72 & 0.78 & 1.87 & 0.0426 \\
\hline 0.34 & 0.08 & 8.82 & No \\
\hline 0.18 & 1.22 & 8.66 & 0.2304 \\
\hline 0.06 & 0.41 & 0.88 & ne \\
\hline 0.04 & 9.05 & 10.14 & 0.0000 \\
\hline
\end{tabular}


Table 3.11. (contd)

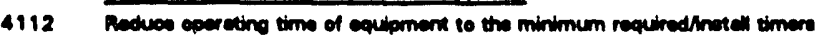

4111 Shux down equipment when not in use or cotbeck ite tempercture

4131 Raduce tumperctere of power requirement of procene capipment en stendby

4132 Minimize operction of caulpmant required to bo kept in etendby conditien

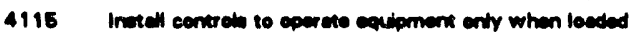

$$
\text { eubretel }
$$

Inculation:

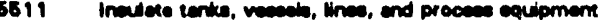

6614 Cower and ecel apen tenike

6331 Une eptimum nofrigereter thicknes modetion for low temperatures

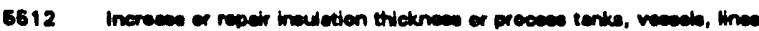

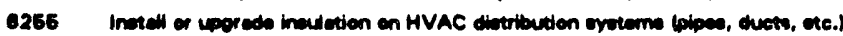
abteted

\begin{tabular}{|c|c|c|c|}
\hline $\begin{array}{c}\text { PNW } \\
\text { Potentid } \\
\text { inillion kwm }\end{array}$ & $\begin{array}{c}\text { DIECO } \\
\text { Frequency } \\
\text { (x) }\end{array}$ & $\begin{array}{l}\text { Avereses } \\
\text { Savines } \\
\text { (\% of Plemt) }\end{array}$ & $\begin{array}{l}\text { Impl. } \\
\text { Coat } \\
\text { (s/nWh) }\end{array}$ \\
\hline 270.01 & 12.04 & 7.41 & 0.0280 \\
\hline 108.07 & 3.67 & $\mathbf{e . 0 8}$ & 0.0218 \\
\hline 22.65 & 1.00 & 17.67 & 0.1284 \\
\hline 13.30 & 1.03 & 5.48 & 0.0674 \\
\hline 7.73 & 0.60 & 6.28 & 0.0937 \\
\hline
\end{tabular}

\begin{tabular}{rrrr}
189.36 & 10.68 & 6.63 & 0.0408 \\
7.04 & 1.00 & 7.36 & 0.0163 \\
0.30 & 1.08 & 3.26 & 0.0248 \\
2.60 & 1.30 & 8.68 & 0.0281 \\
0.08 & 1.24 & 0.02 & 0.3004 \\
\hline
\end{tabular}

Ventilotion Syatems:

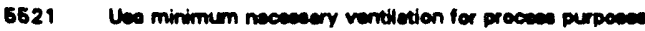

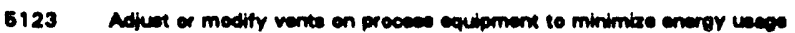
curtet

$\begin{array}{rrrr}121.28 & 2.48 & 10.17 & 0.0041 \\ 3.30 & 1.12 & 4.48 & 0.0710\end{array}$

Refriperetion Syrem:

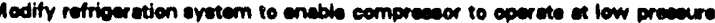
Uee highest eccepteble tempereture for proceen ctilling of cold etor exe

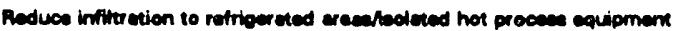
Ellminate or reduce froet formetion on nefriowertor oveporesere Minimize the temperature of refrioeretion condenere cooling water abtoted

\begin{tabular}{rrrc}
65.00 & 3.24 & 0.33 & 0.0725 \\
6.16 & 1.00 & 6.81 & 0.0164 \\
6.13 & 2.56 & 1.86 & 0.0682 \\
1.43 & 0.33 & 16.85 & N/ \\
0.07 & 0.88 & 1.80 & 0.0129 \\
\hline 78.47 & & &
\end{tabular}

Othet Migcalleneoun Oppentunitica:

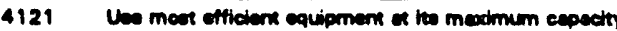

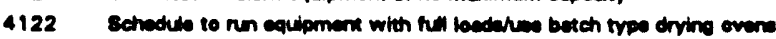

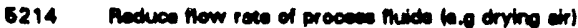

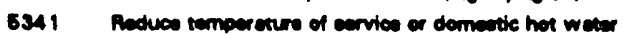

4141 Locete cevere of demend cherese and rescheduls operetions to waid pack

6121 Exteblich equipment maintionenoe schodulo for or make neosesery repelire

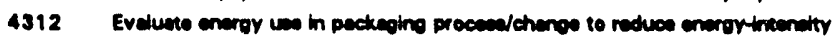

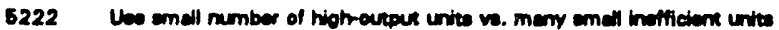

0313 Ua weter coolere and vending mechines efficiently

6218 the optimum temperoture for hot procesene - wenhing, drving, forming, ete.

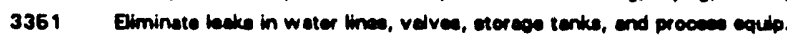

3311 Ues minimum water for procenwe; coeline, wehing, ofe.

3121 De-energize axceen trenstormer cepecity to evoid unittry cherene

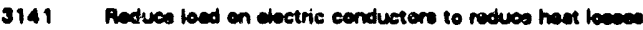

6311 Uen minimum eafe oven vernelletion

4126 Schadub beking timee of cmell and leres cemponente to minimbe eneroy we

3312 Shet of cooline weter when not reapined

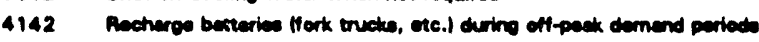

5221 Commen trem becch to continuove operretien

6224 Reduce ecrep production

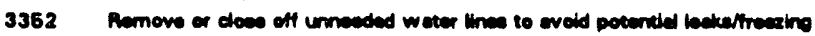

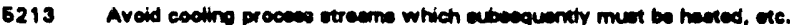

$$
\text { outered }
$$




\subsection{O\&M Impact Analysis in the Pulp and Paper Industry}

The analysis presented in Section 3.0 is based on resources that reviewed the electric energy consumption of all twenty of the industries comprising the manufacturing sector. In order to condense the large amount of energy consumption information associated with all 20 sectors into a presentable size, general categories describing components and processes common to many of the 20 industries were used as a means of presenting the information. While this is an efficient method of comparing component energy consumption between various industries, it does not provide a very accurate portrait of the processes consumption characteristics of a single industry. For the most part the electrical components utilized in the manufacturing industries are the same (motors, pumps, lighting, etc.), however, the environment in which they operate and the processes in which they are used can vary dramatically. Energy management attitudes and concerns also differ between industries. In order to determine whether differences such as these will have a significant affect on the results of the assessment of the resource potential that may be achieved through improvements to O\&M practices, and to determine the accuracy of the previous results, a detailed examination of the energy consumption characteristics, O\&M practices, and potential impacts of improvements to these practices in the pulp and paper industry was conducted. The pulp and paper industry was selected for this study because of its high electric energy consumption and because of the impact it has on the magnitude of the Pacific Northwest's electric energy consumption.

\subsection{Energy Consumption Characteristics}

Before the effect that improvements to O\&M techniques may have on the pulp and paper industry can be assessed, a thorough understanding of where and how the electric energy is consumed is needed. The purpose of this section is to augment the previously presented data with information derived from resources which specifically addresses the pulp and paper industry.

Analysis of energy consumption at the component and process level is complex. No two plants, even if defined by the same four digit SIC, have identical process lines or equipment. Plants employ varying degrees of state-of-the-art technology, some of which can have a profound effect on the energy consumption rates within a plant. Energy use can also vary dramatically from plant to plant depending on the raw materials and processes used, the type and age of the equipment, the capacity utilization, and plant-specific operating practices. It is this diversity in manufacturing operations that makes energy analysis at the process level extremely difficult.

Because a single source which adequately examines process and equipment energy consumption could not be found, energy consumption characteristics of the pulp and paper processes were formed from a large number of references. Table 4.1 presents the process and equipment energy consumption information derived from available pulp and paper references. Anomalies in the information are attributed to the difficulty of gathering process energy consumption information. Process and component energy consumption figures are typically referred to in industry using specific energy consumption (or energy consumed per mass of product produced). In order to keep the form of the data consistent with previously collected information, specific energy consumption estimates were multiplied by annual estimates of the mass of material produced for the major processing steps. 
As will be discussed in the following section, energy consumption at the component and processes level was found to be extremely inconsistent. Multiple consumptions estimates are given when contradictory information was found. Estimates for a single process sometimes varied by an order of magnitude. It is not known whether incongruities are due to errors in some information, due to differences in definitions of processes, or actual energy efficiency differences.

\subsubsection{Component End Use}

As illustrated in Table 2.5 the paper industry's electric loads are predominantly heavy motors used for pumps, mixing, and cutting. This fact is difficult to deduce from Table 4.1. Pulp and paper references provided little information on characteristics of electric consumption at the component level. The industry is primarily focused on optimizing processes as opposed to equipment. This is probably due to the fact that operating efficiencies of identical equipment used in different processes will be affected by the environment, loading conditions and other factors that change as a function of application.

\subsubsection{Pulp and Paper Processes}

The major paper production processes are pulping, bleaching, paper making, paper drying, and finishing. Of these pulping and the paper machine are the largest consumers of electric energy. The method of pulping plays an important role in characterizing the electric energy use of the pulping process.

Pulp is processed either chemically (Kraft or Sulfite process) or mechanically. While the general energy intensities of the three process are relatively close, the form of energy consumed differs dramatically. Kraft process plants use primarily thermal energy while mechanical pulp process are electric intensive, using as much as four times the electric energy per ton of processed product as the chemical processes. Column one in Table 4.1 shows the estimated specific energy consumption for various types of chemical and mechanical pulping processes. Currently $70 \%$ of pulp mills use a chemical process and $10 \%$ use a mechanical process (the remaining $20 \%$ is attributed to processing recycled paper products). This is reflected in Column 3 of Table 4.1 which shows chemical pulping having a higher annual electric energy consumption even though on a per mass product produced basis it is substantially less. In other words, even though chemical pulping consumes less energy per unit product than mechanical pulping, more paper is produced using chemical resulting in more electric energy being consumed by chemical pulping. However, due to its high yield, environmental benefits, lower capital, raw material, and operating costs of production, thermomechanical pulping is the fastest growing sector of the pulp and paper industry (Burwell 1986). Mechanical pulping electric energy consumption will correspondingly increase with increased use of mechanical pulping processes.

The electric consumption of the paper machine is due primarily to motors which are needed to operate the machine drives, pumps and other rotating devices required for operation. As shown in Table 4.1 the electricity consumption of the paper machine varies as a function of the type of paper product. The variation in energy consumption estimates is attributed to the inconsistent method of accounting for paper machine subprocesses. Not all references attributed the same subprocesses such as sheet formation, pressing, drying, coating, calendaring, and winding to the paper machine process resulting in substantially different energy estimates. 


\subsection{O\&M Issues}

Energy conservation measures typically considered by industry are equipment oriented. Some examples include retrofits, replacement with more efficient devices, fuel switching, and the addition of waste heat recovery devices. While these have certainly proven themselves as valuable methods of reducing energy consumption, another relatively untapped area from which large benefits can be reaped with minimal investment, is improvements to operation and maintenance procedures. Savings can result not only from the identification and correction of poor maintenance procedures but also from the implementation of advanced diagnostic and control technologies.

The amount of energy that can be saved by improving current O\&M procedures is primarily a function of the maintenance techniques being practiced and the equipment and processes that are being maintained. In order to assess the energy-savings potential of improved O\&M in the paper industry it was necessary to identify current industry O\&M practices and the types of process and equipment affected by them.

\subsubsection{General O\&M Techniques}

There are three basic O\&M techniques used by the paper industry; corrective maintenance, preventive maintenance, and predictive maintenance. Corrective maintenance is the practice of waiting for a failure to occur before repairing or replacing a component. It is the oldest and the most commonly practiced method. Because of its "wait until failure occurs" approach, corrective O\&M is the least efficient and most costly method. The high costs are a result of decreases in component lifetime due to continued improper operation, plant shutdowns required for repairs, and increased personnel required to perform the repairs.

A more effective and less costly approach is to search for symptoms indicative of a degradation in performance as opposed to a component failure. This preventative approach can, depending on the complexity of the operation and the amount of funding allocated to O\&M, be worker or computer based. Preventive maintenance has been in use in the pulp and paper industry for over a decade and has proven to be cost effective. A preventive maintenance program initiated at Mid-Eastern Box Manufacturing Company resulted in an increase in production and a reduction in downtime of $10 \%$ (Reidel 1989). A survey of Swedish pulp and paper mills showed that a reduction in downtime of up to $50 \%$ could be attained after the introduction of a preventive maintenance program (Larson 1986). Depending on the situation at the start of a project, costs associated with computerizing maintenance varies from $0.5 \%$ to $4 \%$ of annual maintenance costs for the plant during the project time span.

The state-of-the-art O\&M systems employ predictive maintenance practices. Predictive methods utilize advanced diagnostic and control techniques to anticipate degradation as opposed to evaluating degradation or identifying failure. These methods typically employ remote monitoring and computer diagnostic techniques. Such advanced sensing and control is currently being researched by the paper industry to monitor various paper making processes. The goal of the research is to optimize product yield and quality to process inputs, including energy. In general, these advanced developments are not driven by energy considerations, but energy efficiency usually improves as a by-product. Potential savings through process optimization and advanced control for the electric intensive paper machine has been estimated to be 10\% to 20\% (Mannisto 1986). 
A survey of pulp and paper mills illustrates the diversity in the approach to O\&M. On average, the percentage of personnel assigned to predictive and preventive maintenance falls between $8 \%$ and $20 \%$ of the maintenance work force (Yolton 1988). This indicates that the more effective predictive and preventive methods are not in widespread use but are becoming more accepted as their benefits are more fully understood. It has been estimated that when things are done to reduce maintenance costs, the savings potential is seldom less than a $1 \%$ to $2 \%$ increase in prime quality production output and a 20\% reduction in maintenance costs (Idhammar 1988).

Regardless of which of the previously discussed maintenance approaches are used, the purpose of an O\&M program in a pulp and paper plant remains the same: reduce emergency breakdowns, increase machine reliability and efficiency, and to reduce downtime and overtime with the overall goal of increasing production while decreasing operating costs. While the emphasis is more geared toward minimizing unscheduled outages, energy is wasted during these outages, and more energy is wasted when the plant is forced to operate above capacity to make up for the idle period. In addition, most of the procedures that make equipment and/or process more productive also result in a higher efficiency. In other words making operating and maintenance changes to reduce downtime and increase production will result in increased energy efficiency and thus decreased operating costs.

Prior to the energy crisis in the early seventies, maintenance was often looked upon by management as a necessary nuisance and maintenance expenses were at the bottom of budget priorities. As energy and operating costs have increased, the desire to reduce the number of unscheduled shutdowns and to increase the time between planned shutdowns has elevated the awareness of the importance of maintenance in the daily operation of paper plants. This trend has been compounded by increased environmental restrictions on the industry. The required energy to control environmental effects associated with production techniques may be significant. As a result, existing and proposed environmental standards are playing a significant role in the design of pulp and paper energy programs.

\subsubsection{O\&M Practices in the Pulp and Paper Industry}

A listing of potential electric energy reduction items identified for the pulp and paper industry by Ford, Bacon and Davis is listed in Table 4.2 (Sittig 1977). Of one hundred and thirteen energy conservation opportunities only thirty four are electric in nature. Electric energy represents less than $16 \%$ of the total energy consumed by the paper industry, correspondingly most conservation measures are aimed at decreasing the use of thermal energy (Burwell 1986). Net mill energy savings is the important standard; if savings in one application will be offset by increased energy requirements elsewhere then the application may not be cost effect. It is important to realize that even though this document addresses only electric energy use, the total energy cycle, electrical and thermal, must be considered before pursuing any energy conservation opportunity.

\subsection{O\&M Impacts}

A review of pulp and paper trade papers was conducted to gain insight into the savings potential of operation and maintenance related electric energy conservation opportunities in the paper industry. Most of the literature presented results of specific conservation actions taken at particular plants. It appears that, with the exception of the EADC work, little effort has been made to consolidate 
potential energy savings information. This section will present the information gathered in the literature search and compare it with the EADC pulp and paper information.

Over 100 issues of the paper trade journals, Pulp \& Paper and the Tappi Journal, were examined for articles pertaining to electric savings achievable through O\&M improvements. Very little quantifiable information was found. The majority of the articles pertaining to O\&M issues either discussed the benefits in a very general manner or discussed maintenance impacts for specific equipment. Most of the equipment specific articles were concerned with the maintenance of the paper machine and associated motor drives. This is consistent with the TAG electricity consumption characteristics of the paper industry and with the results of the analysis of the EADC data. Figure 4.1 summarizes the national O\&M conservation potential for the pulp and paper industry previously presented in Figure 3.12. The end-use categories of the DIECO recommendations, which identify over 500 million $\mathrm{kWh} / \mathrm{yr}$ savings, have also been included on the chart.

\subsubsection{The Paper Machine}

The paper machine is one of the most critical elements of the paper manufacturing cycle. The machine operates in a dynamic, constantly changing chemical environment that is prone to mechanical failure. It has been estimated that one minute of downtime for a paper machine causes a marginal loss of $\$ 200$. Is: a single year the loss is typically around $\$ 3$ to $\$ 4$ million for each paper machine with the maintenance and repair costs of this complex device being as high as $3 \%$ to $6 \%$ of the total revenues of a mill (Mattson and Virtanen 1989). In addition to fewer unscheduled downtimes, more time between scheduled downtimes, and less overall downtime, benefits of improved maintenance programs have also included higher quality paper and increased production through faster machine speeds. As a result, insuring proper operation of the paper machine through rigorous and often times advanced maintenance techniques is an industry priority. The payoffs of implementation of such advanced maintenance programs have been documented. For example, in a Norwegian paper mill, after adopting a stringent maintenance program, downtime of paper machines due to technical failures decreased by an average of $3.5 \%$ resulting in a production rise worth nearly $\$ 1.5$ million (Larson 1986).

Several predictive maintenance systems have been developed and implemented in the paper industry to continuously monitor key parameters of the paper machine and provide valuable information used to avoid unexpected shutdowns by assessing actual equipment condition and their probable failure repair date. The following electronic measurements can be made and analyzed in real time: oil flow to the bearings, oil and bearing temperatures, vibration, moisture content of the oil, pressures in oil system, pressure differential across filters, and quantities of seal water in the stuffing boxes of pumps and vacuum pumps (Venalainen 1989).

\subsubsection{Rotating Equipment}

Many of the measurement points mentioned above are directly concerned with or relate to motor operation. In general, the paper industry heavily depends on rotating equipment such as pumps, compressors, drives, crushers, cutters, fans and turbine gears. It employs more rotating equipment per unit of production than any other manufacturing industry (Orlowski 1986). Even though rotating equipment can make up between $30 \%$ to $40 \%$ of the total maintenance budget of a paper plant, less than $10 \%$ of NEMA frame motors in the pulp and paper industry serve 100,000 hours before their 
first failure. In fact, many motors fail in less than 25,000 hours (approximately three years) (Orlowski 1986). With motor failure being the leading cause of lost time for the paper machine, proper maintenance of motors has become a priority of the paper industry, not only to decrease downtime due to failure but also to decrease operating costs. A 50\% cut in the maintenance budget will enhance a typical paper company's bottom line by $\$ 20$ to $\$ 30$ million and improve earnings by 10\% to 13\% (Orlowski 1986). These estimates do not include downtime, production loss or disruptions. The implementation of even a simple computer part and maintenance tracking system can result in substantial savings. Such a preventive maintenance system employed at a Union Camp paper mill reduced motor repair costs by $30 \%$ and downtime between $50 \%$ and $60 \%$ (Cortes 1988).

Many of the advanced motor maintenance systems used in paper mills monitor the wear of bearings. Bearings are often times the limiting factor determining the reliability and lifetime of rotating equipment. Less than $10 \%$ of all bearings reach or exceed their minimum life expectancy and $30 \%$ to $40 \%$ of all motor failures in the paper industry are due to bearings (Orlowski 1986). A common method of monitoring bearing wear is through the use of vibrational analysis. Using bearing failure signatures which indicate the current condition of the bearings, a paper machine was repaired before failure resulting in a savings of $\$ 72,016$ from the previous failure repair cost of $\$ 118,110$. This preventive repair approach resulted in a savings of 61\% (Orlowski 1986). Another method of improving bearing operation is to isolate them from the harsh paper mill environment and use highperformance synthetic lubricants. Broad-scale testing of this approach indicates a $60 \%$ to $70 \%$ reduction in catastrophic failures. These results indicate a possible $50 \%$ recuction in rotating equipment maintenance and a $230 \%$ return on investment for conversion to better bearing maintenance methods (Orlowski 1986).

Maintaining proper seals is also an important issue in insuring the optimal operation of rotating equipment. Most of the rotating machinery require sealing to prevent loss of product or excessive dilution by leaking seals. Only $5 \%$ of all mechanical seals in a typical pulp and paper mill achieve normal life. Of the $95 \%$ that fail prematurely, $15 \%$ fail due to application error, $20 \%$ to installation error and 60\% to operation error (Bosar and Krogel 1988). Because sealing failures do not have the same dramatic effect on operations as bearing failures (i.e., do not typically result in a forced shutdown), their maintenance has been to some extent neglected. This is indicative of an industry which is often more focused on reducing downtime than on improving operating efficiency.

From the literature reviewed, it appears that most of the emphasis in the pulp and paper industry is on reducing downtime; however, some cooperative efforts have been made between the industry and utilities to examine the potential of increasing the electrical efficiency of equipment. For example, Boise Cascade and Pacific Power and Light Co. examined the potential efficiency improvements in pumping systems. The results of the study indicated that energy savings were available even in recently designed and installed pumping systems. Trimming the size of the impellers was found to be the most expedient method of improving the electrical efficiency of the pumping systems. This procedure led to a reduction in annual cost of electricity of $2.5 \%$ to $8.2 \%$ with a simple payback period of 5.2 to 15.7 months (assuming a $\$ 2,500$ cost to trim each impeller) (Gault and Rucker 1986). In a similar study, trimming the impeller of oversized induced-draft fans required in a pulp mill's lime kiln, resulted in an annual energy savings of $\$ 110,000$ (370-hp savings) for a cost of $\$ 35,000$ (Perry 1989). 


\subsection{Conclusions}

Generalized process information, such as that found in the IMIS database, does a poor job of characterizing process energy consumption in the pulp and paper industry. Energy consumption estimates made within the industry give a better feel for how electric energy is consumed as a function of process. However, process consumption estimates can vary dramatically because of the variety of types of paper plants, process utilized, size, and operating methods. Because the paper industry tends to categorize its equipment as a function of the process, overall component electricity consumption data is better characterized in the generalized references discussed in Section 3.0.

Energy conservation opportunities developed specifically for the pulp and paper industry are almost identical to the generic DIECO recommendations. This was to be expected since O\&M procedures are component driven. While processes differ drastically in the various manufacturing industries, the equipment used in the processes are basically the same. In other words, the approach to O\&M is universal across the manufacturing sector. It can be concluded that the analysis using the EADC and DIECO information to determine the potential electricity savings addresses most of the conservation opportunities available to the respective industries.

The pulp and paper industry is aware of the importance of operation and maintenance and has already adopted some of the most advanced housekeeping methods, however, there still remains substantial opportunity for increasing the electrical efficiency of the industry. The industry has the third largest potential for electric energy savings through improvements in O\&M procedures at approximately 15,000 million $\mathrm{kWh}$ annually (refer to Figure 3.14 ). This study has shown that the primary savings will be achieved through improved maintenance of motor drives.

Even though the driving factor in the industry appears to be reducing downtime, this study shows that the awareness of the potential for reducing operating costs through reduced electric consumption within the paper industry appears to be growing. Only with this realization can the potential electric energy savings in the industry be achieved. 
Un 
Table 4.1. Process and Component Energy Consumption

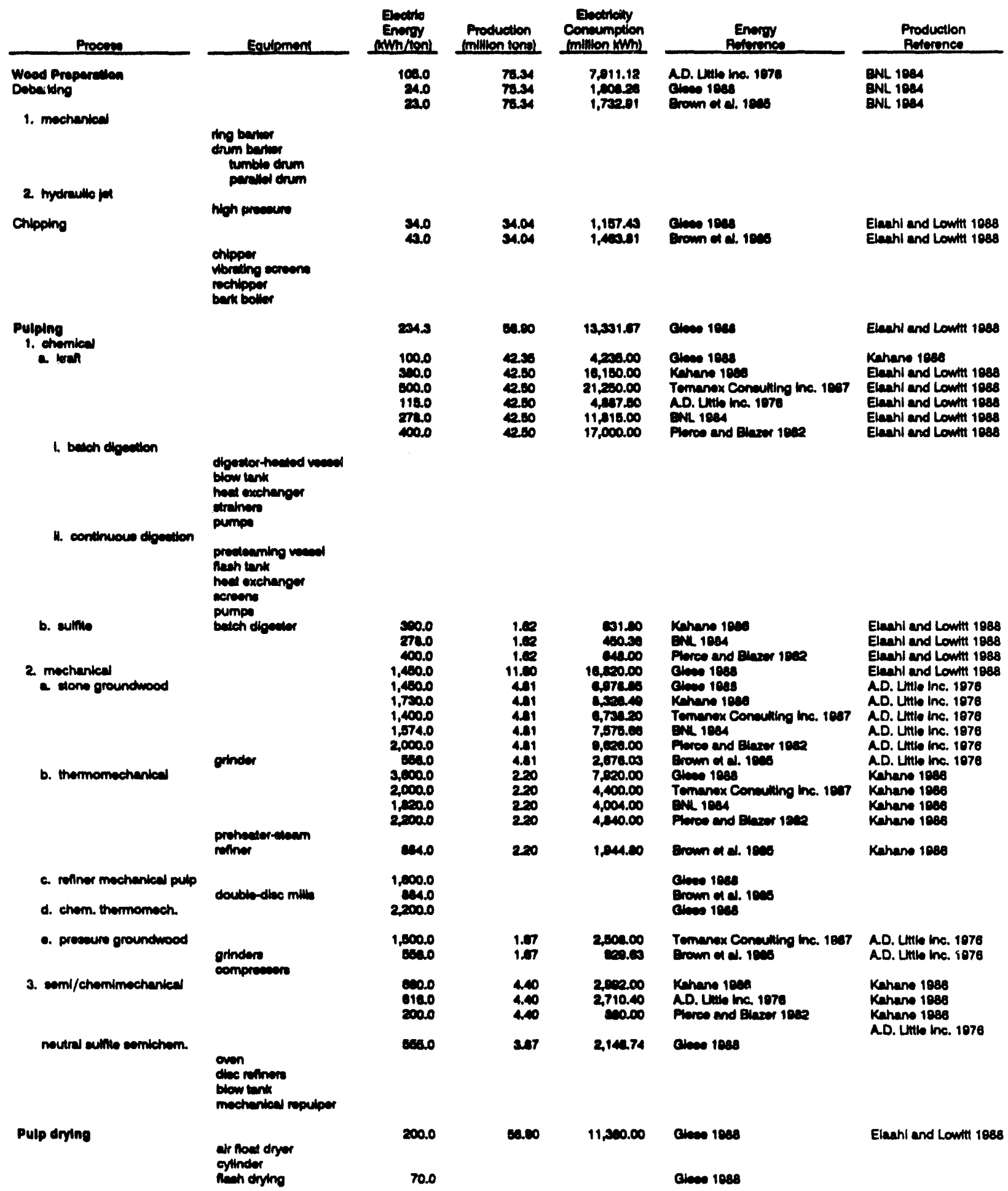


Table 4.1. (contd)

\begin{tabular}{|c|c|c|c|c|c|c|}
\hline Proceres & Equloment & $\begin{array}{l}\text { Enctile } \\
\text { Energy } \\
\text { enwh tion) }\end{array}$ & $\begin{array}{l}\text { Production } \\
\text { Imillion tonel }\end{array}$ & 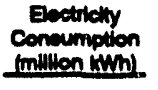 & $\begin{array}{c}\text { Energy } \\
\text { Pedenence }\end{array}$ & $\begin{array}{l}\text { Produetion } \\
\text { Rederences }\end{array}$ \\
\hline $\begin{array}{l}\text { Caustolzino } \\
\text { Weoning }\end{array}$ & & $\begin{array}{l}\infty .0 \\
11.7 \\
60.0 \\
200\end{array}$ & $\begin{array}{l}20.0 \\
8000 \\
600\end{array}$ & $\begin{array}{r}241.00 \\
24.100 \\
4,11270\end{array}$ & 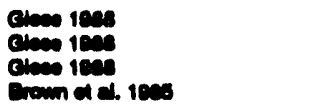 & 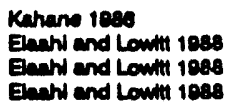 \\
\hline 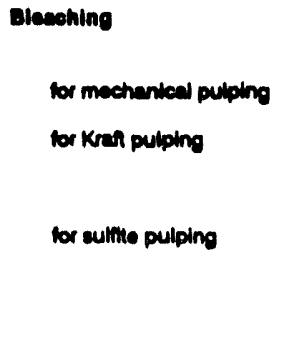 & 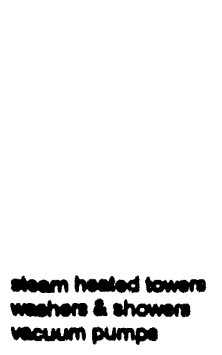 & $\begin{array}{l}002 \\
00.0 \\
117.0 \\
00.0 \\
49.0 \\
000.0 \\
10.0 \\
128.0 \\
117.0 \\
100.0 \\
117.0\end{array}$ & 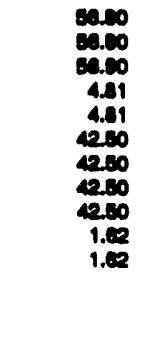 & 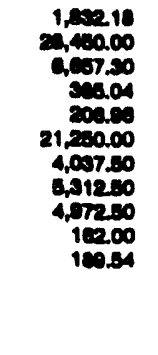 & 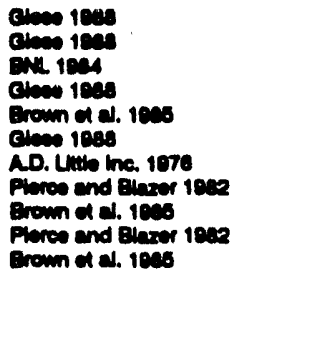 & 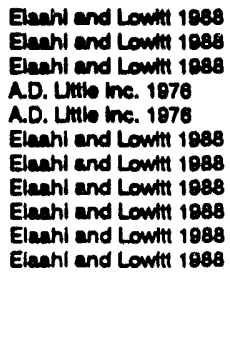 \\
\hline $\begin{array}{l}\text { 2. chomical addition } \\
\text { blending }\end{array}$ & $\begin{array}{l}\text { moulper (mech.) } \\
\text { conical } \\
\text { inglo-dice } \\
\text { double-diece } \\
\text { pumpe }\end{array}$ & $\begin{array}{r}00.0 \\
+20.0 \\
340.0 \\
240.0 \\
20.0\end{array}$ & & & 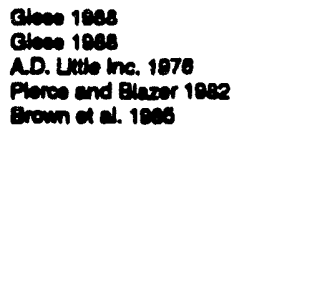 & \\
\hline 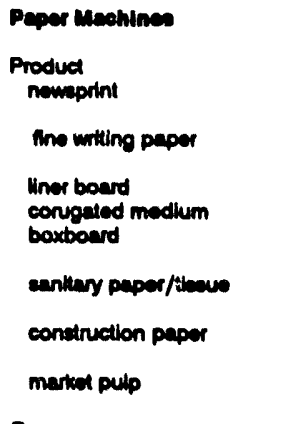 & & $\begin{array}{l}100.4 \\
800.0 \\
400.0 \\
300.0 \\
800.0 \\
300.0 \\
700.0 \\
300.0 \\
300.0 \\
370.0 \\
600.0 \\
375.0 \\
700.0 \\
400.0 \\
200.0 \\
100.0 \\
200.0\end{array}$ & $\begin{array}{l}7.34 \\
7.34 \\
7.34 \\
0.01 \\
0.01 \\
0.01 \\
0.01 \\
0.00 \\
0.00 \\
0.01 \\
0.01 \\
0.01 \\
0.01 \\
0.01 \\
0.01 \\
0.00 \\
0.00\end{array}$ & 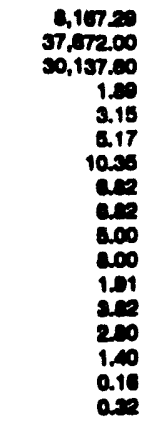 & 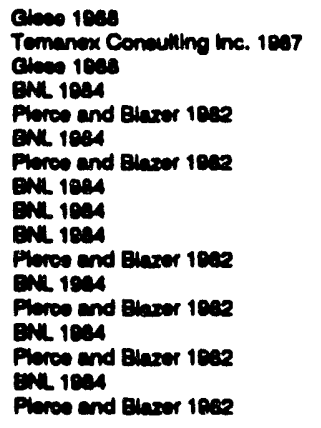 & 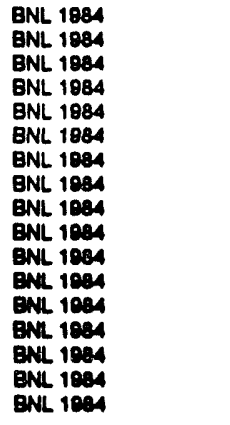 \\
\hline \multirow{2}{*}{$\begin{array}{l}\text { Procoswes } \\
\text { 1. Paper mechine } \\
\text { a theot formation }\end{array}$} & & & & & & \\
\hline & 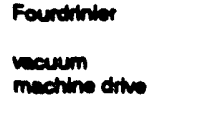 & $\begin{array}{l}1700 \\
140.0 \\
70.0 \\
120.0\end{array}$ & $\begin{array}{l}7034 \\
7034 \\
7034\end{array}$ & $\begin{array}{r}12,160200 \\
11,000202 \\
8,000.20 \\
0,418.00\end{array}$ & 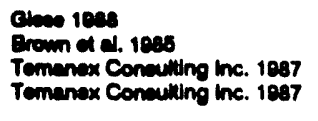 & $\begin{array}{l}\text { ENL 1084 } \\
\text { ENL 1084 } \\
\text { BNL 1084 } \\
\text { BNL 1984 }\end{array}$ \\
\hline c. drying & $\begin{array}{l}\text { conted dryer } \\
\text { competion dryer } \\
\text { nodletion dryer } \\
\text { mlerowew } \\
\text { infrared } \\
\text { impulas }\end{array}$ & $\begin{array}{l}180.0 \\
100.0 \\
170.0 \\
80.0 \\
80.0\end{array}$ & $\begin{array}{l}76.34 \\
76.34 \\
7.24 \\
70.34 \\
70.24\end{array}$ & $\begin{array}{r}11,301.00 \\
7,834.40 \\
12,180.20 \\
2,701.20 \\
4,2000\end{array}$ & 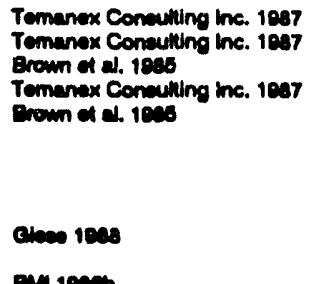 & $\begin{array}{l}\text { BNL } 1984 \\
\text { BNL } 1984 \\
\text { BNL 1984 } \\
\text { BNL 1984 } \\
\text { BNL 1884 }\end{array}$ \\
\hline d. costing & al binse conerer & & & 606.10 & Ean 10acos & \\
\hline f. winder & (1000 & & & & & \\
\hline
\end{tabular}


Table 4.1. (contd)

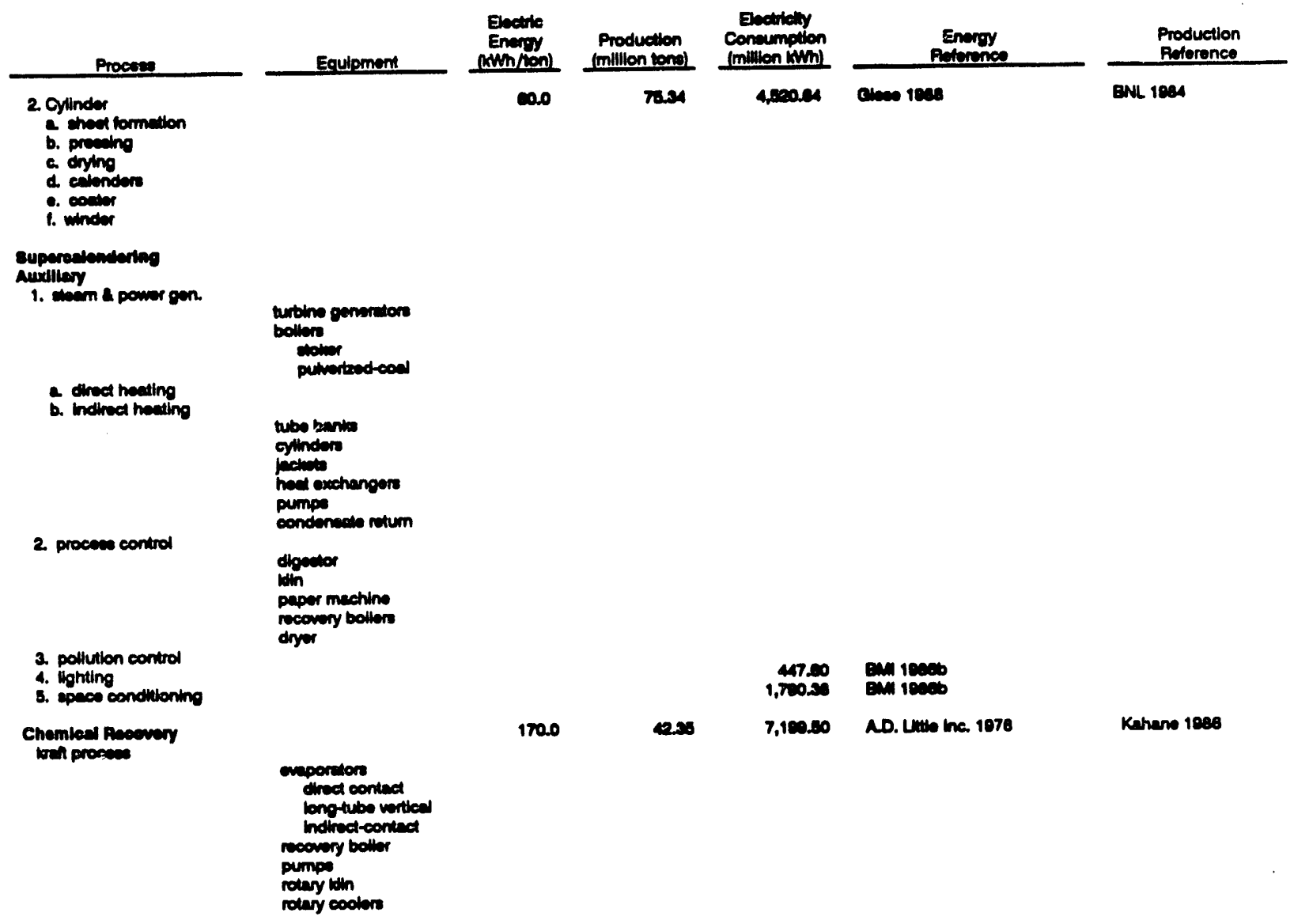


Table 4.2. Pulp and Paper Energy Conservation Opportunities

Classification

General Mill -

Compressed Air

Systems

General Mill Insulation
Energy Conservation Opportunity

- Reduce wasteful use of compressed air by O\&M personnel
- Reevaluate insulation installed using past low-energy cost criteria, and install additional insulation where justified on a cost versus energy-saving basis

- Reevaluate piping, equipment and vessels that are not presently insulated, and install additional insulation where justified on a cost versus savings basis

General Mill Maintenance

General Mill Electrical

Pulp Mill Wood Receiving and Handling

Pulp Mill Bleaching
- Repair compressed air leaks

- Repair water and process leaks

- Maintain pump and agitator seals in good condition to reduce wastage

- Repair or replace damaged insulation

- Increase maintenance planning and preventive maintenance

- Match induction motor horsepower as closely as possible to load. Induction motors operate at maximum efficiency and power factor at full load

- Install photocell or time switch on outdoor lights

- Use high pressure sodium lights in place of incandescent or mercury vapor, except in office areas, low ceiling areas, and emergency lighting

- Use "spot" lighting and avoid high general area lighting as much as possible

- Transfer chips and bark by belt rather than pneumatic conveyor

- Operate bleach plant with pulp at maximum feasible consistency to reduce pumping horsepower and heating system consumption

- Utilize computer control to optimize the operation for maximum energy and chemical consumption 
Table 4.2. (contd)

Classification

Power Plant -

Electrical

Generation \&

Distribution

Power Plant -

Black Liquor

Evaporators

Paper Mill -

Stock

Preparation

Paper Mill -

Paper Machine

Paper Machine Building Air

System
Energy Conservation Opportunity

- Minimize purchased electrical power by use of automatic purchased power/back-pressure power/selective load shedding control

- Maximize condenser efficiency by maintaining cleanliness of tubes

- Maximize condenser efficiency by maintaining steam jet ejectors of vacuum pumps in efficient manner

- Maximize condenser efficiency by minimizing air leakage into vacuum system

- Maximize station efficiency by computer control of multiple generating units for most favorable distribution of load

- Maintain cleanliness of condenser tubes to obtain highest vacuum

- Maintain condenser air-ejector equipment to obtain highest vacuum

- Minimize air leakage into vacuum system

- Maintain condenser steam jet ejectors in efficient condition by testing, by inspection during shutdowns, and replacement of worn jets when indicated

- Operate condenser steam jet ejectors at proper pressure for maximum efficiency

- Design/operate saveall systems to produce wash water of sufficient cleanliness and reliability for general reuse in stock preparation and paper mill (e.g., fourdrineir showers, saveall showers, headbox showers, dilution mechanical pulping operations, etc.)

- Use variable speed from fan pump drive on multigrade machine

- Evaluate and optimize pressure drop across stock cleaners and screens

- Optimize press efficiency

- Optimize paper machine hood system

- Use computer to control

- Operate air makeup and exhaust units only when necessary

- Provide building insulation to reduce heating and ventilation requirements 


\subsection{Conclusions and Recommendations}

The results of this analysis identify a significant electric resource potential available through O\&M activities both nationally and for the Pacific Northwest. This section will focus on the results for the Pacific Northwest. The overall potential in the Pacific Northwest identified in this study range from a low of 4,903 million $\mathrm{kWh} / \mathrm{yr}(559.7 \mathrm{aMW})$, from the EADC database analysis, to as nuch as 7,414 million $\mathrm{kWh} / \mathrm{yr}(846.7 \mathrm{aMW})$, from the general literature review (Table 3.1, Smith 1978).

The equipment category with the largest energy-savings potential identified in this study is Air Compressors and Compressed Air Systems, followed closely by Motors and Motor Drive Systems. Table 5.1 identifies the Pacific Northwest energy-savings potential by major DIECO end-use category from the EADC database. The specific O\&M measure with the largest potential is repairing leaks in compressed air lines (DIECO 3231). The ten industrial O\&M measures with the largest potential from the EADC database are listed in Table 5.2.

Overall, the results from the EADC database analysis are not fairly consistent with the results of the general literature review. In a case-by-case comparison, the estimated potential energy savings resulting from compressed air systems is 1,482 million $\mathrm{kWh} / \mathrm{yr}(169.2 \mathrm{aMW})$ from the EADC analysis and 416 million $\mathrm{kWh} / \mathrm{yr}(47.5 \mathrm{aMW})$ from the general literature review (Table 3.1, Singh et al. 1990). In the specific measure, repairing compressed air leaks, the potential energy savings is 1,040 million $\mathrm{kWh} / \mathrm{yr}$ (118.7 aMW) from the EADC analysis compared to between 165 and 908 million $\mathrm{kWh} / \mathrm{yr}(18.8$ and $103.7 \mathrm{aMW}$ ) from the general literature review (Table 3.1, Singh et al. 1990 and Patel 1991). Table 5.3 compares the findings of the general literature review to the EADC analysis for those measures which can be easily related.

The industry with the largest energy-savings potential in the Pacific Northwest through O\&M activities is Paper and Allied Products (SIC 26). This can be readily seen in Figure 3.18. The primary aluminum industry (SIC 3334), the largest energy consumer in the Pacific Northwest, was excluded from the Pacific Northwest application of the EADC analysis and therefore could not be included in the study. The O\&M resource potential within the primary aluminum industry is an unknown and merits further analysis.

The recommendation based on the results of this study is to proceed with the additional tasks to this project to verify the O\&M electric energy resource potential of air compressors and compressed air systems. A second alternative is motors and motor drive systems. Both of these categories offer significant energy-savings potential that could be readily achieved and maintained. 
Table 5.1. Summary of Pacific Northwest Industrial O\&M Energy-Savings Potential, 1990

\section{Major DIECO End-Use Category}

Air compressors and compressed-air systems

Motors and motor drive systems

Lighting

HVAC systems

Equipment scheduling and control systems

Insulation

Ventilation systems

Refrigeration systems

Other miscellaneous opportunities Total
PNW Potential

(million $\mathrm{kWh} / \mathrm{yr}$ )

$1,482.37$

$1,129.63$

813.09

449.44

431.35

183.23

124.64

78.47

211.20

$4,903.42$
PNW Potential (aMW)

169.2

129.0

92.8

51.3

49.2

20.9

14.2

9.0

24.1

559.8

(a) 1 aMW $=8.76$ million $\mathrm{kWh} / \mathrm{yr}$

Table 5.2. Top Ten Industrial O\&M Energy-Saving Measures in the Pacific Northwest, 1990

\begin{tabular}{|c|c|c|c|c|}
\hline DIECO & DIECO Deacription & $\begin{array}{c}\text { End-Use } \\
\text { Equipment }\end{array}$ & $\begin{array}{c}\text { PNW Potential } \\
\text { (million } \mathbf{k W h} / \mathbf{y r} \text { ) }\end{array}$ & $\begin{array}{l}\text { PNW Potential } \\
\text { (aMW) }\end{array}$ \\
\hline 3231 & Eliminate leaks in lines and valves carrying compreseod-air or other genes & Air Compreason & $1,040.46$ & 118.8 \\
\hline 5122 & Improve hubrication practices for molor-driven equipmeat & Moton & 613.34 & 70.0 \\
\hline 5355 & Une energy-efficient belts and other improved mechaniema & Moton & 491.69 & 56.1 \\
\hline 4112 & Reduce operating time of equipment to the minimum required/inmtall timen & Controle & 278.81 & 31.8 \\
\hline 6121 & Inetall timen or motion seneon on liule wed lights or initinte achodule & Lighting & 253.62 & 29.0 \\
\hline 6111 & Disconnect lighting fixtures, delamp, or uec lower output hmpe for min. light & Lighting & 248.16 & 28.3 \\
\hline 3221 & Install comprewer air intake in coolest location & Air Compresenon & 190.97 & 21.8 \\
\hline 3211 & Reduce the preasure of compresed air aystem to the minimum required & Air Compreason & 175.13 & 20.0 \\
\hline 5511 & Inoulate tunks, veacels, lines, and procens equipment & Inoulation & 166.35 & 19.0 \\
\hline 6244 & Invtall or use timen or thermoutul for epece conditioning & HVAC & 146.79 & 16.8 \\
\hline
\end{tabular}


Table 5.3. Comparison of O\&M Findings for the Pacific Northwest

EADC Other Sources

Potential Potential

O\&M Measure

(million $\mathrm{kWh} / \mathrm{yr}) \quad$ (million $\mathrm{kWh} / \mathrm{yr}$ )

General Air Compressors and Compressed Air Systems Eliminate Leaks in Compressed Air Systems

Relocate Compressed Air Intake to Cool Location

General HVAC Systems

Improve Lubrication Practices

Use Energy-Efficient Belts
1,482

1,040

191

449

613

492
416

165 to 908

116

522

238 to 4,339

346 to 487 


\subsection{References}

Argonne National Laboratory. 1980. Classification and Evaluation of Electric Motors and Pumps. DOE/TIC-11339, Argonne National Laboratory, Argonne, Illinois.

Arthur D. Little, Inc. 1976. Environmental Considerations of Selected Energy Conserving Manufacturing Process Options: Vol. V. Pulp and Paper Industry Report. PB-264 271, National Technical Information Service, Springfield, Virginia.

Baechler, M.C., K.F. Gygi, and P.L. Hendrickson. 1992. Potential Environmental Effects of Energy Conservation Measures in Northwest Industries. PNL-8015, Pacific Northwest Laboratory, Richland, Washington.

Battelle - Columbus Division (BMI). 1986a. Industrial End-Use Planning Methodology (INDEPTH): Demonstration of Design, Interim Report. EPRI EM-4988, Vol. 3, Project 2217-1, Interim Report, Electrical Power Research Institute, Palo Alto, California.

Battelle - Columbus Division (BMI). 1986b. Industrial Market Information System (IMIS) Database, Version 1.0. CU-2029, Electric Power Research Institute, Palo Alto, California.

Bosar, G.J., and E.J. Krogel. March 1988. "Proper Troubleshooting Techniques Can Extend Life of Mechanical Seals." Pulp \& Paper 62(3):155-161.

Brookhaven National Laboratory (BNL). 1984. Industrial Process Models of Electricity Demand Vol. 2: The Pulp and Paper Industry. EPRI EA-3507, Electrical Power Research Institute, Palo Alto, California.

Brown, H.L., B.B. Hamel, and B.A. Hedman. 1985. Energy Analysis of 108 Industrial Processes. DOE/ET/13124-T2, Drexel University, Philadelphia.

Burwell, C.C. 1986. Roles of Electricity: Pulp and Paper. EPRI EU-3008-9-86, Electric Power Research Institute, Palo Alto, California.

Cortes, T. December 1988. "Use of Computer Tracking System Reduces Failures at Union Camp." Pulp \& Paper 62(13):53-55.

Decision Analysis Corporation of Virginia. 1990. Energy Consumption Patterns in the Manufacturing Sector. Contract No. DE-AC01-97EI19801, Task 110, Vienna, Virginia.

Elaahi, A., and H.E. Lowitt. 1988. The U.S. Pulp and Paper Industry: An Energy Perspective. DOE/RL/01830-T57, Energetics Inc., Washington D.C.

Fuchs, S.J. 1993. Complete Building Equipment Maintenance Desk Book: Supplement, 2nd ed. Prentice Hall, Englewood Cliffs, New Jersey. 
Gault, T., and K. Rucker. September 1986. "Reduction of Electrical Consumption in Paper Mill Pumping Systems." Tappi Journal 69(9):86-90.

Giese, R.D. 1988. Scoping Study: Pulp and Paper Industry. RP2782-3, Giese \& Associates, Seattle, Washington for Electric Power Kesearch Institute, Palo Alto, California.

Glasser, C. 1992. "Industrial Energy Auditing: An Opportunity for Improving Energy Efficiency and Industrial Competitiveness." In Proceedings of the Fourteenth National Industrial Energy Technology Conference, pp. 26-30. April 22-23, 1992, Houston. Texas A\&M University, College Station, Texas.

Ibáñez, P. 1978. "Electromechanical Energy." Chapter 11 in Efficient Electricity Use: A Reference Book on Energy Management for Engineers, Architects, Planners, and Managers. 2nd ed., ed. C.B. Smith, pp. 369-410. EPRI EC-127, Project 211, Pergamon Press, New York.

Idhammar, C. September 1988. "Maintenance Myths." Pulp \& Paper 62(9):259.

Ivanick, F.M. October 1979. "Proper Lubrication Supports Energy Management." Heating/Piping/Air Conditioning 51(10):171-174.

Kahane, A. 1986. Industrial Electrification: Case Studies of Four Industries; Steel, Paper, Cement and Motor Vehicles Production in the U.S. and Japan. RP-2345-42-00, Lawrence Berkeley Laboratory (LBL), Tokyo, Japan for EPRI, Palo Alto, California.

Larson, A.S. September 1986. "Preventive Maintenance Program Lifts Norwegian Mill's Availability." Pulp \& Paper 60(9):74-77.

Lewis, D.L. 1991. "Turning Rust into Gold: Planned Facility Maintenance." Public Administration Review 51(6):494-502.

Lovins, A.B., J. Neymark, T. Flanigan, P.B. Kiernan, B. Bancroft, and M. Shepard. 1989. The State of the Art: Drivepower. Competitek-Rocky Mountain Institute, Snowmass, Colorado.

Mannisto, H. August 1986. "Who Can Afford to Save Energy." Tappi Journal 69(8):54-58.

Mattson, R., and S. Virtanen. June 1989. "Reliability Maintenance Can Reduce Failure Frequency and Downtime." Pulp \& Paper 63(6):150-154.

McHugh, J.R., and C.B. Winn. 1992. User's Manual for The Energy Conservation CD-ROM. Colorado State University, Fort Collins, Colorado.

Nadel, S., M. Shepard, S. Greenberg, G. Katz, and A.T. deAlmeida. 1991. Energy-Efficient Motor Systems: A Handbook on Technology, Programs, and Policy Opportunities. American Council for an Energy Efficient Economy, Washington D.C.

Neal, L. May/June 1992. "Air Conditioner Efficiency in the Real World." Home Energy, pp. 3239. 
Northwest Economic Associates. 1986. Marketing Electricity to Industrial Customers - A Study of Pacific Northwest Industries. DOE/BP 36696-1, Bonneville Power Administration, Portland, Oregon.

Orlowski, D. September 1986. "Maintenance Can Prevent Most Motor Failures by Sealing Bearings." Pulp \& Paper 60(9):106-109.

Patel, J.R. 1991. "Case Study: Energy Conservation - A Continual Process at Defense Contractor's Manufacturing Facility." Energy Engineering 88(4):50-60.

Perry, R.E. June 1989. "Lime Kiln Energy Conservation, Have We Forgotten the I.D. Fan?" Tappi Journal 72(6):243-246.

Pierce, B.L., and C. Balzer. 1982. Study of Baseline Energy Requirements of the Pulp and Paper Industry in the Bonneville Power Administration Service Area from 1980 to 2000, Final Report. BNL-51604, Brookhaven National Laboratory (BNL) Associated Universities, Cambridge, Massachusetts.

PPX Industrial Fluids Inc. December 1992. "Additives Improve Lubricant Performance." Power 136(12):26.

Reidel, C. 1989. "Mid-Eastern Box Uses Maintenance Software to Increase Productivity." Pulp \& Paper 63(13): 102.

Resource Dynamics Corporation. 1992a. Electrotechnology Reference Guide, Revision 2. EPRI TR-101021, Project 2613-10, Electrical Power Research Institute, Palo Alto, California.

Resource Dynamics Corporation. 1992b. Electric Motors: Markets, Trends, and Applications. EPRI TR-100423, Project 2613-10, Electrical Power Research Institute, Palo Alto, California.

Resource Dynamics Corporation and Battelle - Columbus Division. 1988. TAG: Technical Assessment Guide, Volume 2: Electricity End-Use, Part 3: Industrial Electricity Use-1987. EPRI P-4463-SR, Electrical Power Research Institute, Palo Alto, California.

Singh, H., A. Kapur, and P. Rojeski. 1990. "Energy Conservation Potential in Compressed Air Systems." Strategi Planning and Energy Management 9(3):10-28.

Sittig, M. 1977. Pulp and Paper Manufacture: Energy Conservation and Pollution Prevention. Noyes Data Corporation, Park Ridge, New Jersey.

Smith, C.B. 1978. Efficient Electricity Use: A Reference Book on Energy Management for Engineers, Architects, Planners, and Managers. 2nd ed. EPRI EC-127, Project 211, Pergamon Press, New York.

Synergic Resources Corporation. 1987. Energy-Use Patterns and Indicators, Volume 1: Summary. EPRI EM-5126, Project 1940-16, Electric Power Research Institute, Palo Alto, California. 
Temanex Consulting Inc. 1987. Technoeconomic Trends Favoring Increased Electrical Demand by the Pulp and Paper Industry - A Status Report. CEA No. 623 U 572, North Vancouver, British Columbia.

Venalainen, E. March 1989. "Continuous Electronic Monitoring of Oil Flows, Bearing Oil Temperatures, and Other Parameters of Machinery." Tappi Journal 72(3):65-71.

Weaver, M. January 16, 1984. "Employee Plan Helps Firm Cut Elec. 29\%." Energy User News, p. 8.

Yolton, J.R. August 1988. "Applications of Predictive Maintenance Technology." Focus on Predictive Maintenance, pp. 17-20. 


\section{Distribution}

No. of

Copies

Offsite

12 DOE/Office of Scientific and Technical Information

J. W. James

U.S. Department of Energy

Seattle Support Office

Energy Technologies Division

800 Fifth Avenue, Suite 3950

Seattle, WA 98104

3 K. Vischer

Bonneville Power Administration

P.O. Box 3621, RMID

905 NE 11th Avenue

Portland, OR 97232

M. W. Kendall

Conservation Resources Division

Oregon Department of Energy

625 Marion Street, N.E.

Salem, OR 97310-0001

G. E. Mitchell

Portland General Electric

Energy Resource Group

7895 SW Mohawk Street

Tualatin, OR 97062

G. Wheeler

Professor and Director

Energy Analysis and Diagnostic Center

Oregon State University

Department of Mechanical Engineering

Batcheller Hall 344

Corvallis, OR 97331-2405
No. of

Copies

Onsite

DOE Richland Field Office

D. D. Green

22 Pacific Northwest Laboratory

K. L. Gaustad

C. H. Imhoff

S. A. Parker (10)

W. F. Sandusky

R. F. Szydlowski

W. M. Warwick

D. W. Winiarski

Publishing Coordination

Technical Report Files (5)
$\mathrm{K} 5-20$

K8-54

K5-08

K5-06

K5-08

PORTL

K5-08

K1-06

P8-55 

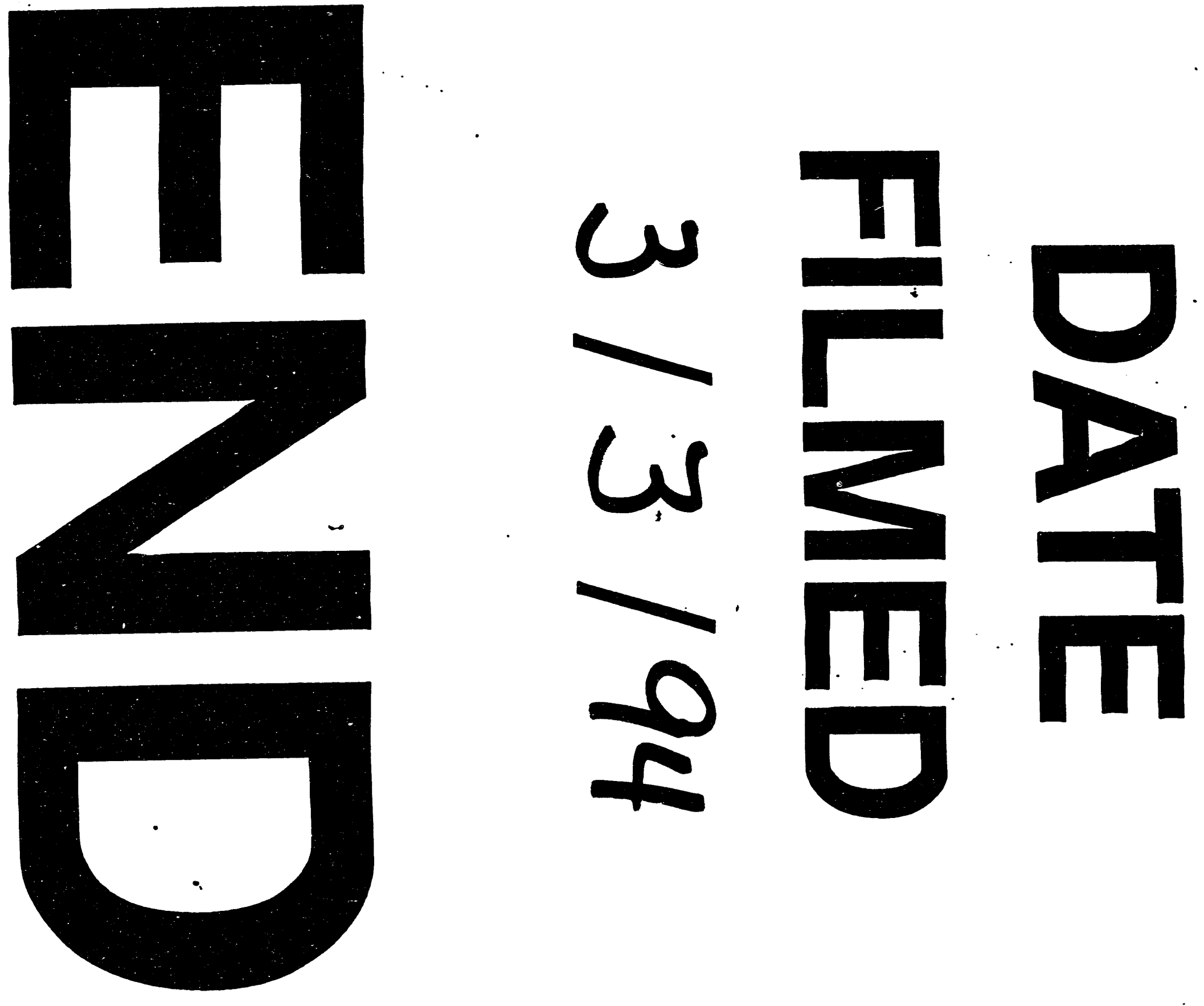
